\title{
Final Technology Report for D-Area Oil Seepage Basin Bioventing Optimization Test, Environmental Restoration Support
}

J. C. Radway, K. H. Lombard, and T. C. Hazen

Environmental Biotechnology Section

Environmental Science \& Technology Department

Savannah River Technology Center

Westinghouse Savannah River Company

Bldg. 704-8T (TNX)

Aiken, SC 29808

Phone (803) 557-7095

Fax (803) 557-7223

Derivative Classifier

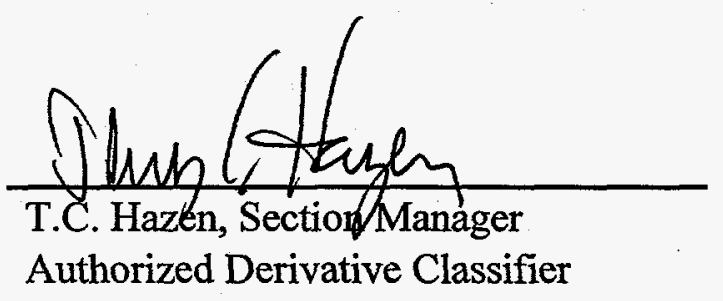




\section{DISCLAIMER}

This report was prepared as an account of work sponsored by an agency of the United States Government. Neither the United States Government nor any agency thereof, nor any of their employees, makes any warranty, express or implied, or assumes any legal liability or responsibility for the accuracy, completeness, or usefulness of any information, apparatus, product, or process disclosed, or represents that its use would not infringe privately owned rights. Reference herein to any specific commercial product, process, or service by trade name, trademark, manufacturer, or otherwise does not necessarily constitute or imply its endorsement, recommendation, or favoring by the United States Government or any agency thereof. The views and opinions of authors expressed herein do not necessarily state or reflect those of the United States Government or any agency thereof.

This report has been reproduced directly from the best available copy.

Available to DOE and DOE contractors from the Office of Scientific and Technical Information, P.O. Box 62, Oak Ridge, TN 37831; prices available from (615) 576-8401.

Available to the public from the National Technical Information Service, U.S. Department of Commerce; 5285 Port Royal Road, Springfield, VA 22161. 


\section{DISCLAMMIER}

Portions of this document may be illegible in electronic image products. Images are produced from the best available original document. 


\section{Final Technology Report for D-Area Oil Seepage Basin Bioventing Optimization Test, Environmental Restoration Support}

J. C. Radway, K. H. Lombard, and T. C. Hazen

Environmental Biotechnology Section

Environmental Science \& Technology Department

Savannah River Technology Center

Westinghouse Savannah River Company

Bldg. 704-8T (TNX)

Aiken, SC 29808

Phone (803) 557-7095

Fax (803) 557-7223

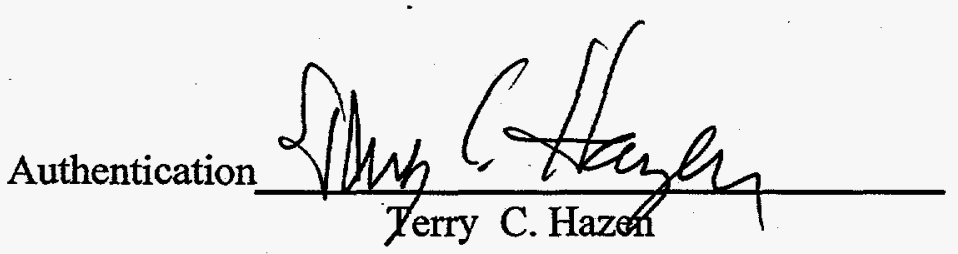

Prepared for the U.S. Department of Energy under Contract No. DE-AC09-96SR18500 
D-Area Oil Seepage Basin

In Situ Bioremediation Optimization Test

WSRC-MS-96-0797, Rev. 0

Final Report

Jan. 24, 1997

\section{Executive Summary}

One method proposed for the cleanup of the D-Area Oil Seepage Basin was in situ bioremediation (bioventing), involving the introduction of air and gaseous nutrients to stimulate contaminant degradation by naturally occurring microorganisms. To test the feasibility of this approach, a bioventing system was installed at the site for use in optimization testing by the Environmental Biotechnology Section of the Savannah River Technology Center. During the interim action, two horizontal wells for a bioventing remediation system were installed eight feet below average basin grade. Nine piezometers were also installed. In September of 1996, a generator, regenerative blower, gas cylinder station, and associated piping and nutrient injection equipment were installed at the site and testing was begun. After baseline characterization of microbial activity and contaminant degradation at the site was completed, four injection campaigns were carried out. These consisted of 1) air alone, 2) air plus triethylphosphate (TEP), 3) air plus nitrous oxide, and 4) air plus methane. This report describes results of these tests, together with conclusions and recommendations for further remediation of the site.

Natural biodegradation rates are high. Oxygen, carbon dioxide, and methane levels in soil gas indicate substantial levels of baseline microbial activity. Oxygen is used by indigenous microbes for biodegradation of organics via respiration and hence is depleted in the soil gas and water from areas with high contamination. Carbon dioxide is elevated in contaminated areas (the biodegradation of organics produces large amounts of carbon dioxide). High concentrations of methane, which is produced by microbes via fermentation once the oxygen has been depleted, are found at the most contaminated areas of this site. Groundwater measurements also indicated that substantial levels of natural contaminant biodegradation occurred prior to air injection. This was evidenced by an observed decline in chlorinated solvent levels to below detection limits during the baseline monitoring period. Both chloride and sulfate levels were elevated, especially in downgradient wells. Chloride is produced as an end-product of biodegradation of chlorinated solvents, while the presence of sulfate is attributed to microbial degradation of petroleum compounds. An increase in redox potential and decrease in conductivity in downgradient groundwater over the course of the study suggests that microbial activity may have reduced the mobility of metal contaminants emanating from the basin. Groundwater samples from the area were found to contain moderate numbers of bacteria.

During air injection, rates of PCE and possibly TCE degradation in the soil of the basin increased, as shown by soil gas measurements. Analysis of soil surface emissions indicated that removal of VOC's was not simply the result of air stripping. PCE degradation rates averaged 1.7 $\mathrm{ppb} / \mathrm{day}$ in all but the most highly contaminated area during injection. However, air injection 
was most effective at the four corners of the basin, while transfer of oxygen or a helium tracer to piezometers located in the central area was severely limited. This led to lower degradation rates in the unaerated regions and a tendency for chlorinated solvents to be incompletely degraded.

The absence of phosphate in groundwater near the basin suggested that injection of air plus triethylphosphate (TEP) would be of value in enhancing microbial activity. TEP did in fact enhance respiration rates and PCE degradation in the portion of the site containing the highest chlorinated solvent levels. It also led to a decline (compared to air alone) in oxygen levels of soil gas in most areas of the site, suggesting increased microbial metabolic rates. Little or no additional benefit was provided by adding nitrous oxide (as a nitrogen source) or methane (to provide a substrate for methanotrophs which could then carry out a cometabolic degradation of chlorinated solvents). Indeed, microbial respiration rates declined during the latter two injection campaigns. Oxygen was consumed at a mean rate of $0.28 \% \mathrm{O}_{2} / \mathrm{h}$ (corresponding to 4.2 $\mathrm{mg}$ total petroleum hydrocarbons $/ \mathrm{kg}$ soil/day ) during air or air plus TEP injection, but this rate dropped to $0.12 \% \mathrm{O}_{2} / \mathrm{h} \mathrm{h}$ (corresponding to $1.8 \mathrm{mg}$ total petroleum hydrocarbons $/ \mathrm{kg}$ soil/day ) by the end of the study. This suggests that the better part of the microbial community may have been substrate limited.

In conclusion, natural (intrinsic) biodegradation rates at the DOSB are relatively high and this has already accomplished considerable remediation of the site. The injection of air plus TEP is recommended to achieve maximum cleanup rates and groundwater protection, but intrinsic bioremediation may be an acceptable solution if time is not a driver. Based on an estimated chlorinated solvent soil gas content of $211 \mathrm{ppb}$, the observed PCE degradation rate of 1.7 $\mathrm{ppb} /$ day would result in cleanup of these compounds after a minimum of 124 days (approximately 4 months) of air/TEP injection. Achieving maximal rates would, however, depend on adequate aeration of the soil. It is suggested that additional injection wells be installed in areas exhibiting poor air transfer. Recommended air flow rate is approximately 100 $\mathrm{scfm}$, in order to achieve a minimum average radius of influence of 15 feet for each of the two 380 -foot horizontal wells, corresponding to a minimum total affected soil volume of $5.4 \times 10^{5}$ $\mathrm{ft}^{3}$. TEP should be added at concentrations of not more than $0.007 \%(\mathrm{v} / \mathrm{v})$ and should be discontinued when no further stimulatory effect is observed. The injection of methane $(4 \% \mathrm{v} / \mathrm{v}$ in air) will be required if $\mathrm{PCE}, \mathrm{TCE}$, and PAH's persist after a reasonable period of bioventing. 


\section{Background}

The D-area Oil Seepage Basin (DOSB) is defined as the waste unit located between unimproved dirt Roads A-4.4 and A-4.5, approximately $1.6 \mathrm{~km}$ ( 1 mile) north of the coal-fired D-Area Powerhouse and approximately $3 \mathrm{~km}$ (1.9 mile) from the nearest SRS boundary (Fig. 1). It was originally constructed in 1952 as a series of unlined trenches to dispose of waste oils and other fluids not suitable for burning in powerhouse boilers.

The basin received waste oil products from D Area and other areas on-site that were unacceptable for incineration in the powerhouse boilers. These products included seal oil from the Heavy Water Facility, machine cutting oil, and transformer and other shop fluids. The waste oils and fluids were collected in 208-liter (55-gallon) drums, transported to the basin, opened and dumped into the trenches. These materials were periodically burned along with general office and cafeteria waste. This practice continued until 1973 when open burning ceased at SRS. The DOSB continued to receive waste oils and evidently some chlorinated solvents until 1975 when the basin was removed from service and backfilled with soil.

Under the requirements of CERCLA and the FFA, the DOSB is slated for additional assessment and perhaps, environmental remediation. An interim action was conducted to facilitate final remedy selection. As part of the interim remedial action, all drums, large debris, and principal threat source material were removed during April, May, and June of 1996. During these activities, soils down to eight (sometimes twelve) feet below grade were excavated and sieved to remove debris. Excavated soils were exposed to the atmosphere for a period of time, then raked or pushed back into the previously excavated quadrants. Obviously contaminated soils were mainly placed in the northwestern corner of the excavation.

One method proposed for the cleanup of the DOSB was in situ bioremediation (bioventing), involving the introduction of air and gaseous nutrients to stimulate contaminant degradation by naturally occurring microorganisms. To test the feasibility of this approach, a bioventing system was installed at the site for use in optimization testing by the Environmental Biotechnology Section of the Savannah River Technology Center. During the interim action, two horizontal wells for a bioventing remediation system were installed eight feet below average basin grade. Nine piezometers were also installed. In September of 1996, a generator, regenerative blower, gas cylinder station, and associated piping and nutrient injection equipment were installed at the site and testing was begun. This report describes results of the of the optimization test, together with conclusions and recommendations for the further remediation of the site. 
Figure 1. Location of D Area in relation to Savannah River Site

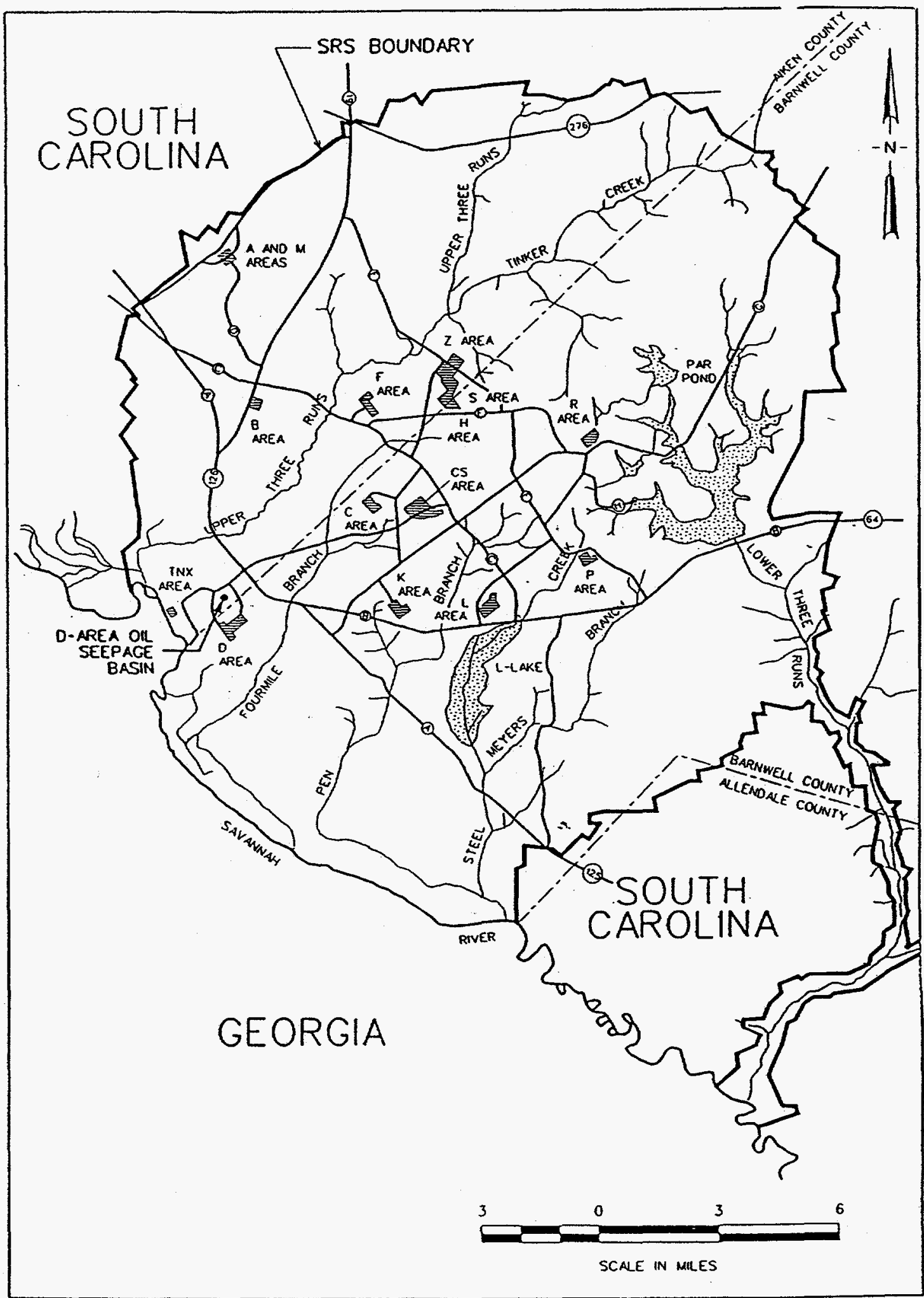




\section{Hydrogeology, Contaminants, and Plume Extent}

The DOSB is in a low lying wetlands area of SRS. Water table depth varies from 4 to 14 feet (usually about 8 feet). The nearest surface water feature is a Carolina bay, a natural wetland located approximately $61 \mathrm{~m}(200 \mathrm{ft})$ west of the unit. Other wetlands exist approximately $137 \mathrm{~m}$ $(450 \mathrm{ft}$ ) to the south of the unit. Groundwater flows in a southerly direction towards a stream and the Savannah River at an average linear velocity of $0.07 \mathrm{ft} /$ day. A potentiometric map of the water table is shown in Fig. 2. The lithology of the DOSB is variable with numerous interbedded sands and clays. A dominant clay lens seems to occur at a depth of $8-12$ foot over most of the site.

Results of extensive monitoring in the DOSB indicate the presence of various metals, volatile organic compounds, and semi-volatile organic compounds in soil and groundwater (see WSRC, 1994). Organic compounds included trichloroethylene (TCE), tetrachloroethylene (PCE), vinyl chloride, 2-methylnaphthalene, acetone, methylene chloride, 4-methyl-2-pentanone, alkyl benzenes, polynuclear aromatic hydrocarbons (PAHs), phthalate, pesticides, polychlorinated biphenyls (PCBs), and the congeners di-benzo-p-dioxin and di-benzo-p-furan. Also identified were fractions of oil and oil compounds including benzene, toluene, ethylbenzene, xylene, and naphthalene.

TCE and vinyl chloride groundwater plumes were partially characterized during 1995, using CPT and groundwater monitoring wells. Both plumes extend in a southerly direction from the unit and their leading edges are not yet completely characterized.

\section{Test Plan Rationale and Objectives}

The D-area Oil Seepage Basin was used for disposal of petroleum-based products and apparently at least some solvents (TCE/PCE). Previous characterization has shown that much of the TCE/PCE has already been converted to vinyl chloride by anaerobic bacteria present in the soil. These findings suggest an environment that is oxygen limited and is already actively degrading the petroleum contaminants present. The introduction of air could potentially increase the biodegradation rate of the remaining petroleum components and stimulate the co-metabolic biodegradation of the remaining chlorinated solvents. Studies at the SRS Sanitary Landfill have shown that biostimulation of the soil microbiota in high carbon environments via air injection alone can stimulate the bacteria to biodegrade all BTEX and chlorinated solvents in the groundwater and soil to below detection limits $(<2 \mathrm{ppb})$. At the SRS Integrated Demonstration Site, gaseous nutrient injection (methane, nitrous oxide, and TEP) in conjunction with air 
D-Area Oil Seepage Basin

In Situ Bioremediation Optimization Test

Final Report
WSRC-MS-96-0797, Rev. 0

Jan. 24, 1997

Figure 2. Potentiometric map of the water table, D Area Oil Seepage Basin
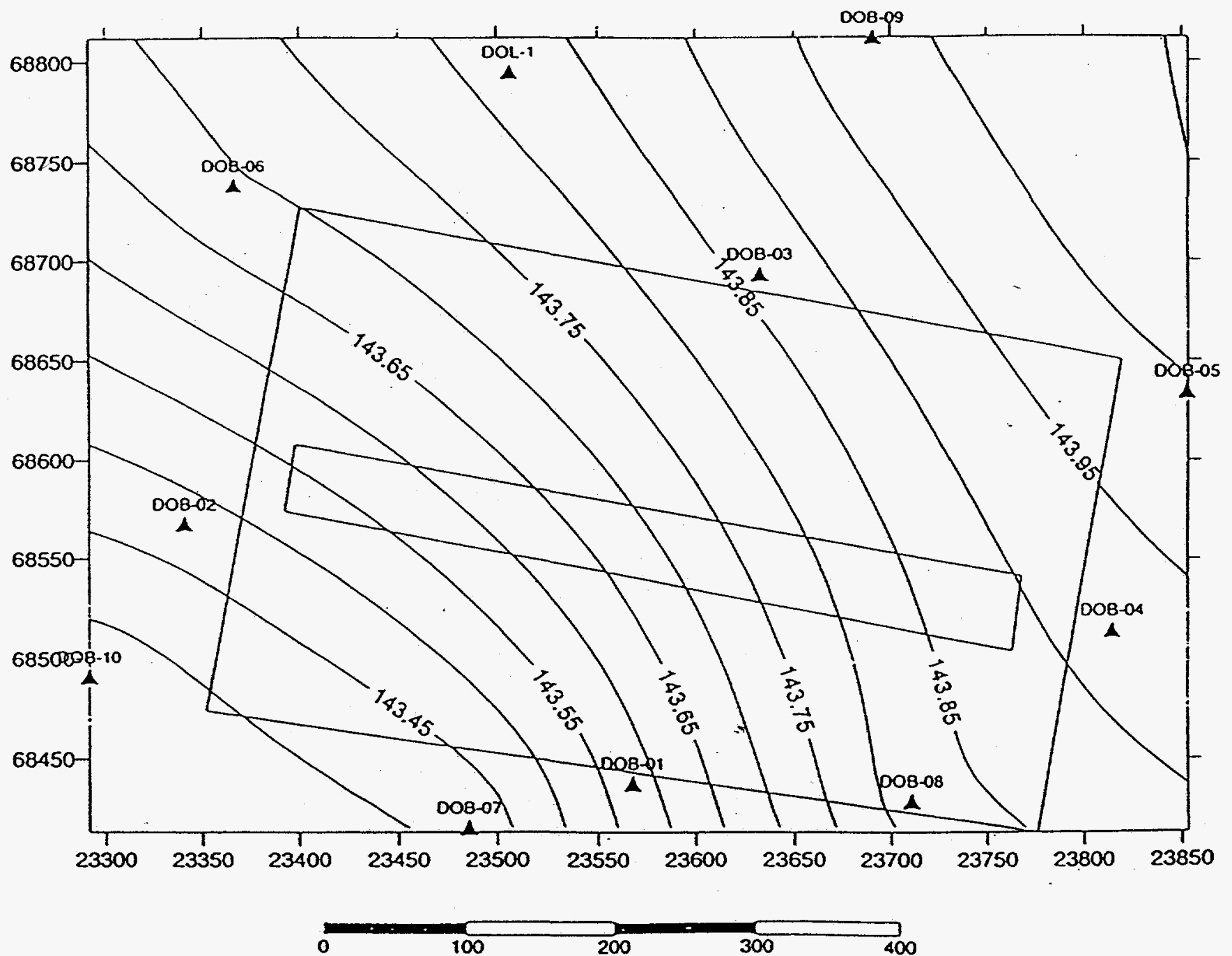
injection has been demonstrated to enhance TCE biodegradation (WSRC, 1993; Hazen et al., 1994). Thus, the focus of this test was to determine the intrinsic rate of bioremediation at the site and the ability of air injection to enhance the in situ biodegradation rate of the contaminants of concern. The effect of injecting nutrients in gaseous form was compared with that of air alone. Data gathered from this test will be used in determining a final disposition/remediation strategy for the site.

The objectives of the D-area Oil Seepage Basin test were as follows:

1. Determine the intrinsic rate of biodegradation of organics in the soil and groundwater.

2. Determine the biodegradation rates of contaminants of concern in the soil and groundwater during biostimulation from air and gaseous nutrient injection.

3. Establish the feasibility of in situ bioremediation of groundwater and soil at the site.

4. Provide data necessary for the functional design criteria for the final remediation system.

\section{Experimental Plan}

The study was being carried out in three phases as follows:

Phase I. Baseline Data Collection. Soil gas and groundwater were monitored over an approximately 3-month period (until regulatory approval was obtained for air injection) to assess baseline parameters for the site.

Phase II. In Situ Respiration and Conservative Tracer Determinations. Air and helium (maximum level 1\% in air) were injected until steady state was reached and then turned off and monitored until pre-injection conditions resumed. Helium injection was also used to evaluate the uniformity of air transfer to the soil.

Phase III. In Situ Biostimulation Using Air and Gaseous Nutrients. Four injection campaigns were carried out. These were: 1) air injection, 2) air plus triethylphosphate (TEP) injection, 3) air plus nitrous oxide injection, and 4) air plus methane $\left(\mathrm{CH}_{4}\right)$ injection. Each 
campaign involved a 1-week injection period, after which soil gas content, water quality, and respiration rates were determined to assess the effects of biostimulation.

Data from these tests has been used to estimate the biodegradation rates of contaminants of concern in the soil and groundwater, evaluate of the feasibility of in situ bioremediation of soil and groundwater at the site, and establish functional design criteria for the final remediation system. 


\section{Methods}

\section{Bioventing System}

A schematic of the bioventing system is shown in Fig. 3. A Sweetwater S-45 regenerative blower was used to inject air at a maximum rate of approximately $90-100 \mathrm{scfm}$ and a pressure of $30-35 " \mathrm{H}_{2} \mathrm{O}$. This flow rate is calculated to result in a minimum average 15 -foor radius of influence for each well and a minimum total affected soil volume of $5.4 \times 10^{5} \mathrm{ft}^{3}$. Flow rates to the two 380-foot horizontal wells were individually measured and controlled. During the TEP injection campaign, triethylphosphate was added by continuously sparging a flow-regulated portion of the air through a tank of liquid TEP and then allowing the TEP-saturated air to enter the horizontal wells. Final TEP concentration was $0.00175-0.0028 \%$ (nom.). In a subsequent campaign, nitrous oxide was added to the air stream at the $0.1 \%$ level from compressed gas cylinders. Air injection was continuous, with nitrous oxide being added for $8 \mathrm{~h} /$ day for 1 week. Methane injection (4\%) was carried out similarly, but was routinely performed for approximately $4 \mathrm{~h}$ /day (in order to avoid the establishment of anaerobic conditions). Helium (1\%) was sometimes added from compressed gas tanks as a tracer in in situ respirometry tests and for use in establishing gas flow patterns at the site. Operation of the system was carried out in accordance with EPA-recommended practices (EPA, 1995). Projected air emissions of volatile, semivolatile, and Standard 8 contaminants were calculated to be insignificant.

\section{Sampling Locations}

Soil gas sampling and pressure measurements were carried out via nine vadose zone piezometers, designated DOB-BV1 through DOB-BV9. These are shown in Figs. 4 and 5. Piezometers extended to a depth of about 5 feet and were screened for the last 2 feet. Details of piezometer construction are shown in Fig. 6. Bundle tubes terminating at 50-foot intervals within the horizontal wells DOB-1HW and DOB-2HW were also occasionally used for gas monitoring (Fig. 4 inset), but these measurements were discontinued during the study because of the risk to sampling equipment posed by the frequent presence of water in the horizontal wells.

Groundwater was sampled via a series of groundwater monitoring wells (DOB 2, 3, 4, 5, 11, 13, 14) located around the periphery of the site. They were selected to include upgradient (DOB 3 , 5), side gradient (DOB 2,4) and downgradient (DOB 11, 13, 14) sampling points. Approximate locations of these and other nearby monitoring wells are shown in Fig. 4. Table 1 shows the total depths and screened areas of these wells. 
D-Area Oil Seepage Basin

In Situ Bioremediation Optimization Test

Final Report

Figure 3. Schematic drawing of bioventing system
WSRC-MS-96-0797, Rev. 0

Jan. 24, 1997

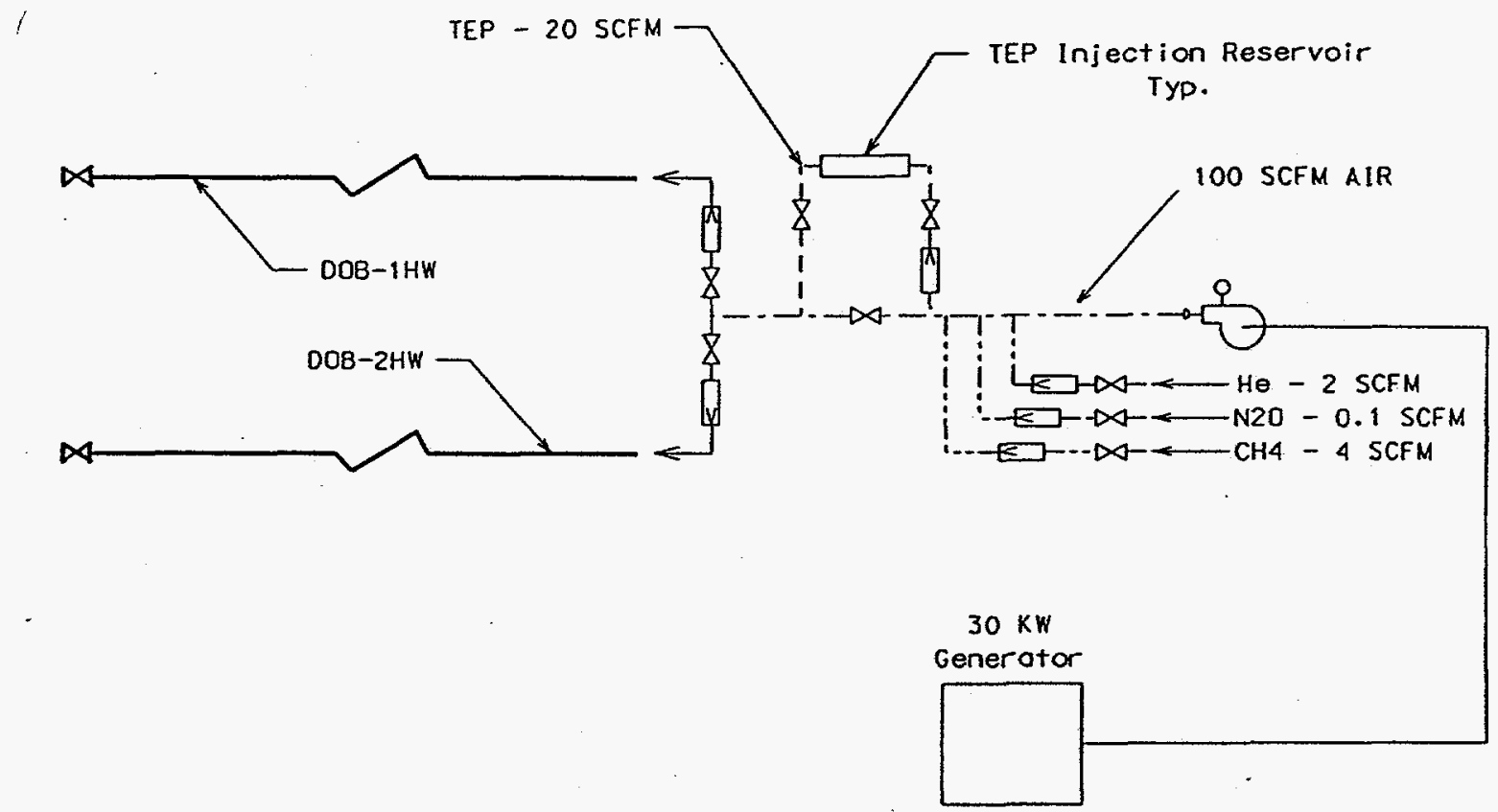


D-Area Oil Seepage Basin

In Situ Bioremediation Optimization Test

Final Report
WSRC-MS-96-0797, Rev. 0

Jan. 24, 1997

Figure 4. As-built drawing showing horizontal wells and piezometers

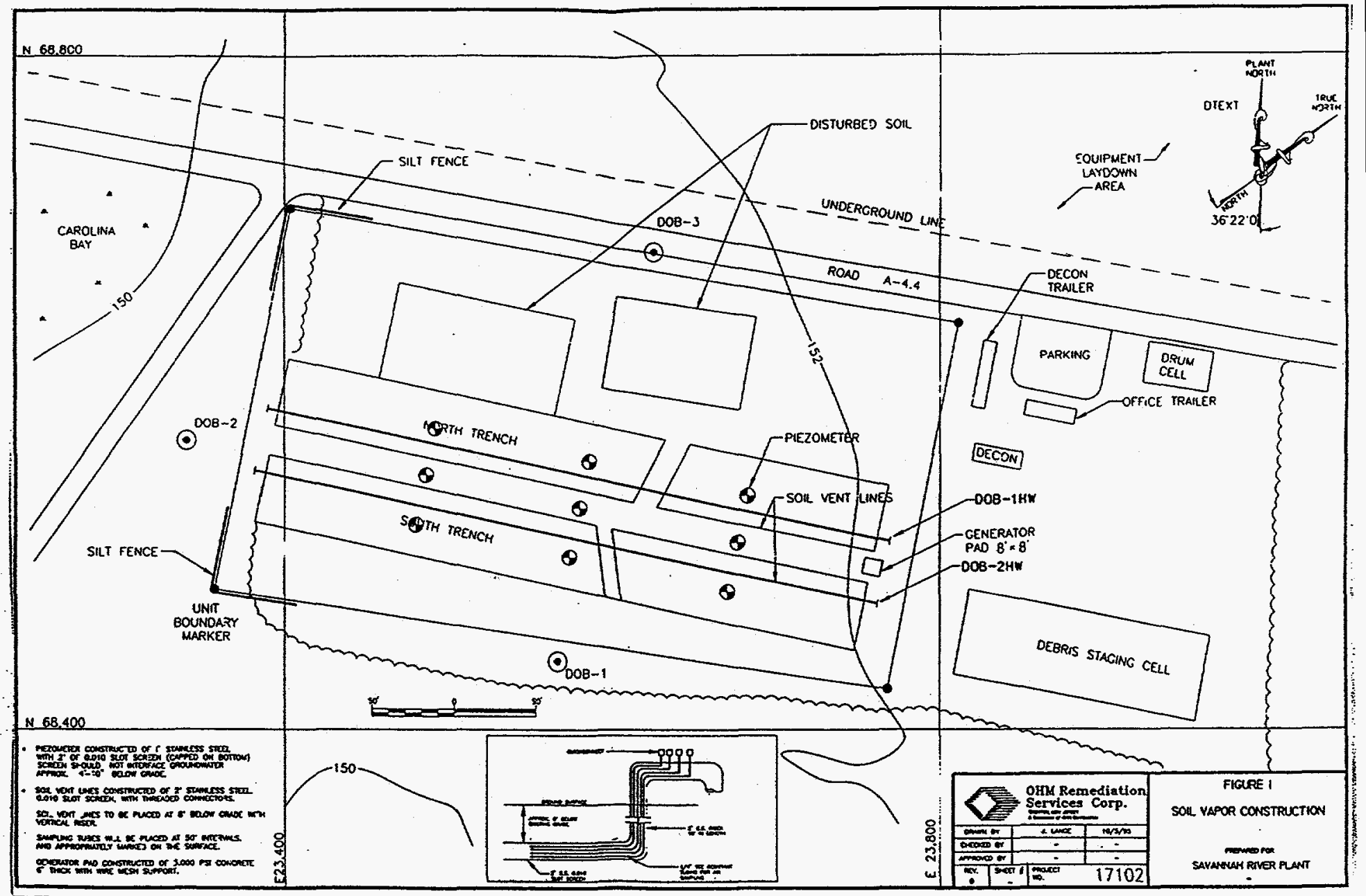


Final Report

Figure 5. Locations of monitoring wells and piezometers
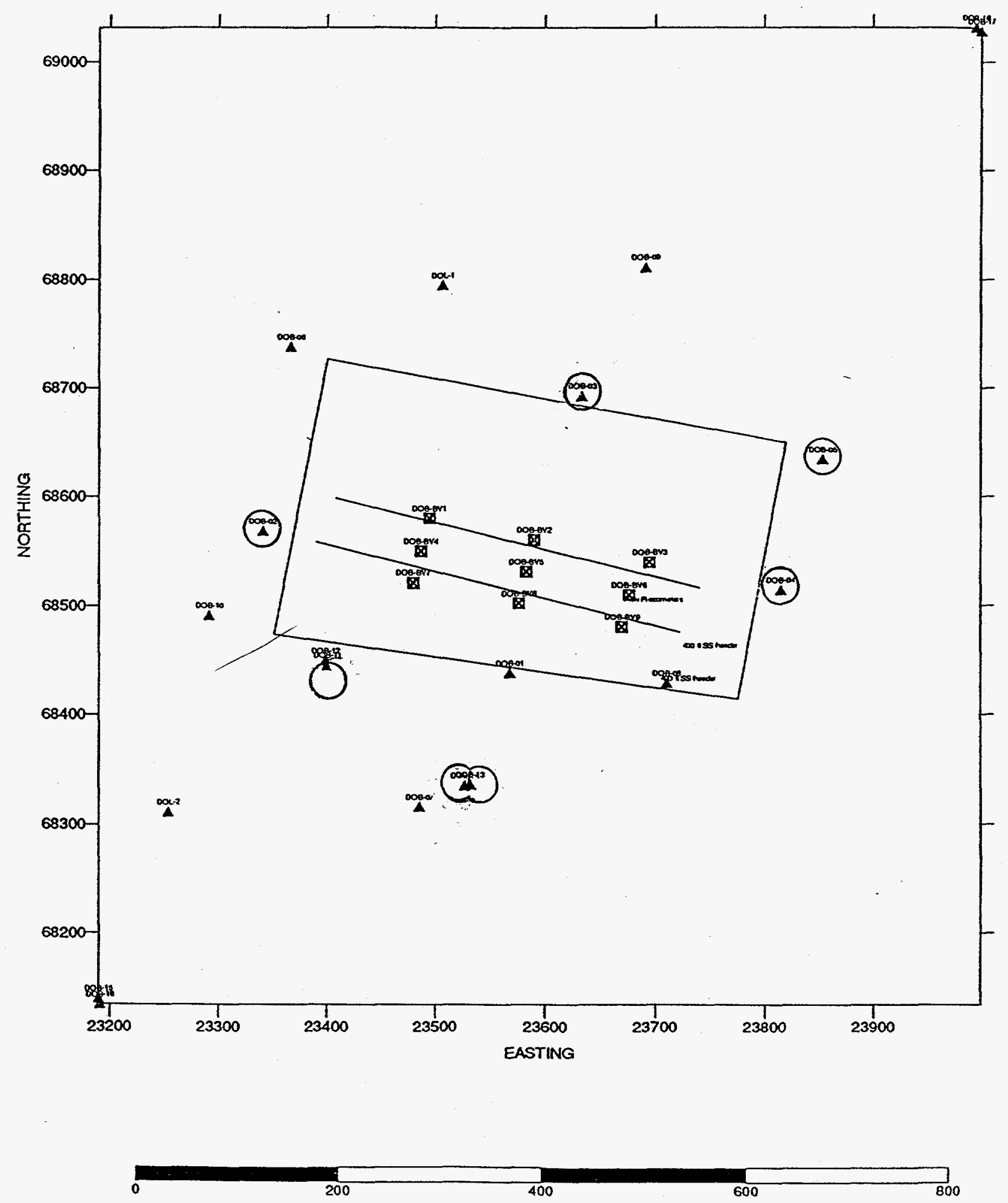
D-Area Oil Seepage Basin

In Situ Bioremediation Optimization Test

WSRC-MS-96-0797, Rev. 0

Final Report

Jan. 24, 1997

Figure 6. Details of piezometer construction

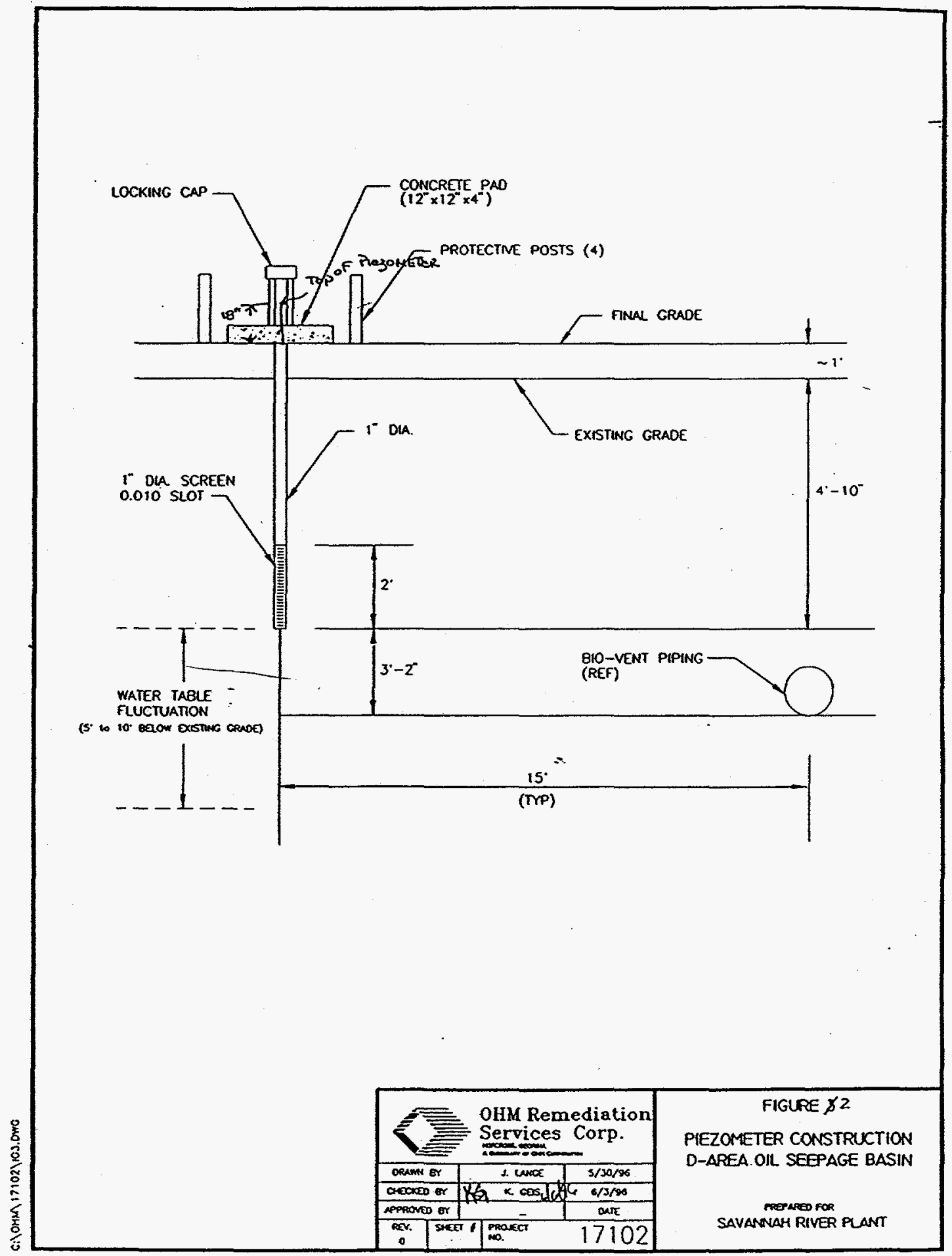


D-Area Oil Seepage Basin

In Situ Bioremediation Optimization Test

Final Report

Table 1. Screen zones of monitoring wells.

\begin{tabular}{|l|c|c|}
\hline Well & Top of Screen (ft) & Bottom of Screen (ft) \\
\hline DOB-2 & 5 & 35 \\
\hline DOB-3 & 5 & 35 \\
\hline DOB-4 & 12 & 42 \\
\hline DOB-5 & 3 & 23 \\
\hline DOB-11 & 18.7 & 23.7 \\
\hline DOB-13 & 18.5 & 23.5 \\
\hline DOB-14 & 11.7 & 16.7 \\
\hline
\end{tabular}




\section{Experimental Procedures}

Monitoring of soil gas and groundwater was performed during the July 18 - September 26, 1996 period to establish baseline parameters for the site prior to the start of bioventing. After baseline measurements of soil gas and groundwater (Phase I) had been completed, air injection (45 $\mathrm{scfm}$ /horizontal well) was commenced on September 30,1996 in preparation for in situ respiration and conservative tracer testing (Phase II). The increase in oxygen levels was measured at all piezometers during the injection, and air flow was stopped when oxygen concentrations appeared maximal (after 3 days' continuous injection). The subsequent decrease in oxygen levels was then monitored over a 44-h period in order to establish oxygen consumption rates for the site. These rates were then used to calculate estimated rates of petroleum hydrocarbon oxidation.

After the initial respirometric test had been concluded, air injection recommenced on October 5 , 1996) in an attempt to stimulate microbial biodegradation by prolonged enhancement of oxygen levels in the soil gas (Phase III). During this time, a helium tracer test (Phase II) was carried out. The inert gas was added to the air stream (at about the 1\% level) for 4 hours and the rise in helium concentrations at the piezometers was measured. Helium concentrations in the injected air were monitored by periodically opening the valve at the end of horizontal well DOB-2HW to allow insertion of a helium probe into the air stream.

Continuous air injection was carried out for 5 days (in addition to the 3 days of injection prior to respirometric measurements). At the conclusion of this injection campaign, all gas and water monitoring and analyses were repeated for comparison with baseline values. Gas samples were collected both while air was being injected and after the system had been turned off for several days.

During the final 4 hours of air injection (October 10,1996), 1\% (nominal) helium was again added to the air stream as a tracer. Air and helium injection was then discontinued, and a second respirometric test was performed to determine if any enhancement of hydrocarbon degradative potential had occurred. This test was performed in the same manner as the previous one, except that helium as well as oxygen concentrations were measured at each time point to assess the influence of surface air diffusion on soil gas content.

The TEP/air injection campaign was carried out during the October $22-31$ period. Injection was interrupted twice during this time due to generator outages, and total injection time is estimated at 6.5 - 7 days. Nitrous oxide/air injection was performed from November 8, 1996 to 
November 15, 1996 ( 7 days of air injection), with the total nitrous oxide injection time being 52 $\mathrm{h}$ ( 5 - $8 \mathrm{~h} /$ day). Methane injection was carried out from November 21,1996 to November 27, 1996 (6.2 days air injection), with total methane injection time being $29 \mathrm{~h}$ (averaging 4.1 $\mathrm{h}$ /day). For safety reasons, methane levels in the injected air were monitored at $2-\mathrm{h}$ intervals and flow was adjusted so than methane levels did not exceed 4\% (LEL $=5 \%)$. Methane levels in the cylinder shed (floor level) were similarly monitored as a precaution against leakage. Each campaign was immediately followed by a respirometric test, conducted as described above. $1 \%$ (max.) helium was added to the air stream for use as a tracer for several hours prior to each test. On the final day of each campaign, all groundwater monitoring wells and piezometers were monitored and sampled. A second set of soil gas samples were taken in each case after the injection system had been turned off for several days.

A second, longer term tracer study of air transfer patterns at the site was performed during the November 12 - 15 period (simultaneously with nitrous oxide injection). In this test, $\mathrm{He}(1 \%)$ was added to the air stream for approximately $8 \mathrm{~h} /$ day on three consecutive days. He levels were measured on a daily basis at each piezometer and at the far end of horizontal well DOB-HW2.

Emission of volatile organics from the soil surface at the site was measured on December 4, 1996. These measurements were performed both during air injection $(1 \mathrm{~h})$ and with the injection system turned off.

\section{Analytical Methods}

Soil Gas Measurements. A Landtec GEM-500 gas extraction monitor was used in the field to measure $\mathrm{CH}_{4}, \mathrm{CO}_{2}$, and $\mathrm{O}_{2}$ in soil gas from the vadose zone piezometers. Pressure in the piezometers was also measured using this instrument. Helium levels were measured by means of a Mark Products Model 1820A helium detector. A vacuum pump was used to provide a stream of soil gas for monitoring; prior to recording measurements the piezometers were purged for 2 min or until stable readings were obtained. Soil gas samples were collected in Tedlar gas sampling bags (Supelco, Inc.), placed in a cooler, and transported to the laboratory to be analyzed within $24 \mathrm{~h}$ for VOC (volatile organic compounds). VOC content of the samples was analyzed using a Hewlett-Packard 5890 gas chromatograph equipped with a $75 \mathrm{~nm}$ diameter Vocol column, operated with splitless or 1:1 split injection, a $5 \mathrm{ml} / \mathrm{min}$ flow rate, and a 50 $\mathrm{ml} / \mathrm{min}$ purge rate, and either an electron capture detector or an electron capture detector plus a flame ionization detector; or a Hewlett Packard 5890 Series II gas chromatograph equipped with an electron capture detector and a $60 \mathrm{~m}, 0.32 \mathrm{~nm}$ diameter Vocol column, operated with splitless injection, a $0.870 \mathrm{ml} / \mathrm{min}$ flow rate, and a $50 \mathrm{ml} / \mathrm{min}$ purge rate. 
Emission of volatile organics from the soil was measured using a flux chamber and an infra-red analyzer (Bruel \& Kjaer type 1302 infra-red photoacoustic multi-gas monitor).

Groundwater Measurements. Groundwater characteristics were measured during baseline assessment and at the end of each injection campaign. A HydroLab Scout 2/Datasonde 3 multiparameter water quality data logger equipped with a flow-through cell was used to analyze water on site for dissolved oxygen, redox potential, conductivity, $\mathrm{pH}$, and temperature. Water samples were then collected, placed in a cooler, and transported to the laboratory for analysis. BTEX, vinyl chloride, dichloroethylene, trichloroethylene, tetrachloroethylene, total petroleum hydrocarbons, and PAH levels were determined using a Hewlett-Packard GC-MS system, consisting of a Model 5890 Series II gas chromatograph equipped with a Series 5972 mass selective detector and a model 7694 headspace sampler. Total petroleum hydrocarbons and PAH were determined following a chloroform extraction. A HP- 5 column $(50 \mathrm{~m}$ length, $0.32 \mathrm{~nm}$ diameter) was used. Chloride, nitrate, nitrite, phosphate, and sulfate were quantified using a Dionex Model QIC2 ion chromatograph equipped with an IonPac Fast Anion column. An isocratic elution and a $2.0 \mathrm{ml} / \mathrm{min}$ flow rate were used. Microbial analyses (direct enumerations and colony counts) were also carried out on groundwater samples. Total bacterial counts were performed by the Acridine Orange Direct Count (AODC) Method. Appropriate aliquots of sample were stained with acridine orange for $2 \mathrm{~min}$ on a $0.2 \mu \mathrm{m}$ Nuclepore filter in a vacuum manifold, then filtered. The filter was then mounted on a slide on top of a drop of immersion oil. One drop of immersion oil was added on top of the filter and a cover slip applied. Cells were then counted using epifluorescence microscopy and total cell numbers were calculated. Culturable heterotrophic bacteria and petroleum hydrocarbon degraders were enumerated by colony counts. A tenfold dilution series (using phosphate buffered saline) was constructed for each sample. A $0.1 \mathrm{ml}$ aliquot of each dilution was then evenly spread over duplicate plates containing appropriate agar-solidified media. The 1\% Peptone-Trypticase-Yeast ExtractGlucose (PTYG) medium of Balkwill (1989) was used to enumerate total culturable aerobic and facultatively anaerobic heterotrophic bacteria. Cyclohexamide was added to the medium to prevent fungal overgrowth. A mineral salts medium (MPN Medium) containing no dissolved carbon source was used to enumerate petroleum hydrocarbon degraders. Inoculated MPN plates were incubated in a desiccator containing a small amount of diesel fuel; the diesel fumes thus provided the sole carbon source (other than the agar itself and carbon sources present in the inoculum). The impact of the latter carbon sources on estimates of petroleum hydrocarbon degrader numbers was assessed by inoculating MPN control plates which were then incubated in the absence of diesel fumes. All plates were incubated 1 week before colonies were counted and bacterial densities calculated. 


\section{Results}

\section{Soil Gas Measurements}

Effectiveness of air transfer. During baseline measurements (before air injection), soil gas contained low oxygen levels and elevated carbon dioxide levels (Fig. 7). Continuous air injection into both horizontal wells ( 45 - $50 \mathrm{scfm} /$ well) was initiated on September 30, 1996. This caused oxygen to increase to near-atmospheric levels and carbon dioxide levels to decline in soil gas measured at piezometers DOB-BV1, 3, 7, and 9 (see Figs. 4 and 5 for piezometer locations). Positive pressures were also measured at these piezometers. Piezometers DOB-BV2, 5 , and 8 , however, invariably showed pressure readings at or near zero and did not attain oxygen levels as high as at the corner locations, while DOB-BV4 and DOB-BV6 showed mixed or intermediate results. These data suggested that air flow may not have been as rapid in the central portion of the previously excavated area as near the corners.

To test this idea, we conducted a 4-hour helium tracer test (Fig. 8). Helium was injected at a concentration of approximately $0.9 \%$ in air (measured at the far end of horizontal well DOB$2 \mathrm{HW}$, which was opened periodically to permit gas level monitoring). Fig. 8 shows data from two piezometers at well-aerated corner locations (DOB-BV3 and DOB-BV9) as well as from a piezometer showing little elevation in oxygen levels (DOB-BV6). It can be seen that $\mathrm{He}$ penetrated rapidly to DOB-BV9 and somewhat more slowly to DOB-BV3, but did not reach DOB-BV6 at all during the duration of the test. Helium reached DOB-BV1 and DOB-BV7, but little effect was seen at DOB-BV2, 4, 5, and 8 (data not shown). These findings further indicate that gas flow through the soil is restricted in the central portions of the contaminated area.

A tracer test of longer duration was conducted in order to elucidate the extent of air flow to the central portions of the DOSB (Table 2). Helium ( $0.9 \%$, measured at the west end of DOB-HW2) was injected for approximately $8 \mathrm{~h} /$ day for 3 days. Table 2 shows that helium levels at piezometers DOB-BV1, 3, 7, and 9 (the corner locations) increased to near their maximal levels within about $6.5 \mathrm{~h}$ after He injection commenced. Helium concentrations increased steadily but much more slowly at DOB-BV 6 and 8 . They remained below $20 \%$ of the input concentration after 3 days' injection. Piezometers DOB-BV 2, 4, and 5 never exceeded $7 \%$ of 
D-Area Oil Seepage Basin

In Situ Bioremediation Optimization Test

WSRC-MS-96-0797, Rev. 0

Final Report

Jan. 24, 1997

Figure 7. Soil gas levels at the DOSB during baseline measurements (before air injection).

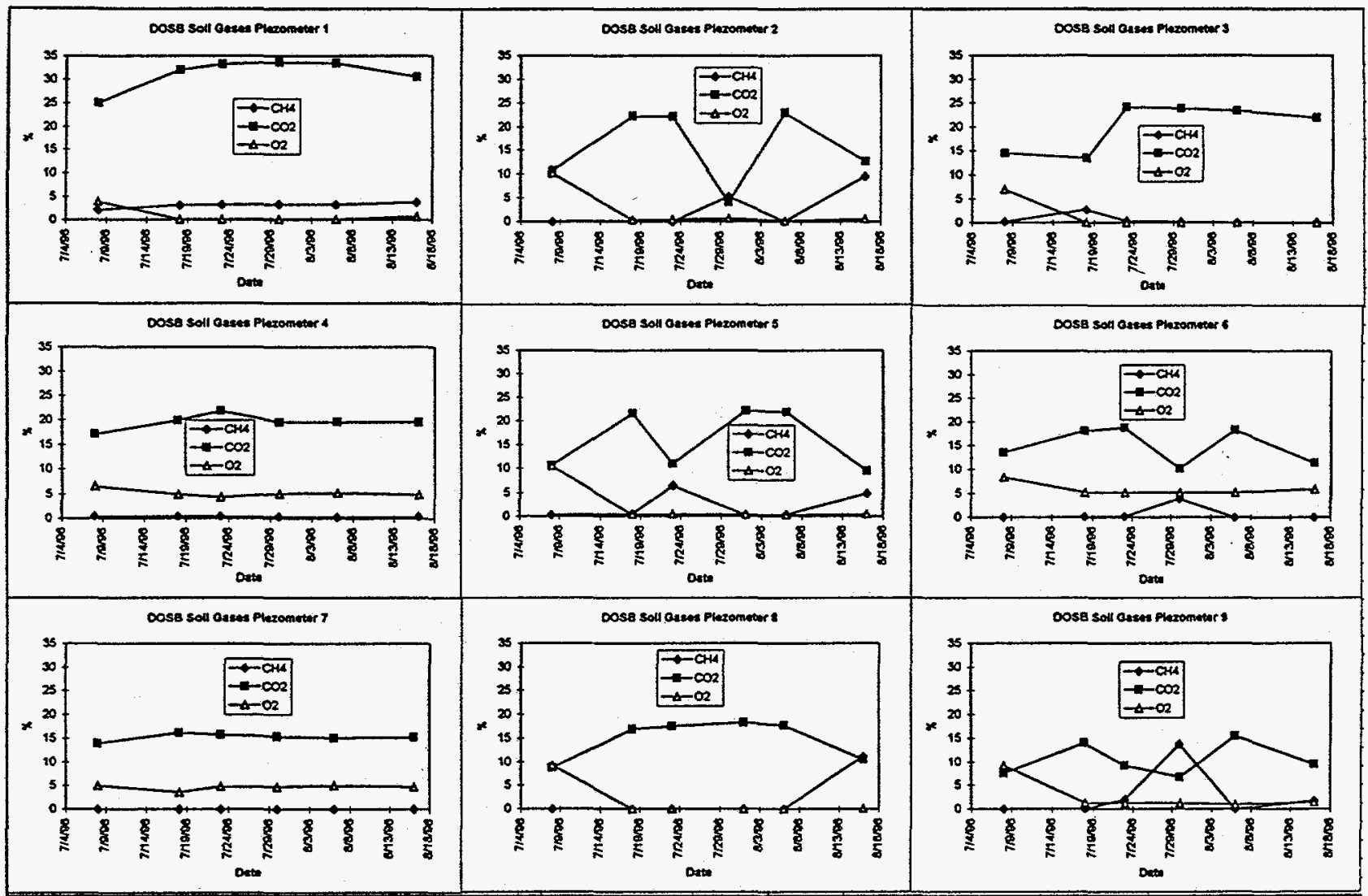


Figure 8. Sample data from helium tracer test

\section{Helium Tracer Test}

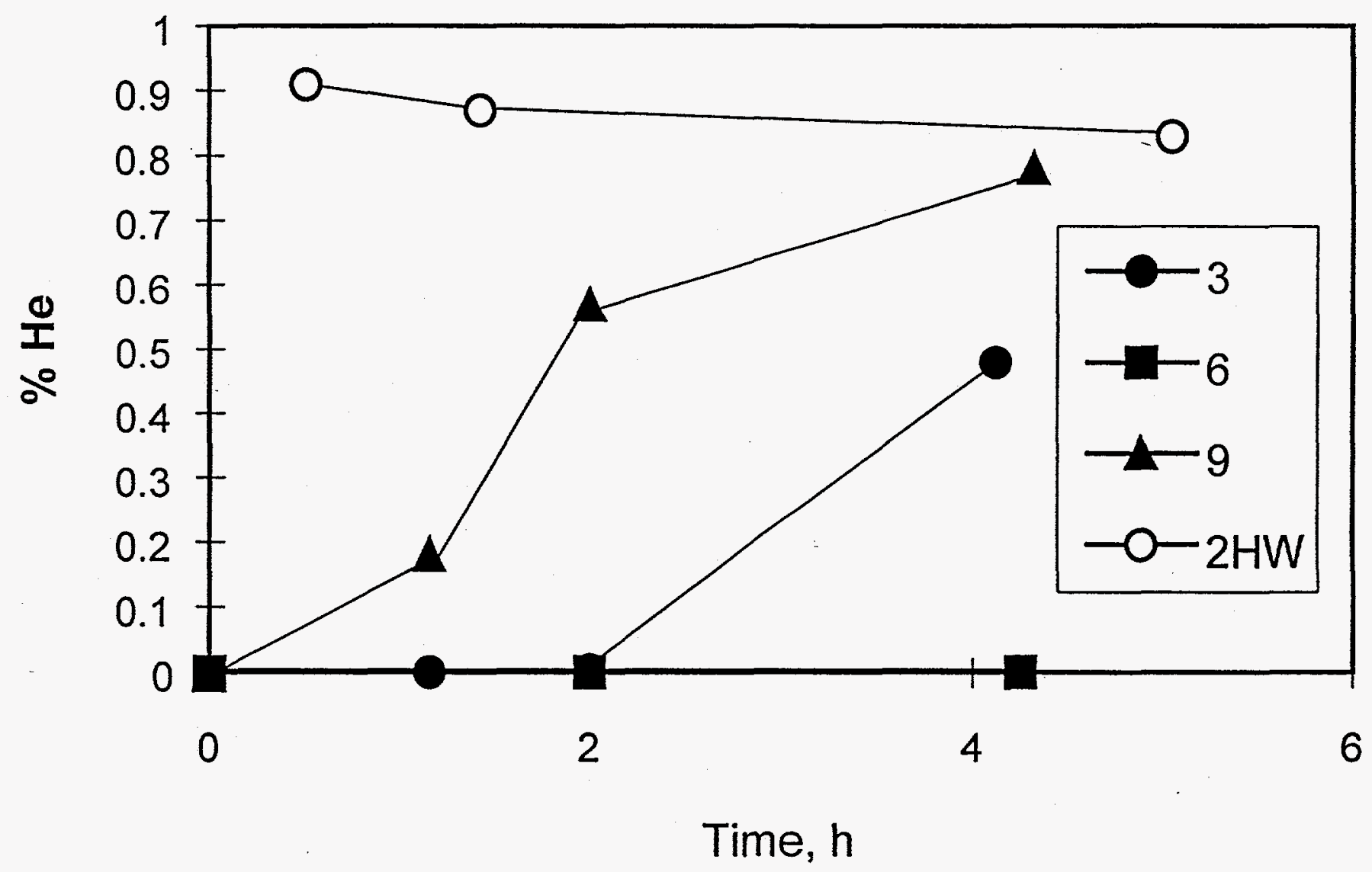


Final Report

Table 2. Three-day helium tracer test.

\begin{tabular}{|l|l|l|l|l|l|l|l|l|l|l|}
\hline Date & Time & $\begin{array}{l}\text { DOB- } \\
\text { BV1 }\end{array}$ & $\begin{array}{l}\text { DOB- } \\
\text { BV2 }\end{array}$ & $\begin{array}{l}\text { DOB- } \\
\text { BV3 }\end{array}$ & $\begin{array}{l}\text { DOB- } \\
\text { BV4 }\end{array}$ & $\begin{array}{l}\text { DOB- } \\
\text { BV5 }\end{array}$ & $\begin{array}{l}\text { DOB- } \\
\text { BV6 }\end{array}$ & $\begin{array}{l}\text { DOB- } \\
\text { BV7 }\end{array}$ & $\begin{array}{l}\text { DOB- } \\
\text { BV8 }\end{array}$ & $\begin{array}{l}\text { DOB- } \\
\text { BV9 }\end{array}$ \\
\hline $11 / 12 / 96$ & 0856 & 0 & 0 & 0 & 0 & 0 & 0 & 0 & 0 & 0 \\
\hline $11 / 12 / 96$ & 1520 & 0.8 & 0.01 & 0.78 & 0.01 & 0 & 0.01 & 0.64 & 0.02 & 0.79 \\
\hline $11 / 13 / 96$ & 1335 & 0.83 & 0 & 0.83 & 0.07 & 0.02 & 0.1 & 0.69 & 0.06 & 0.87 \\
\hline $11 / 14 / 96$ & 1655 & 0.73 & 0 & 0.72 & 0 & 0.02 & 0.11 & 0.51 & 0.09 & 0.86 \\
\hline $11 / 15 / 96$ & 1117 & 0.77 & 0 & 0.73 & 0.04 & 0.01 & 0.17 & 0.56 & 0.12 & 0.92 \\
\hline
\end{tabular}


the input concentration and appeared to be undergoing no further increase at the time the test was concluded. Air flow seems severely restricted at these latter locations.

Oxygen and $\mathrm{CO}_{2}$ levels in soil gas. Baseline soil gas data (Fig. 7) indicate that considerable microbial metabolic activity was present in the DOSB prior to air injection. This is evidenced by the low oxygen levels, elevated carbon dioxide levels, and the presence of methane at most piezometers. These data show that microbial activity consumed all ambient soil gas oxygen and created anaerobic conditions necessary for methanogenic bacteria. Since background soil gas and groundwater oxygen are normally present in the SRS subsurface, excessive amounts of biodegradable organic carbon (contaminants) must have been present at the DOSB. The injection of air caused an increase in oxygen content, a decrease in carbon dioxide content, and the disappearance of methane (except at some piezometers during methane injection) in the soil gas (Appendix 1 lists soil gas data for the entire study). However, differences were seen between the various injection campaigns. Although such differences may reflect abiotic as well as microbially mediated processes, they are suggestive of changes in bacterial oxygen consumption and carbon dioxide evolution as a result of the treatments. These observations are summarized in Fig. 9, which shows mean oxygen/carbon dioxide ratios during the four injection campaigns. It can be seen that, at six of the nine piezometers, the lowest oxygen/carbon dioxide ratios occurred during air/TEP injection, while air alone yielded the lowest ratio at two of the remaining locations.

In situ respirometry. Rates of microbial activity were determined using in situ respirometry. Baseline activity was measured following three days of air injection to raise the oxygen concentration of the soil gas to a level which would allow the test to be performed. At this point, air injection was stopped and the subsequent decline in oxygen and increase in $\mathrm{CO}_{2}$ were measured over a 44-hour period. Subsequent tests were performed immediately following each 1-week injection campaign. Helium ( $1 \%$ max.) was injected into the air stream during the final hours of each injection campaign, after which the air and helium supply was turned off and oxygen consumption was monitored. Fig. 10 shows typical experimental data, while results of all tests are shown in Table 3. Only oxygen data are shown, since hydrocarbon degradation rates can be more accurately calculated from $\mathrm{O}_{2}$ consumption rates rather than $\mathrm{CO}_{2}$ evolution rates, which are influenced by $\mathrm{pH}$ and soil type (EPA, 1995). Omitted entries in Table 3 indicate that a piezometer failed to show any consistent trend in oxygen levels and hence that an oxygen consumption rate could not be calculated. Piezometers where this occurred in some or all tests were the same ones (DOB-BV 2, 4, 5,6, and 8) previously shown to exhibit impaired gas transfer during tracer studies. Table 3 shows oxygen consumption at each piezometer $\left(\% \mathrm{O}_{2} / \mathrm{h}\right)$ as well as estimated total petroleum hydrocarbon oxidation rates per $\mathrm{kg}$ soil per day ( $\mathrm{mg}$ 
D-Area Oil Seepage Basin

In Situ Bioremediation Optimization Test

Final Report

Figure 9. Mean oxygen/ $\mathrm{CO}_{2}$ ratios during injection campaigns.

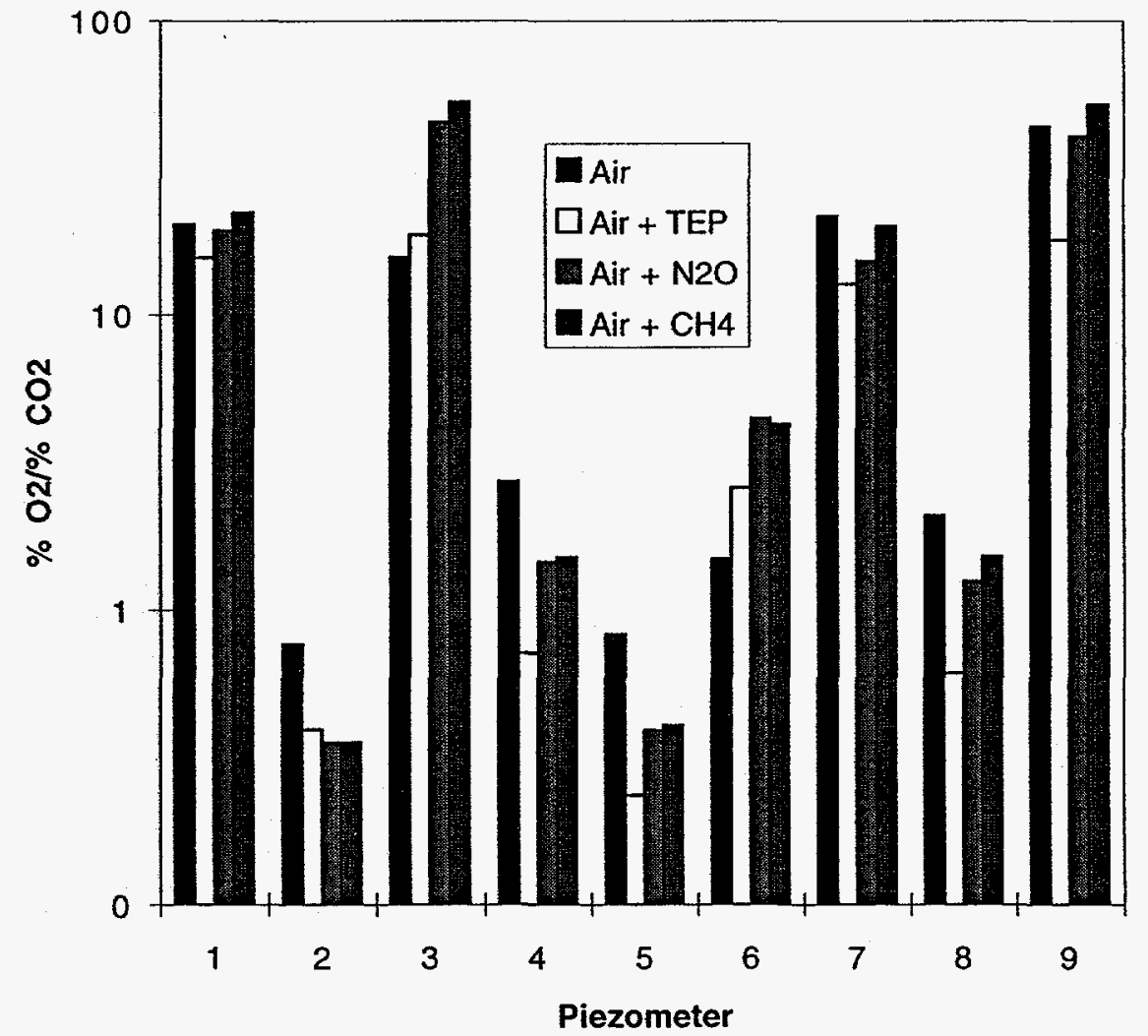

Piezometer
0797, Rev. 0

Jan. 24, 1997 
D-Area Oil Seepage Basin

In Situ Bioremediation Optimization Test

Final Report

Figure 10. Sample data from in situ respirometry test

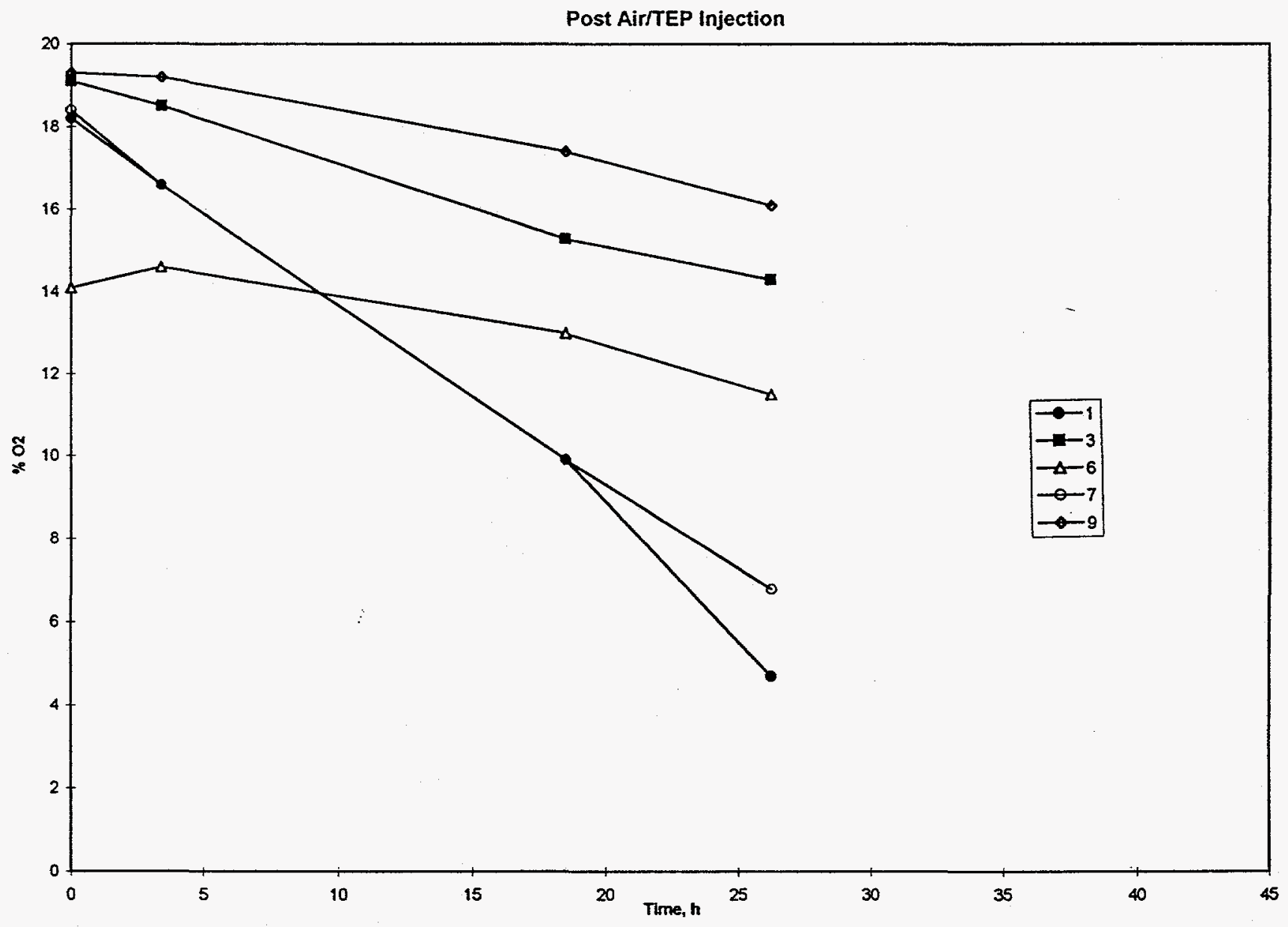


D-Area Oil Seepage Basin

In Situ Bioremediation Optimization Test

Final Report

WSRC-MS-96-0797, Rev. 0

Jan. 24, 1997

Table 3. Summary of in situ respirometry data

Piezometer

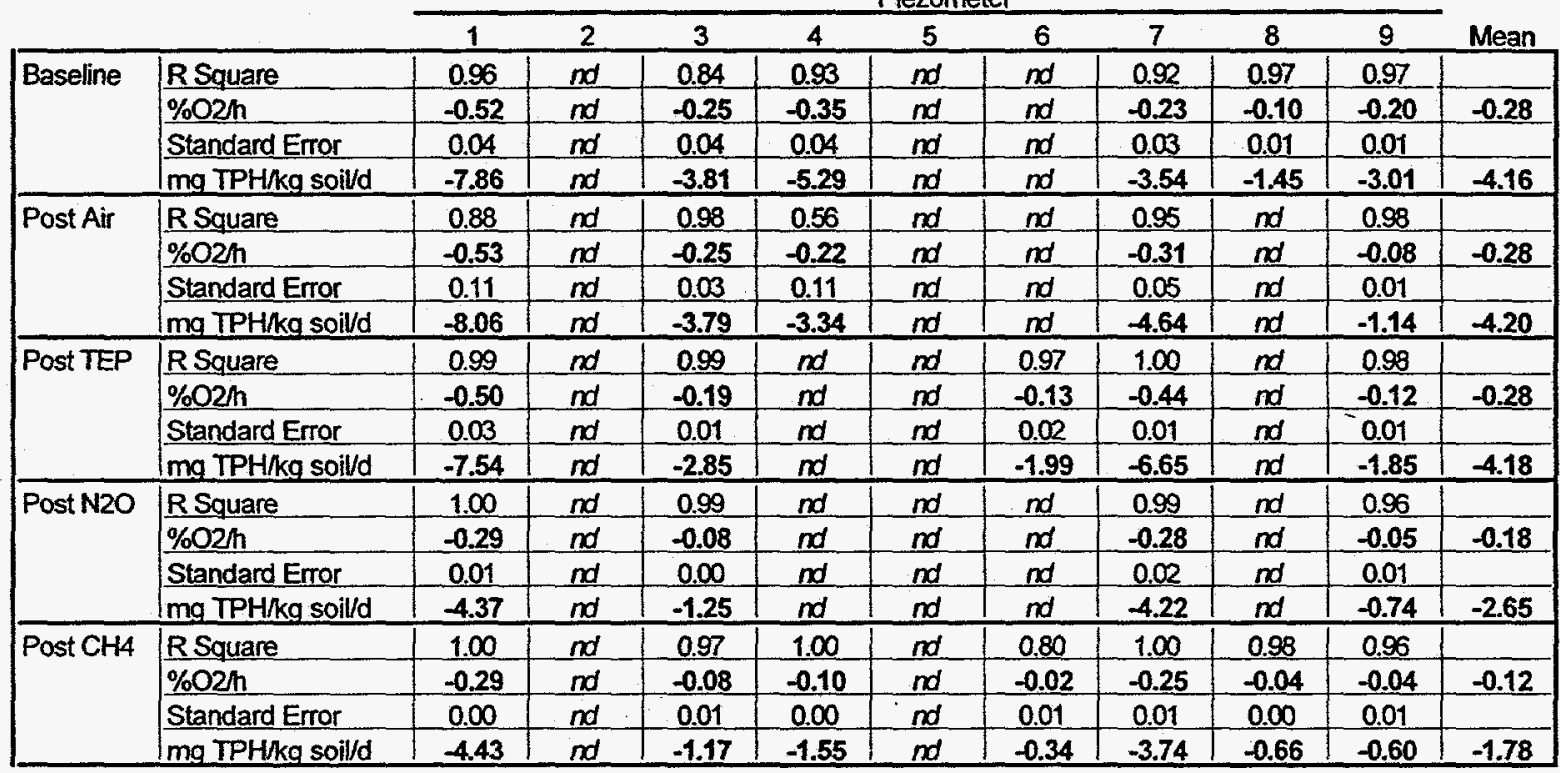

$n d=$ no data

Formula (from EPA Manual): $\quad k b=(k 0)(P V)(d O 2)(C)(0.01) / B D$ soil

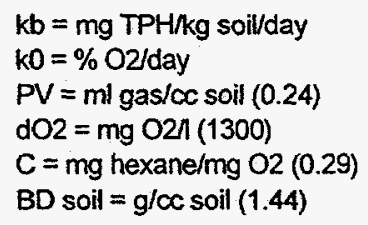


$\mathrm{TPH} / \mathrm{kg} / \mathrm{d}$ ), estimated using the method of EPA (1995). Calculated baseline degradation rates averaged $4.2 \mathrm{mg} \mathrm{TPH} / \mathrm{kg}$ soil/day, a rather high value. It is evident that the potential for high contaminant degradation rates is present at the DOSB, even after relatively brief aeration. Especially high rates of oxygen consumption were observed at DOB-BV1, located in a part of the site reported to have contained the most heavily petroleum-contaminated soils (WSRC, 1994). Furthermore, the rates shown may actually represent an underestimation of the actual degradative potential. Examination of the ratio of oxygen to a helium tracer (Table 4) show a fairly rapid loss of the inert tracer from the soil gas. Thus, there appears to have been considerable exchange with surface air during the period of the test, leading to an underestimation of oxygen consumption. Influence by surface air is not entirely unexpected due to the shallow depth of the piezometers (five feet). Although baseline rates of oxygen consumption were quite high, the average rate underwent little increase as a result of injection of air or air plus TEP, and decreased (on average) during subsequent injections. It is possible that the injection of air for three days prior to the baseline test was sufficient to stimulate the microbial community, and that oxygen consumption during this test may therefore not represent a true baseline. This would explain the similarity between results of the baseline test and that following air injection. Similarity between results of air injection and air plus TEP injection could indicate either that phosphorus enrichment is not required, or that during TEP injection the system was becoming carbon limited due to a decline in contaminant levels. The latter interpretation is supported by the observation (Table 3) that TEP did stimulate respiration at DOB-BV7, located in an area with high VOC content (as shown in Fig. 11 and 12 as well as Appendix 2). Reduced contaminant levels would also explain the decline in oxygen consumption (to levels below those seen with air alone) during nitrous oxide and methane injections.

Volatile organics in gas samples. Changes in levels of tetrachloroethylene and its degradation products trichloroethylene, 1,1 dichloroethylene, and cis-dichloroethylene, as well as carbon tetrachloride, chloroform, and trichloroacetate are shown in Fig. 11 and 12 (PCE and TCE results) and Appendix 2 (all results). It was concluded that early results indicating the presence of substantial amounts (frequently $>1 \mathrm{ppm}$ ) of vinyl chloride actually represented a freon compound and these data are not included in the results. Indeed, analyses of Interim Action and Phase IV soil samples indicate very low levels of vinyl chloride at the DOSB (G. Rucker, personal communication). Although gas samples were taken both before and after turning off the air supply, only data collected with the system turned off are plotted. This provides a better comparison with baseline (pre-injection) data, and eliminates the possibility of artifacts due to differences in air flow to the piezometers during sample collection. 
D-Area Oil Seepage Basin

In Situ Bioremediation Optimization Test

Final Report
WSRC-MS-96-0797, Rev. 0

Jan. 24, 1997

Table 4. Oxygen/helium ratios during in situ respirometry

Piezometer

\begin{tabular}{|c|c|c|c|c|c|c|c|c|c|c|}
\hline Campaign & Time, $h$ & 1 & 2 & 3 & 4 & 5 & 6 & 7 & 8 & 9 \\
\hline \multirow[t]{5}{*}{ Air } & 0.00 & 25 & nd & 39 & 120 & nd & $n d$ & 30 & $n d$ & 25 \\
\hline & 0.05 & 25 & nd & 30 & 194 & nd & nd & 33 & $n d$ & 25 \\
\hline & 4.00 & 26 & nd & 38 & 342 & $n d$ & nd & 38 & nd & 29 \\
\hline & 19.50 & 23 & nd & 39 & 121 & nd & nd & 39 & nd & 30 \\
\hline & 27.00 & 3 & nd & 41 & 62 & $n d$ & nd & 47 & $n d$ & 35 \\
\hline \multirow[t]{4}{*}{ Air/TEP } & 0.00 & 27 & nd & 29 & nd & nd & $n \mathrm{He}$ & 30 & $n d$ & 28 \\
\hline & 3.42 & 23 & nd & 30 & nd & nd & $\mathrm{nHe}$ & 29 & $n d$ & 30 \\
\hline & 18.50 & 17 & nd & 34 & nd & nd & $\mathrm{nHe}$ & 30 & $n d$ & 36 \\
\hline & 26.25 & 8 & nd & 35 & nd & nd & $n \mathrm{He}$ & 22 & nd & 38 \\
\hline \multirow[t]{4}{*}{ Air/N2O } & 0.00 & 25 & nd & 27 & nd & nd & nd & 34 & nd & 22 \\
\hline & 4.25 & 28 & $n d$ & 30 & nd & nd & $n d$ & 48 & $n d$ & 27 \\
\hline & 21.22 & 28 & $n d$ & 40 & nd & nd & nd & 49 & $n d$ & 33 \\
\hline & 27.82 & 28 & nd & 44 & $n d$ & nd & nd & 59 & $n d$ & 39 \\
\hline \multirow{4}{*}{ Air/CH4 } & 0.00 & 25 & nd & 26 & $n \mathrm{He}$ & nd & $n \mathrm{He}$ & 35 & 585 & 21 \\
\hline & 3.78 & 28 & nd & 26 & 625 & nd & $n \mathrm{He}$ & 43 & 116 & 24 \\
\hline & 21.00 & 27 & nd & 35 & 180 & nd & $\mathrm{nHe}$ & 56 & 535 & 30 \\
\hline & 26.92 & 28 & $n d$ & 36 & 202 & nd & $\mathrm{nHe}$ & 57 & 530 & 34 \\
\hline
\end{tabular}

nd $=$ no data

$n$ He $=$ Helium not detected 
Figure 11. Effect of injection campaigns on tetrachloroethylene (PCE) levels in soil gas.

\section{PCE in Soil Gas}

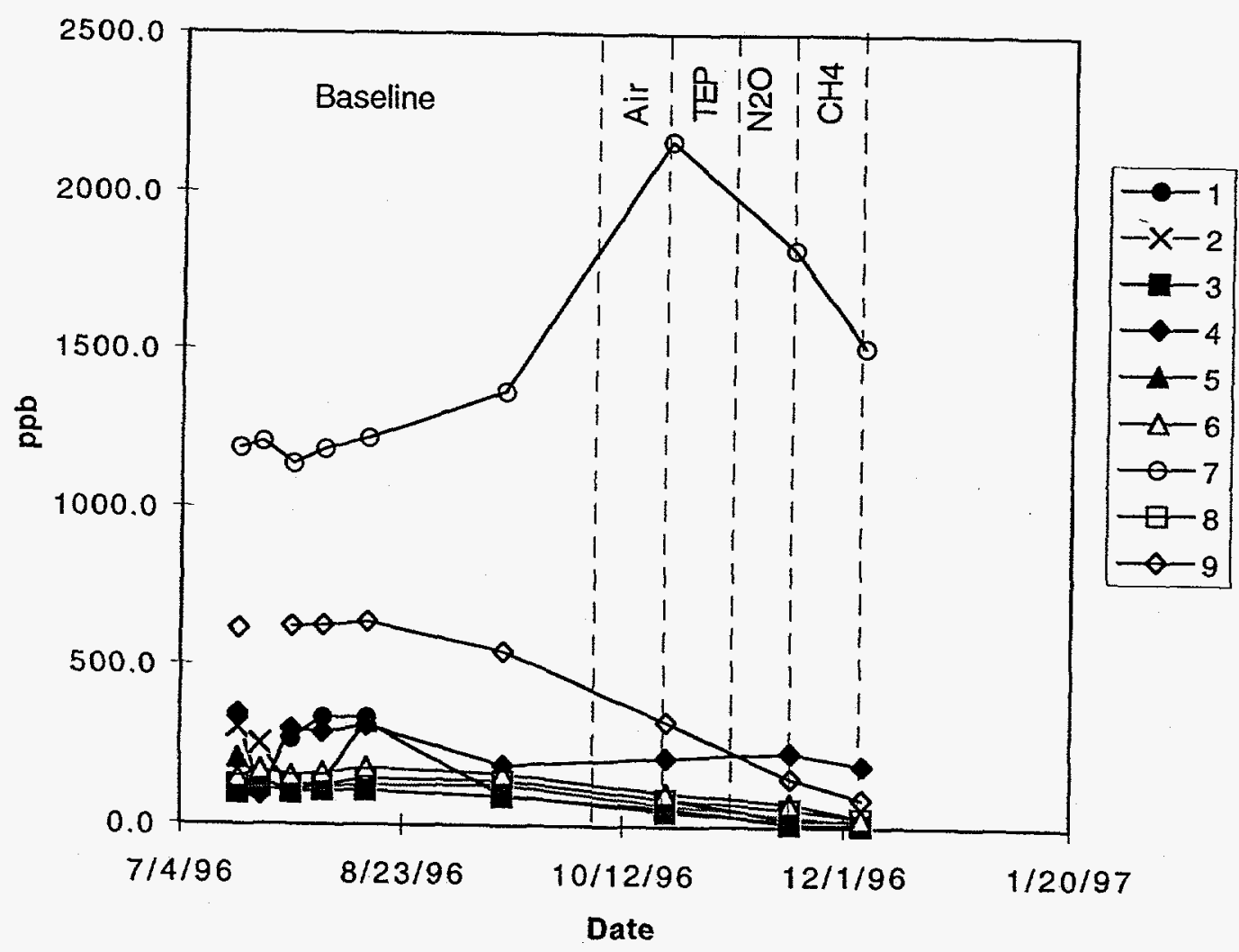


Figure 12. Effect of injection campaigns on trichloroethylene (TCE) levels in soil gas

\section{TCE in Soil Gas}

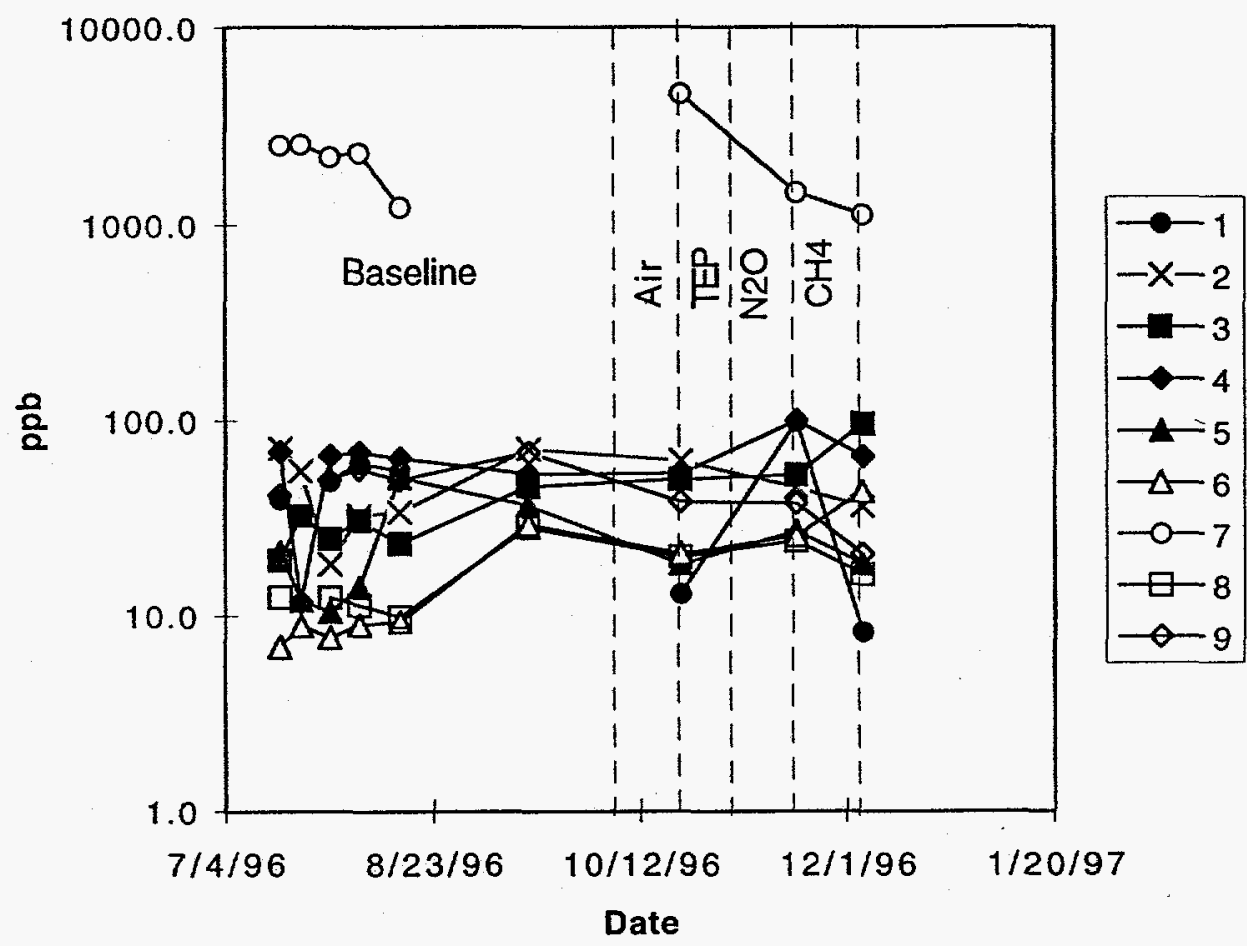


The most clear-cut results are seen in the case of tetrachloroethylene (Fig. 11). At most piezometers, slight declines in PCE levels were seen near the end of baseline measurements, but the rate of decline increased as a result of air injection. Nutrient addition appeared to have relatively little effect on the rate of PCE degradation, except at the location with the highest PCE levels (DOB-BV7). Here PCE levels increased prior to and during air injection, but declined during subsequent measurements. Since oxygen/carbon dioxide levels at this piezometer were lowest and respiration rate was highest after TEP injection, it appears likely that PCE degradation was stimulated by phosphate enrichment, and that sufficient phosphate was introduced to allow continued microbial activity during subsequent injection campaigns. It is possible that the effect of phosphate enrichment was masked by carbon limitation at the remaining piezometers, which all had lower PCE levels. Based on linear regression analysis of data collected during air and air/nutrient injection, a mean PCE degradation rate of $1.7 \mathrm{ppb} /$ day was calculated (DOB-BV7 was excluded from this estimate due to its atypically high contaminant levels). If average quantities of individual VOC's (Appendix 2) remaining in soil gas at the end of the study are summed, an estimated average VOC content of $211 \mathrm{ppb}$ is obtained (vinyl chloride levels are assumed negligible, in accordance with preliminary soil analysis results). This would yield an approximate minimum cleanup time of 124 days (4 months).

There was a slight increase in PCE degradation rates at DOB-BV4, 6, 7, and 8 during methane injection. This might indicate that the addition of this carbon source stimulated the development of methanotrophic bacteria capable of carrying out a cometabolic degradation of chlorinated solvents. Methane supplementation; however, was relatively brief and it is possible that more pronounced effects would have been evident after more prolonged injection.

TCE levels at DOB-BV7 also decreased as a result of nutrient injection, but the only other substantial net decreases in TCE content during the study were seen at DOB-BV1 and 9. It is suggestive that these were all in well-aerated locations, in which microbial populations could be expected to carry out a complete degradation of PCE. At poorly aerated locations, an anaerobic pathway (PCE $\rightarrow$ TCE $\rightarrow$ DCE $\rightarrow$ VC) might predominate, particularly in the intervals between injection campaigns. Hence a lack of decline, and in some cases, a buildup of TCE and other intermediates might occur. This idea is supported by the fact that 1,1-DCE levels fluctuated erratically at most piezometers (Appendix 2).

Surface emissions. Prior to commencement of the study, projected VOC emissions from the soil surface were calculated to be negligible. This was verified by actual measurements using a B \& $\mathrm{K}$ infrared photoacoustic analyzer and flux chamber. Raw data are shown in Appendix 3. 
Values for PCE, TCE, vinyl chloride, and diesel range hydrocarbons showed little change whether or not the injection system was operating. Similar values were seen when the instrument was not connected to the flux chamber (sampling atmosphere). It therefore appears that the readings are within the noise range and surface emissions are indeed negligible. In the absence of detectable emissions, an emission rate was not calculated.

\section{Groundwater measurements}

Dissolved nutrients. Two of the most commonly limiting nutrients for microbial growth are nitrogen and phosphorus. Analyses of nutrient levels in groundwater samples from monitoring wells immediately surrounding the DOSB (see Fig. 5 for well locations) show that, while substantial amounts of nitrate are present in all wells, phosphate is in most cases undetectable (Table 5). This supports the idea that, in the presence of adequate oxygen and carbon, microbial metabolism could be phosphate-limited at the site. However, as suggested previously, the addition of phosphate might have little effect on bacterial activity once carbon becomes limiting. Chloride concentrations were highest in the closest downgradient or sidegradient wells to the solvent contamination, i.e. DOB-2, 11, 13, 14. All the wells except DOB-3 had chloride concentrations above normal background for SRS, indicating that DOB-3 may be the only well not currently or formerly contaminated. This would suggest that a large amount of natural biodegradation of solvent has already taken place, since chloride is produced as an end product of the biodegradation of chlorinated solvents. This is similar to findings in M-Area and the SRS Sanitary Landfill.

Sulfate levels are substantially higher in downgradient wells DOB-11 and 14 . This likely indicates the presence (and degradation of) petroleum hydrocarbons in these locations.

Water quality parameters. Temperature, dissolved oxygen, $\mathrm{pH}$, redox potential, and conductivity were measured in monitoring wells during the baseline period and following each injection campaign. Data are shown in Table 6. It is apparent that the downgradient wells DOB- 11, 13, and 14 contained less dissolved oxygen than did the remaining wells, suggesting that the presence of contaminants has stimulated microbial metabolic activity. DOB-11 (screen depth 18.7 - 23.7') and 14 (screen depth 11.7 - 16.7') had less oxygen than DOB-13 (screen depth 18.5 $\left.-23.5^{\prime}\right)$. Together with the sulfate data, this suggests that the plume of readily oxidized substrates, (e.g. petroleum hydrocarbons) does not extend to as great a depth in the vicinity of the latter two wells. DOB-11, located well within the plume, also had the lowest redox potential (consistent with its low oxygen levels). DOB-11 and 14 gave consistently higher conductivity readings, indicating the presence of more dissolved materials. 
D-Area Oil Seepage Basin

In Situ Bioremediation Optimization Test

Final Report
WSRC-MS-96-0797, Rev. 0

Jan. 24, 1997

Table 5. Nutrient levels in groundwater.

\begin{tabular}{|c|c|c|c|c|c|c|c|}
\hline \multirow[b]{2}{*}{ Well } & \multirow[b]{2}{*}{ Date } & \multirow[b]{2}{*}{ Injection } & \multicolumn{5}{|c|}{ ppm } \\
\hline & & & Chloride & Nitrite & Nitrate & Phosphate & Sulfate \\
\hline DOB 2 & $7 / 19 / 96$ & OFF & 5.203 & bdl & 2.293 & bdl & 11.125 \\
\hline DOB 2 & $7 / 24 / 96$ & OFF & 4.401 & bdl & 2.664 & bdl & 7.331 \\
\hline DOB 2 & $9 / 20 / 96$ & OFF & 2.228 & bdl & 2.442 & bdl & 5.835 \\
\hline DOB 2 & $10 / 9 / 96$ & AIR & 2.748 & bdl & 2.983 & 0.069 & 6.813 \\
\hline DOB 2 & $10 / 31 / 96$ & AIR/TEP & 2.874 & bdl & 1.992 & bdl & 3.733 \\
\hline $\mathrm{DOB} 2$ & $11 / 15 / 96$ & AlR/N2O & 3.418 & bdl & 3.205 & 0.393 & 5.739 \\
\hline DOB 2 & $11 / 27 / 96$ & AlRICH4 & 3.751 & bdl & 3.139 & 0.334 & 5.907 \\
\hline DOB 3 & $7 / 19 / 96$ & OFF & 0.990 & bdl & 2.960 & 0.352 & 3.856 \\
\hline DOB 3 & $7 / 24 / 96$ & OFF & 0.905 & bd! & 3.064 & bd! & 4.176 \\
\hline DOB 3 & $9 / 20 / 96$ & OFF & 1.365 & bdl & 3.594 & bdl & 3.260 \\
\hline DOB 3 & $10 / 9 / 96$ & AIR & 1.703 & bdl & 4.077 & bdl & 4.077 \\
\hline DOB 3 & $10 / 31 / 96$ & AIR/TEP & 1.330 & bdl & 2.446 & bdl & 2.502 \\
\hline DOB 3 & $11 / 15 / 96$ & AIR/N2O & 1.683 & bdl & 3.582 & bdl & 3.566 \\
\hline DOB 3 & $11 / 27 / 96$ & AIR/CH4 & 2.444 & bdl & 3.567 & bdl & 3.621 \\
\hline DOB 4 & $7 / 12 / 96$ & OFF & 2.013 & bdl & 2.832 & bdl & 27.374 \\
\hline DOB 4 & $7 / 19 / 96$ & OFF & 4.307 & bdl & 4.115 & bdl & 4.756 \\
\hline DOB 4 & $7 / 24 / 96$ & OFF & 4.213 & bdl & 4.155 & bdl & 4.737 \\
\hline DOB 4 & $9 / 20 / 96$ & OFF & 3.580 & bdl & 3.476 & bdil & 4.088 \\
\hline DOB 4 & $10 / 9 / 96$ & AIR & 3.590 & bdl & 4.576 & bdl & 4.931 \\
\hline $\mathrm{DOB} 4$ & $10 / 31 / 96$ & AIR/TEP & 3.864 & bdl & 2.552 & bdl & 2.473 \\
\hline DOB 4 & $11 / 15 / 96$ & AIR/N2O & 3.007 & bdl & 4.147 & bdl & 4.125 \\
\hline $\mathrm{DOB} 4$ & $11 / 27 / 96$ & AIR/CH4 & 4.223 & bdl & 4.162 & bdl & 4.158 \\
\hline DOB 5 & $7 / 12 / 96$ & OFF & 2.711 & bdl & 3.267 & bdl & 9.548 \\
\hline DOB 5 & $7 / 19 / 96$ & OFF & 2.973 & bdl & 3.402 & bdl & 7.918 \\
\hline DOB 5 & $7 / 24 / 96$ & OFF & 3.225 & bdl & 3.613 & bdl & 6.720 \\
\hline DOB 5 & $9 / 20 / 96$ & OFF & 3.499 & bdl & 3.553 & bdl & 4.723 \\
\hline DOB 5 & $10 / 9 / 96$ & AIR & 0.668 & 0.372 & 0.682 & bdl & 9.534 \\
\hline DOB 5 & $10 / 31 / 96$ & AIR/TEP & 4.329 & bdl & 2.401 & bdl & 2.441 \\
\hline DOB 5 & $11 / 15 / 96$ & AIR/N2O & 3.142 & bdl & 4.140 & bdl & 4.009 \\
\hline DOB 5 & $11 / 27 / 96$ & AlR/CH4 & 4.383 & bdl & 4.355 & bdl & 3.255 \\
\hline DOB 11 & $7 / 19 / 96$ & OFF & 1.890 & bdl & 2.730 & bdl & 26.909 \\
\hline DOB 11 & $7 / 24 / 96$ & OFF & 2.144 & bdl & 3.325 & bol & 26.436 \\
\hline DOB 11 & $9 / 20 / 96$ & OFF & 2.636 & bdl & 1.165 & bdl & 18.326 \\
\hline DOB 11 & $10 / 9 / 96$ & AIR & 2.102 & 5.171 & 0.831 & bdl & 18.667 \\
\hline DOB 11 & $10 / 31 / 96$ & AIR/TEP & 2.640 & bdl & 1.165 & bdl & 8.985 \\
\hline DOB 11 & $11 / 15 / 96$ & AIR/N2O & 2.242 & bdl & 0.636 & bol & 15.435 \\
\hline DOB 11 & $11 / 27 / 96$ & AlR/CH4 & 3.106 & bdl & 0.358 & bdl & 14.848 \\
\hline DOB 13 & $7 / 12 / 96$ & OFF & 4.023 & bdl & 3.489 & bdl & 7.283 \\
\hline DOB 13 & $7 / 19 / 96$ & OFF & 4.245 & bdl & 3.498 & bdl & 7.196 \\
\hline DOB 13 & $7 / 24 / 96$ & OFF & 4.103 & bdl & 3.622 & bdl & 6.802 \\
\hline DOB 13 & $9 / 20 / 96$ & OFF & 3.308 & bdl & 2.878 & bdl & 7.514 \\
\hline $\mathrm{DOB} 13$ & $10 / 9 / 96$ & AIR & 3.678 & bdl & 3.769 & bdl & 8.605 \\
\hline DOB 13 & $10 / 31 / 96$ & AIR/TEP & 4.900 & bdl & 2.453 & bdl & 4.183 \\
\hline DOB 13 & $11 / 15 / 96$ & AIR/N2O & 3.015 & bdl & 3.404 & bdl & 7.207 \\
\hline DOB 13 & $11 / 27 / 96$ & AIR/CH4 & 3.775 & bdl & 3.833 & bdl & 6.786 \\
\hline DOB 14 & $7 / 19 / 96$ & OFF & 3.039 & bdl & 0.845 & bdl & 24.310 \\
\hline DOB 14 & $7 / 24 / 96$ & OFF & 3.413 & bd! & 0.844 & bdl & 23.851 \\
\hline DOB 14 & $9 / 20 / 96$ & OFF & 3.100 & bdl & 1.128 & bdl & 23.498 \\
\hline DOB 14 & $10 / 9 / 96$ & AIR & 3.414 & bdl & 1.628 & bdl & 24.129 \\
\hline DOB 14 & $10 / 31 / 96$ & AIR/TEP & 3.607 & bdl & 1.558 & bd! & 10.369 \\
\hline DOB 14 & $11 / 15 / 96$ & AIR/N2O & 2.793 & bdl & 1.882 & bdl & 21.853 \\
\hline DOB 14 & $11 / 27 / 96$ & AlR/CH4 & 3.103 & bdl & 1.664 & bdl & 22.728 \\
\hline
\end{tabular}


D-Area Oil Seepage Basin

In Situ Bioremediation Optimization Test

WSRC-MS-96-0797, Rev. 0

Final Report

Jan. 24, 1997

Table 6. Water quality data.

\begin{tabular}{|c|c|c|c|c|c|c|c|c|c|c|}
\hline Well & Date & Status & Campaign & Temp, oc & Do, mg/l & DO, \% Sat & $\mathrm{pH}$ & Eh, $m V$ & Cond. & Notes \\
\hline DOB2 & $7 / 19 / 96$ & OFF & Baseline & 21.95 & 4.29 & 49.2 & 5.35 & 350 & 0.0582 & \\
\hline $\mathrm{DOB2}$ & $7 / 24 / 96$ & OFF & Baseline & 19.26 & 4.78 & 52.4 & 4.71 & 320 & 0.0479 & \\
\hline DOB2 & $9 / 20 / 96$ & OFF & Baseline & 19.43 & 4.71 & 51.9 & 4.69 & 306 & 0.0328 & \\
\hline DOB2 & $10 / 9 / 96$ & ON & Air & 19.57 & 4.68 & 51.8 & 4.61 & 408 & 0.0339 & \\
\hline DOB2 & $10 / 31 / 96$ & ON & $\mathrm{Air}+\mathrm{TEP}$ & 19.95 & 4.45 & 48.9 & 4.48 & 443 & 0.0362 & \\
\hline DOB2 & $11 / 15 / 96$ & ON & $\mathrm{Air}+\mathrm{N} 2 \mathrm{O}$ & 19.24 & 5.41 & 59.5 & 4.59 & 428 & 0.0373 & \\
\hline DOB2 & $11 / 27 / 96$ & ON & $\mathrm{Air}+\mathrm{CH} 4$ & & & & & & & maffunction \\
\hline DOB3 & $7119 / 96$ & OFF & Baseline & 27.97 & 7.15 & 91.8 & 5.81 & 360 & 0.0313 & \\
\hline DO83 & $7 / 24 / 96$ & OFF & Baseline & 22.57 & 7.37 & 86.1 & 5.33 & 392 & 0.0283 & \\
\hline DOB3 & $9 / 20 / 96$ & OFF & Baseline & 23.25 & 6.96 & 82.7 & 5.13 & 468 & 0.0272 & \\
\hline DOB 3 & $10 / 9 / 96$ & ON & Air & 22.98 & 7.08 & 83.2 & 5.17 & 415 & 0.0281 & \\
\hline DOB3 & $10 / 31 / 96$ & ON & $\mathrm{Air}+\mathrm{TEP}$ & 22.42 & 6.72 & 77.4 & 5.24 & 409 & 0.0289 & \\
\hline DOB3 & $11 / 15 / 96$ & ON & $\mathrm{Air}+\mathrm{N} 2 \mathrm{O}$ & 20.85 & 10.05 & 115.4 & 5.29 & 392 & 0.0305 & going dry \\
\hline DOB3 & $11 / 27 / 96$ & ON & $\mathrm{Air}+\mathrm{CH} 4$ & 20.71 & 9.98 & 112.1 & 4.99 & 445 & 0.0327 & going dry \\
\hline DOB4 & $7 / 12 / 96$ & OFF & Baseline & & 8.59 & & 5.07 & 311 & 0.056 & \\
\hline DOB4 & $7 / 19 / 96$ & OFF & Baseline & 19.92 & 5.07 & 55.8 & 5.4 & 372 & 0.0471 & \\
\hline DOB4 & $7 / 24 / 96$ & OFF & Baseline & 20.29 & 5.23 & 58.5 & 4.86 & 413 & 0.0476 & \\
\hline DOB4 & $9 / 20 / 96$ & OfF & Baseline & 21.33 & 4.84 & 55.3 & 4.68 & 486 & 0.0383 & \\
\hline DOB4 & $9 / 26 / 96$ & OFF & Baseline & 21.53 & 4.99 & 57.4 & 4.72 & 441 & 0.043 & \\
\hline DOB4 & $10 / 9 / 96$ & ON & Air & 21.49 & 5.11 & 58.5 & 4.61 & 496 & 0.0383 & \\
\hline DOB4 & $10 / 31 / 96$ & ON & $\mathrm{Air}+\mathrm{TEP}$ & 21.56 & 5.19 & 58.5 & 4.63 & 430 & 0.0391 & \\
\hline DOB4 & $11 / 15 / 96$ & ON & $\mathrm{Air}+\mathrm{N2O}$ & 20.78 & 6.18 & 70.2 & 4.75 & 454 & 0.0395 & \\
\hline DOB4 & $11 / 27 / 96$ & ON & $\mathrm{Air}+\mathrm{CH}_{4}$ & 21.01 & 5.29 & 60.1 & 4.54 & 476 & 0.04 & \\
\hline DOB5 & $7 / 19 / 96$ & OFF & Baseline & 21.07 & 459 & 52.2 & 5.53 & 383 & 0.0525 & \\
\hline DOB5 & $7 / 24 / 96$ & OFF & Baseline & 21.6 & 4.66 & 53.5 & 4.92 & 386 & 0.051 & \\
\hline DOB5 & $9 / 20 / 96$ & OFF & Baseline & $21: 54$ & 3.97 & 45.7 & 4.93 & 435 & 0.0435 & \\
\hline DOB5 & $9 / 26 / 96$ & OFF & Baseline & 22.81 & 4.1 & 48.4 & 5.05 & 408 & 0.0509 & \\
\hline DOB5 & $10 / 1 / 96$ & ON & In situ resp. 1 & 21.86 & 5.9 & 67.4 & 4.83 & 413 & 0.037 & \\
\hline 0085 & $10 / 4 / 96$ & ON & In situ reso. I & 22.02 & 5.7 & 65.5 & 4.88 & 407 & 0.0362 & \\
\hline DOB5 & $10 / 9 / 96$ & ON & Air & 22.05 & 5.64 & 65 & 4.84 & 455 & 0.0263 & \\
\hline DOBS & $10 / 31 / 96$ & ON & $\mathrm{Air}+\mathrm{TEP}$ & 21.98 & 4.07 & 46.5 & 5.08 & 374 & 0.0464 & \\
\hline DOBS & $11 / 15 / 96$ & $\mathrm{ON}$ & Air $+\mathrm{N} 2 \mathrm{O}$ & 21.19 & 4.61 & 53.1 & 5.2 & 422 & 0.0478 & \\
\hline DOB5 & $11 / 27 / 96$ & ON & $\mathrm{Air}+\mathrm{CH}_{4}$ & 21.13 & 4.68 & 53.1 & 5.09 & 419 & 0.0474 & \\
\hline DOB11 & $7 / 12196$ & OFF & Baseline & & 1.8 & & 6.58 & 60 & 0.328 & \\
\hline DOB11 & $7 / 19 / 96$ & OFF & Baseline & 21.07 & 1.14 & 13 & 7.27 & 171 & 0.327 & \\
\hline DOB11 & $7 / 24 / 96$ & OFF & Baseline & 21.26 & 1.61 & 18.3 & 6.59 & 156 & 0.318 & \\
\hline DOB11 & $9 / 20 / 96$ & OFF & Baseline & 21.7 & 0.66 & 7.4 & 6.49 & 276 & 0.179 & \\
\hline DOB11 & $9 / 26 / 96$ & OFF & Baseline & 22.43 & 0.64 & 7.3 & 6.57 & 275 & 0.196 & \\
\hline DOB11 & $10 / 1 / 96$ & ON & In situ resp. 1 & 21.5 & 0.63 & 7.2 & 6.51 & 251 & 0.169 & \\
\hline DOB 11 & $10 / 4196$ & ON & In situ resp. I & 21.42 & 0.6 & 6.8 & 6.52 & 248 & 0.166 & \\
\hline 00811 & $10 / 9 / 96$ & ON & Air & 21.31 & 0.57 & 6.5 & 6.45 & 256 & 0.163 & \\
\hline DOB11 & $10 / 31 / 96$ & $\mathrm{ON}$ & $\mathrm{Air}+\mathrm{TEP}$ & 21.45 & 0.73 & 8.2 & 6.44 & 282 & 0.164 & \\
\hline DOB11 & $11 / 15 / 96$ & ON & $\mathrm{Air}+\mathrm{N} 2 \mathrm{O}$ & 18.57 & 0.86 & 9.4 & 6.5 & 247 & 0.159 & \\
\hline DOB11 & $11 / 27 / 96$ & ON & $\mathrm{Air}+\mathrm{CH} 4$ & 19.2 & 0.86 & 9.2 & 6.42 & 269 & 0.158 & \\
\hline DOB13 & $7 / 12 / 96$ & OFF & Baseline & & 6.9 & & 5 & 439 & 0.055 & \\
\hline 00813 & $7 / 19 / 96$ & OFF & Baseline & 18.85 & 4.23 & 45.9 & 5.66 & 362 & 0.0525 & \\
\hline DOB13 & $7 / 24 / 96$ & OFF & Baseline & 18.87 & 4.61 & 50.3 & 5.15 & 314 & 0.0517 & \\
\hline Do813 & $9 / 20 / 96$ & OFF & Baseline & 18.88 & 2.45 & 26.9 & 4.84 & 432 & 0.0455 & \\
\hline DOB 13 & $9 / 26 / 96$ & OFF & Baseline & 19.12 & 2.36 & 25.7 & 4.9 & 429 & 0.0512 & \\
\hline $\mathrm{DOB} 13$ & $10 / 196$ & ON & In situ resp. I & 18.76 & 3.58 & 38.7 & 4.86 & 445 & 0.0447 & \\
\hline DOB 13 & $10 / 4 / 96$ & ON & In situ resp il & 18.67 & 3.52 & 38 & 4.86 & 424 & 0.0446 & \\
\hline DOB13. & $10 / 9 / 96$ & ON & Air & 18.72 & 3.56 & 38.6 & 4.81 & 443 & 0.0451 & \\
\hline DOB 13 & $10 / 3196$ & ON & $\mathrm{Air}+$ TEP & 19.23 & 3.62 & 39.2 & 4.77 & 452 & 0.0475 & \\
\hline 00813 & $11 / 15196$ & ON & $\mathrm{Air}+\mathrm{N}_{2} \mathrm{O}$ & 17.58 & 4.16 & 44.3 & 4.83 & 428 & 0.0447 & \\
\hline DOB13 & $11 / 27 / 96$ & ON & $\mathrm{Air}+\mathrm{CH}_{4}$ & 18.42 & 1.46 & 15.8 & 4.48 & 487 & 0.0749 & \\
\hline DOB14 & $7 / 19 / 96$ & OFF & Baseline & 19.27 & 1.13 & 12.1 & 5.28 & 359 & 0.0806 & \\
\hline DOB 14 & $7 / 24 / 96$ & OFF & Baseline & 19.23 & 1.77 & 19.4 & 4.78 & 322 & 0.0813 & \\
\hline DOB14 & $9 / 20196$ & OFF & Baseline & 19.48 & 0.87 & 9.5 & 4.54 & 421 & 0.0706 & \\
\hline DOB 14 & $9 / 26 / 96$ & OFF & Baseline & 19.88 & 0.94 & 10.3 & 4.6 & 420 & 0.079 & \\
\hline DOB14 & $10 / 1 / 96$ & ON & In situ reso. I & 19.41 & 0.66 & 7.4 & 4.53 & 448 & 0.0692 & \\
\hline DOB14 & $10 / 4 / 96$ & $\mathrm{ON}$ & In situ resp. I & 19.31 & 0.83 & 9.1 & 4.53 & 430 & 0.0683 & \\
\hline DOB14 & $10 / 9 / 96$ & ON & Air & 19.35 & 0.74 & 8 & 4.52 & 447 & 0.0678 & \\
\hline $\mathrm{DOB} 14$ & $10 / 31 / 96$ & ON & $\mathrm{Air}$ + TEP & 19.51 & 0.86 & 9.3 & 4.5 & 465 & 0.0682 & \\
\hline 00814 & $11 / 15 / 96$ & ON & $\mathrm{Air}+\mathrm{N2O}$ & 18.23 & 1.13 & 12.3 & 4.53 & 439 & 0.068 & \\
\hline DOB14 & $11 / 27 / 96$ & ON & $\mathrm{Air}+\mathrm{CH}_{4}$ & 18.42 & 1.46 & 15.8 & 4.48 & 487 & 0.0749 & \\
\hline
\end{tabular}


There was a tendency in DOB-11 and 14 for dissolved oxygen levels to decline during baseline measurements, reach a minimum during air injection, then rise during subsequent campaigns. This is consistent with the idea that microbial metabolic activity (contaminant degradation) was significantly stimulated by air injection. The progressively lesser degree of stimulation by air plus the various nutrients suggests that limitation by a nutrient other than phosphorus, nitrogen, or methane was curtailing metabolic rates. Note the tendency for conductivity to decline with time in these wells. This suggests that aeration and the consequent increase in redox potential may have reduced the mobility of metal contaminants emanating from the basin.

There was little or no change in $\mathrm{pH}$ ( which was relatively low in most wells) as a result of the injections. This probably relates to the relatively small influence of aeration at the groundwater monitoring points due to their distance from the horizontal wells. At the SRS Sanitary Landfill, $\mathrm{pH}$ increases of 1 unit or more have been observed as a result of air injection (Hazen, 1996), and it is likely that similar changes occurred in the more intensively aerated regions of the DOSB.

Volatile organics in groundwater. Analyses of groundwater samples also indicated a tendency for chlorinated solvents to decrease with time in the downgradient wells DOB 11, 13, and 14, dropping below detection limits after air injection (Table 7). Except in the case of PCE and TCE in DOB-14, the data suggest that degradation of these VOC's was already underway and that air injection had little effect. The presence of small amounts of PCE in DOB-5 suggests that this well receives some influence from the basin.

Petroleum hydrocarbons and PAH's. Table 8 show data gathered during analysis of hydrocarbons in groundwater samples. Odd-numbered compounds (other than C15) were not quantified. All wells contained substantial amounts of petroleum hydrocarbons. In the case of wells DOB 2,3, and 5, this is almost certainly due to their shallow screen depth (Table 1). DOB-4 may also be influenced at times by a hydrocarbon film at the top of the saturated zone, or may be subject to influence from the basin because of its location. In most cases, the downgradient wells DOB-13 and 14 contained the highest total hydrocarbon levels. The amounts compounds present shifted in all wells during the study. This could relate to changes in water table level. Types of compounds present also shifted, and in the those wells expected to receive the most influence from the basin (DOB-4,11, 13, and 14), there appears to have been a loss of higher molecular weight components during the study. In several cases, high molecular weight components disappeared after injection of air alone. This might indicate microbial breakdown of these substances. 
D-Area Oil Seepage Basin

WSRC-MS-96-0797, Rev. 0

In Situ Bioremediation Optimization Test

Jan. 24, 1997

Final Report

Table 7. Volatile organic compounds in groundwater.

\begin{tabular}{|c|c|c|c|c|c|c|c|c|}
\hline Well & Date & | Campaign & IPCE & TCE & cis-DCE & Freon 13 & $\begin{array}{c}\text { Vinyl } \\
\text { Chloride }\end{array}$ & Freon 12 \\
\hline \multirow{6}{*}{ Blank } & $7 / 19 / 96$ & Baseline & $<5.0$ & $<5.0$ & $<5.0$ & $<5.0$ & $<5.0$ & $<5.0$ \\
\hline & $7 / 24 / 96$ & Baseline & $<5.0$ & $<5.0$ & $<5.0$ & $<5.0$ & $<5.0$ & $<5.0$ \\
\hline & $9 / 20 / 96$ & Baseline & $<5.0$ & $<5.0$ & $<5.0$ & $<5.0$ & $<5.0$ & 2.9 \\
\hline & $10 / 31 / 96$ & TEP & $<5.0$ & $<5.0$ & $<5.0$ & $<5.0$ & $<5.0$ & $<5.0$ \\
\hline & $11 / 16 / 96$ & $\mathrm{~N} 2 \mathrm{O}$ & $<5.0$ & $<5.0$ & $<5.0$ & $<5.0$ & $<5.0$ & $<5.0$ \\
\hline & $11 / 27 / 96$ & $\mathrm{CH} 4$ & $\#$ & $<5.0$ & $<5.0$ & $<5.0$ & $<5.0$ & $<5.0$ \\
\hline \multirow[t]{7}{*}{$\overline{D O B} 2$} & $7 / 19 / 96$ & Baseline & $<5.0$ & $<5.0$ & $<5.0$ & $<5.0$ & $<5.0$ & $<5.0$ \\
\hline & $7 / 24 / 96$ & Baseline & $<5.0$ & $<5.0$ & $<5.0$ & $<5.0$ & $<5.0$ & $<5.0$ \\
\hline & $9 / 20 / 96$ & Baseline & $<5.0$ & $<5.0$ & $<5.0$ & $<5.0$ & $<5.0$ & $<5.0$ \\
\hline & $10 / 9 / 96$ & AIR & $<5.0$ & $<5.0$ & $<5.0$ & $<5.0$ & $<5.0$ & $<50$ \\
\hline & $10 / 31 / 96$ & TEP & $<5.0$ & $<5.0$ & $<5.0$ & $<5.0$ & $<5.0$ & $<5.0$ \\
\hline & $11 / 16 / 96$ & N2O & $<5.0$ & $<5.0$ & $\#$ & $<5.0$ & $<5.0$ & $<5.0$ \\
\hline & $11 / 27 / 96$ & $\mathrm{CH} 4$ & $<5.0$ & $<5.0$ & $<5.0$ & $<5.0$ & $<5.0$ & $<5.0$ \\
\hline \multirow[t]{7}{*}{ DOB 3} & $7 / 19 / 96$ & Baseline & $<5.0$ & $<5.0$ & $<5.0$ & $<5,0$ & $<5.0$ & $<5.0$ \\
\hline & $7 / 24 / 96$ & Baseline & $<5.0$ & $<5.0$ & $<5.0$ & $<5.0$ & $<5.0$ & $<5.0$ \\
\hline & $9 / 20 / 96$ & Baseline & $<5.0$ & $<5.0$ & $<5.0$ & $<5.0$ & $<5.0$ & 5.5 \\
\hline & $10 / 9 / 96$ & AIR & $<5.0$ & $<5.0$ & $<5.0$ & $<5.0$ & $<5.0$ & $<5,0$ \\
\hline & $10 / 31 / 96$ & TEP & $7.8 \#$ & $<5.0$ & $<5.0$ & $<5.0$ & $<5.0$ & $<5.0$ \\
\hline & $11 / 16 / 96$ & $\mathrm{~N} 2 \mathrm{O}$ & $\#$ & $7.8 ?$ & $\#$ & $<5.0$ & $<5.0$ & $<5,0$ \\
\hline & $11 / 27 / 96$ & $\mathrm{CH} 4$ & $\#$ & $<5.0$ & $<5.0$ & $<5.0$ & $<5.0$ & $<5.0$ \\
\hline \multirow[t]{7}{*}{ DOB 4} & $7 / 19 / 96$ & Baseline & $<5.0$ & $<5.0$ & $<5.0$ & $<5.0$ & $<5.0$ & $<5.0$ \\
\hline & $7 / 24 / 96$ & Baseline & $<5.0$ & $<5.0$ & $<5.0$ & $<5.0$ & $<5.0$ & $<5.0$ \\
\hline & $9 / 20 / 96$ & Baseline & $<5.0$ & $<5.0$ & $<5.0$ & $<5.0$ & $<5.0$ & 2.65 \\
\hline & $10 / 9 / 96$ & AIR & $<5.0$ & $<5.0$ & $<5.0$ & $<5.0$ & $<5.0$ & $<5.0$ \\
\hline & $10 / 31 / 96$ & TEP & $<5.0$ & $<5.0$ & $<5.0$ & $<5.0$ & $<5.0$ & $<5.0$ \\
\hline & $11 / 16 / 96$ & $\mathrm{~N} 2 \mathrm{O}$ & $\#$ & $<5.0$ & $<5.0$ & $<5.0$ & $<5.0$ & $<5.0$ \\
\hline & $11 / 27 / 96$ & $\mathrm{CH} 4$ & $\#$ & $<5.0$ & $<5.0$ & $<5.0$ & $<5.0$ & $<5.0$ \\
\hline \multirow[t]{8}{*}{ DOB 5} & $7 / 12 / 96$ & Baseline & 5.7 & $<5.0$ & $<5.0$ & $>5.0 \#$ & $>5.0 \#$ & $>5.0$ \\
\hline & $7 / 19 / 96$ & Baseline & 8 & $<5.0$ & $<5.0$ & $<5.0$ & $<5.0$ & $<5.0$ \\
\hline & $7 / 24 / 96$ & Baseline & 5.4 & $<5.0$ & $<5.0$ & $<5.0$ & $<5.0$ & $<5.0$ \\
\hline & $9 / 20 / 96$ & Baseline & $<5.0$ & $<5.0$ & $<5.0$ & $<5.0$ & $<5.0$ & 2.7 \\
\hline & $10 / 9 / 96$ & AIR & $<5.0$ & $<5.0$ & $<5.0$ & $<5.0$ & $<5.0$ & $<5.0$ \\
\hline & $10 / 31 / 96$ & TEP & 5.4 & $8.8 \#$ & $<5.0$ & $<5.0$ & $<5.0$ & $<5.0$ \\
\hline & $11 / 16 / 96$ & $\mathrm{~N} 20$ & $\#$ & $<5.0$ & $<5.0$ & $<5.0$ & $<5.0$ & $<5.0$ \\
\hline & $11 / 27 / 96$ & $\mathrm{CH} 4$ & $\#$ & $<5.0$ & $<5.0$ & $<5.0$ & $<5.0$ & $\#$ \\
\hline \multirow[t]{8}{*}{ DOB 11} & $7 / 12 / 96$ & Baseline & 11.2 & 45.7 & $123.3 \#$ & $>5.0 \#$ & 62.2 & $>5,0$ \\
\hline & $7 / 19 / 96$ & Baseline & 7.7 & 24.2 & 67.5 & $<5.0$ & 8.3 & $<5.0$ \\
\hline & $7 / 24 / 96$ & Baseline & 6 & 14.3 & 37.6 & $<5.0$ & $<5.0$ & $<5.0$ \\
\hline & $9 / 20 / 96$ & Baseline & $<5.0$ & $<5.0$ & 9.95 & $<5.0$ & $<5.0$ & $<5.0$ \\
\hline & $10 / 9 / 96$ & AIR & $<5.0$ & $<5.0$ & $<5.0$ & $<5.0$ & $<5.0$ & $<5,0$ \\
\hline & $10 / 31 / 96$ & TEP & $<5.0$ & $<5.0$ & $<5.0$ & $<5.0$ & $<5.0$ & $<5.0$ \\
\hline & $11 / 16 / 96$ & $\mathrm{~N} 2 \mathrm{O}$ & $<5.0$ & $<5.0$ & $<5.0$ & $<5.0$ & $<5.0$ & $<5,0$ \\
\hline & $11 / 27 / 96$ & $\mathrm{CH} 4$ & $<5.0$ & $<5.0$ & $<5.0$ & $<5.0$ & $<5.0$ & $<5.0$ \\
\hline \multirow[t]{7}{*}{$\overline{\mathrm{DOB} 13}$} & $7 / 12 / 96$ & Baseline & $<5.0$ & $<5.0$ & $<5.0$ & $>5.0$ \# & $>5.0$ \# & $>5.0 \#$ \\
\hline & $7 / 24 / 96$ & Baseline & $<5.0$ & $<5.0$ & $<5.0$ & $<5.0$ & $<5.0$ & $<5.0$ \\
\hline & $9 / 20 / 96$ & Baseline & $<5.0$ & 8.2 & $<5.0$ & $<5.0$ & $<5.0$ & 2.85 \\
\hline & $10 / 9 / 96$ & AIR & $<5.0$ & $<5.0$ & $<5.0$ & $<5.0$ & $<5.0$ & $<5.0$ \\
\hline & $10 / 31 / 96$ & TEP & $<5.0$ & $<5.0$ & $<5.0$ & $<5.0$ & $<5.0$ & $<5.0$ \\
\hline & $11 / 16 / 96$ & $\mathrm{~N} 2 \mathrm{O}$ & $\#$ & $<5.0$ & $<5.0$ & $<5.0$ & $<5.0$ & $<5.0$ \\
\hline & $11 / 27 / 96$ & $\mathrm{CH} 4$ & $\#$ & $<5.0$ & $<5.0$ & $<5.0$ & $<5.0$ & $<5.0$ \\
\hline \multirow[t]{7}{*}{ DOB 14} & $7 / 19 / 96$ & Baseline & 7.6 & 9.2 & 5.7 & $<5.0$ & $<5.0$ & $<5,0$ \\
\hline & $7124 / 96$ & Baseline & 10.2 & 14 & 5.3 & $<5.0$ & $<5.0$ & $<5.0$ \\
\hline & $9 / 20 / 96$ & Baseline & 8.55 & 16.3 & $<5.0$ & $<5.0$ & $<5.0$ & $<5.0$ \\
\hline & $10 / 9 / 96$ & AIR & $<5.0-$ & $<5.0$ & $<5.0$ & $<5.0$ & $<5.0$ & $<5.0$ \\
\hline & $10 / 31 / 96$ & TEP & $<5.0$ & $<5.0$ & $<5.0$ & $<5.0$ & $<5.0$ & $<5.0$ \\
\hline & $11 / 16 / 96$ & $\mathrm{~N} 2 \mathrm{O}$ & $\#$ & $<5.0$ & $<5.0$ & $<5.0$ & $<5.0$ & $<5.0$ \\
\hline & $11 / 27 / 96$ & $\mathrm{CH} 4$ & $\#$ & $<5.0$ & $<5.0$ & $<5.0$ & $<5.0$ & $<5.0$ \\
\hline
\end{tabular}

Note: Compounds below detection limits in all samples were: 1,2 DCB; 1,3 DCB; $1,3 D C B$;

1,3,5-trimethylbenzene; 2-chlomtoluene; n-propylbenzene; bromobenzene; xylenes;

ethylbenzene; chlorobenzene; toluene; benzene; carbon tetrachlaride; trans-DCE:

1,1-DCE; methylene chloride; chloroform; 1,1,1-TCA

$\#$ = does not meet qualifiers 
Table 8. Hydrocarbon analyses of groundwater samples.

\begin{tabular}{|c|c|c|c|c|c|c|c|c|c|c|c|c|c|c|c|c|c|}
\hline Well & Date & Campaign & $\begin{array}{l}\text { UNK } \\
6.98\end{array}$ & $\begin{array}{l}\text { UNK } \\
9.0\end{array}$ & 5.8 & $\mathrm{C}_{10}$ & C12 & C14 & C15 & C16 & C18 & C20 & $\mathrm{C} 22$ & C24 & C26 & C SUM & $\begin{array}{l}\text { UNKNOWN } \\
\text { SUM }\end{array}$ \\
\hline DOB-2 & $9 / 20 / 96$ & Baseline & 0.3 & 5.1 & 0.5 & 0.3 & 1.1 & 4.9 & 2.3 & 6.9 & 0.0 & 0.0 & 0.0 & $\mathrm{BDL}$ & $\mathrm{BDL}$ & 15.5 & 5.9 \\
\hline DOB-2 & $10 / 9 / 96$ & Air & 0.2 & 0.7 & 0.2 & 0.2 & 0.8 & 1.2 & 0.2 & 3.5 & 0.0 & 0.0 & 0.0 & $B D L$ & $\mathrm{BDL}$ & 5.9 & 1.1 \\
\hline DOB-2 & $10 / 31 / 96$ & Air/TEP & 0.2 & 2.6 & 0.7 & 0.2 & 0.8 & 38.7 & 5.2 & 37.5 & 0.0 & 0.0 & 0.0 & $\mathrm{BDL}$ & $\mathrm{BDL}$ & 82.4 & 3.5 \\
\hline DOB-2 & $11 / 15 / 96$ & Air/N2O & 0.2 & 3.1 & 0.4 & 0.2 & 1.7 & 3.9 & 2.3 & 2.7 & 0.0 & 0.0 & 0.0 & $B D L$ & $\overline{B D L}$ & 10.8 & 3.7 \\
\hline DOB-2 & $11 / 27 / 96$ & Air/CH4 & 0.4 & 17.0 & 1.1 & 0.4 & 4.9 & 5.6 & 6.1 & 6.3 & 0.0 & 0.0 & 0.0 & $\mathrm{BDL}$ & $\mathrm{BDL}$ & 23.3 & 18.4 \\
\hline DOB-3 & $9 / 20 / 96$ & Baseline & 0.2 & 6.9 & 1.1 & 0.2 & 0.5 & 17.1 & 5.0 & 6.6 & 0.0 & 0.0 & 0.0 & $\mathrm{BDL}$ & $\mathrm{BDL}$ & 29.4 & 8.2 \\
\hline DOB-3 & $10 / 9 / 96$ & Air & 0.1 & 4.2 & 0.4 & 0.1 & 1.7 & 6.8 & 4.4 & 15.5 & 0.0 & 0.0 & 0.0 & $\mathrm{BDL}$ & $\mathrm{BDL}$ & 28.5 & 4.7 \\
\hline DOB-3 & $10 / 31 / 96$ & Air/TEP & 0.2 & 3.7 & 0.4 & 0.2 & 0.8 & 43.7 & 3.2 & 51.0 & 0.0 & 0.0 & 0.0 & $\mathrm{BDL}$ & $\overline{B D L}$ & 98.9 & 4.3 \\
\hline $\mathrm{DOB}-3$ & $11 / 15 / 96$ & Air/N2O & 1.0 & 38.0 & 1.2 & 1.0 & 4.9 & 3.6 & 24.3 & 17.4 & 0.0 & 0.0 & 0.0 & $\mathrm{BDL}$ & $\mathrm{BDL}$ & 51.3 & 40.1 \\
\hline DOB-3 & $11 / 27 / 96$ & $\mathrm{Air} / \mathrm{CH} 4$ & 0.2 & 3.2 & 0.3 & 0.2 & 0.5 & 3.2 & 2.3 & 2.4 & 0.0 & 0.0 & 0.0 & $\mathrm{BDL}$ & $\mathrm{BDL}$ & 8.6 & 3.8 \\
\hline DOB-4 & $9 / 20 / 96$ & Baseline & 1.7 & 23.6 & 1.5 & 1.7 & 5.2 & 3.5 & 4.8 & 2.6 & 2.8 & 28.8 & 148.3 & $\mathrm{BDL}$ & $\overline{B D L}$ & 197.9 & 26.8 \\
\hline $\mathrm{DOB}-4$ & $10 / 9 / 96$ & Air & 0.4 & 4.9 & 0.5 & 0.4 & 1.7 & 0.9 & 0.9 & 2.9 & 0.0 & 0.0 & 0.0 & $B D L$ & BDL & 6.8 & 5.8 \\
\hline DOB-4 & $10 / 31 / 96$ & AirrTEP & 0.2 & 3.6 & 0.7 & 0.2 & 1.9 & 34.4 & 1.3 & 50.0 & 0.0 & 0.0 & 0.0 & $\mathrm{BDL}$ & $\overline{B D L}$ & 87.7 & 4.5 \\
\hline$D O B-4$ & $11 / 15 / 96$ & Air/N2O & 0.8 & 15.2 & 0.9 & 0.8 & 2.6 & 9.9 & 6.7 & 8.0 & 0.0 & 0.0 & 0.0 & $\mathrm{BDL}$ & $\mathrm{BDL}$ & 28.0 & 17.0 \\
\hline $\mathrm{DOB}-4$ & $11 / 27 / 96$ & Air $/ \mathrm{CH} 4$ & 0.2 & 2.8 & 0.4 & 0.2 & 0.3 & 0.8 & 2.1 & 2.7 & 0.0 & 0.0 & 0.0 & $B D L$ & $B D L$ & 8.0 & 3.4 \\
\hline DOB-5 & $9 / 20 / 96$ & Baseline & 0.2 & 4.3 & 11.4 & 0.2 & 2.2 & 5.6 & 0.1 & 2.0 & 2.0 & 4.3 & 3.3 & $\mathrm{BDL}$ & $\mathrm{BDL}$ & 19.7 & 15.9 \\
\hline DOB-5 & $10 / 9 / 96$ & Air & 0.2 & 5.6 & 1.3 & 0.2 & 0.4 & 2.0 & 0.4 & 1.1 & 0.3 & 0.8 & 1.8 & $\mathrm{BDL}$ & $\mathrm{BDL}$ & 6.9 & 7.0 \\
\hline DOB-5 & $10 / 31 / 96$ & Air/TEP & 0.2 & 4.0 & 3509.5 & 0.2 & 1.1 & 16.4 & 0.6 & 6.0 & 1.5 & 3.5 & 3.6 & $B D L$ & $B D L$ & 32.8 & 3513.7 \\
\hline DOB-5 & $11 / 15 / 96$ & Air/N2O & 0.5 & 15.3 & 14.2 & 0.5 & 1.3 & 3.2 & 1.3 & 0.5 & 3.0 & 3.4 & 8.0 & $\mathrm{BDL}$ & $\mathrm{BDL}$ & 21.3 & 29.9 \\
\hline DOB-5 & $11 / 27 / 96$ & Air/CH4 & 0.1 & 5.0 & 7.6 & 0.1 & 1.3 & $\overline{0.6}$ & 0.9 & 0.9 & 0.5 & 0.3 & 0.9 & $\overline{B D L}$ & $\overline{B D L}$ & 5.4 & 12.7 \\
\hline $\mathrm{DOB}-11$ & $9 / 20 / 96$ & Baseline & 4.2 & 8.0 & & 0.1 & 1.3 & 25.6 & 2.2 & 9.4 & 5.8 & 6.2 & 5.3 & & & 56.0 & 12.2 \\
\hline DOB-11 & $10 / 9 / 96$ & Air & 0.8 & 6.5 & & 0.6 & 2.1 & 0.9 & 0.2 & 10.7 & 12.5 & 2.0 & 4.0 & & & 33.0 & 7.3 \\
\hline $\mathrm{DOB}-11$ & $10 / 31 / 96$ & Air/TEP & 1.6 & 4.4 & & 0.5 & 2.3 & 0.6 & 0.8 & 0.8 & 2.6 & 2.1 & 2.4 & & & 12.0 & 6.0 \\
\hline$\overline{D O B}-11$ & $11 / 15 / 96$ & Air/N2O & 1.5 & 14.4 & & 0.3 & 1.2 & 4.8 & 1.2 & 4.4 & 3.7 & 1.9 & 13.2 & & & 30.6 & 15.9 \\
\hline DOB-11 & $11 / 27 / 96$ & Air/CH4 & 0.9 & 7.6 & & 0.1 & 1.4 & 31.2 & 0.1 & 13.9 & 1.0 & 0.0 & 0.0 & & & 47.7 & 8.6 \\
\hline DOB-13 & $9 / 20 / 96$ & Baseline & 618.2 & 9.3 & & 0.4 & 1.1 & 101.5 & 0.5 & 5.3 & 6.7 & \begin{tabular}{|l|l}
26.1 \\
\end{tabular} & 10.1 & & & 151.7 & 627.5 \\
\hline DOB-13 & $10 / 9 / 96$ & Air & 1.8 & 5.1 & & 0.2 & 1.6 & 7.4 & 1.3 & 4.9 & 2.2 & 5.0 & 5.7 & & & 28.2 & 6.8 \\
\hline$\overline{D O B}-13$ & $10 / 31 / 96$ & Air/TEP & 23.8 & 4.7 & & 0.1 & 0.7 & 1.5 & 0.3 & 1.5 & 3.8 & 1.2 & 3.4 & & & 12.6 & 28.6 \\
\hline DOB-13 & $11 / 15 / 96$ & Air $N 20$ & 352.1 & 5.5 & & 0.2 & 0.7 & 2.8 & 1.6 & 4.4 & 0.3 & 0.9 & 5.7 & & & 16.6 & 357.6 \\
\hline $\mathrm{DOB}-13$ & $11 / 27 / 96$ & Air $/ \mathrm{CH} 4$ & 353.0 & 0.2 & & 5.0 & 3.4 & 11.2 & 0.6 & 9.0 & 1.3 & 4.8 & 5.7 & & & 41.0 & 353.3 \\
\hline DOB-14 & $9 / 20 / 96$ & Baseline & 19.9 & 7.2 & & 15.8 & 0.7 & 180.7 & 0.8 & 17.2 & 1.8 & 0.7 & 1.5 & & & 219.2 & 27.1 \\
\hline DOB-14 & $10 / 9 / 96$ & Air & 182.1 & 4.6 & & 0.2 & 1.0 & 2.7 & 0.7 & 0.6 & 1.3 & 0.0 & 0.0 & & & 6.6 & 186.6 \\
\hline DOB-14 & $10 / 31 / 96$ & AirfTEP & 247.7 & 12.5 & & 0.1 & 0.5 & 0.4 & 1.1 & 0.9 & 0.6 & 0.0 & 0.0 & & & 3.6 & 260.3 \\
\hline$\overline{D O B}-14$ & $11 / 15 / 96$ & Air $/ \mathrm{N} 20$ & 320.2 & 4.5 & & 0.1 & 0.6 & 2.1 & 0.5 & 0.8 & 1.5 & 0.0 & 0.0 & & & 5.5 & 324.7 \\
\hline DOB-14 & $11 / 27 / 96$ & $\mathrm{Air} / \mathrm{CH} 4$ & 10.4 & 3.7 & & 0.1 & 0.4 & 12.3 & 1.4 & 12.2 & 1.7 & 0.0 & 0.0 & & & 28.1 & 14.1 \\
\hline
\end{tabular}


Substantial levels of petroleum hydrocarbons still remained at the end of the study, although total levels were reduced in DOB-4, 11,13, and 14. However, in view of the age of the DOSB, it is likely that the hydrocarbons are extremely weathered and may be relatively recalcitrant to microbial oxidation. Carbon limitation of potential VOC degraders might therefore still be a possibility.

Microbiological observations. Table 9 shows total bacterial numbers (Acridine Orange Direct Counts or AODC's), together with concentrations of aerobic bacteria culturable on a standard rich medium (1\% PTYG) and a mineral medium provided with diesel fumes as a carbon source (MPN/Diesel). Total bacterial numbers were moderate, ranging from 12200 to 75,400 cells per $\mathrm{ml}$ groundwater. This amount of variation is relatively minor and indicates few differences between wells or injection campaigns. This may reflect the presence of some petroleum hydrocarbons in upgradient wells, which are screened above the water table. The majority of the bacteria were nonculturable. It is not unusual for most bacteria in environmental samples to resist cultivation on standard media and this does not necessarily indicate that they are nonviable. In most wells, numbers of culturable bacteria were lower at the end of the study than at the beginning, likely reflecting the exhaustion of readily oxidizable substrates. A relatively large number of the culturable bacteria grew on minimal medium in the presence of petroleum hydrocarbons (diesel fumes). However, the identification of these bacteria as diesel degraders is questionable, as shown by the observation that control samples inoculated onto minimal medium (no carbon source) in the absence of diesel fumes developed similar numbers of colonies (Table 9). It is likely that sufficient carbon to support growth was present in the water samples used to inoculate the plates, and hence that the diesel fumes were not the only carbon source. 
D-Area Oil Seepage Basin

In Situ Bioremediation Optimization Test

WSRC-MS-96-0797, Rev. 0

Final Report

Jan. 24, 1997

Table 9. Microbiological enumerations in groundwater (cells/ml).

\begin{tabular}{|c|c|c|c|c|c|}
\multicolumn{1}{c}{ WEL } & CAMPAIGN & DATE & AODC'S & $1 \%$ PTYG & MPN/DIESEL \\
\hline DOB 2 & Baseline & $9 / 26 / 96$ & $1.00 E+05$ & 450 & 115 \\
\hline DOB 2 & Air & $10 / 9 / 96$ & $3.11 E+04$ & 165 & 40 \\
\hline DOB 2 & Air/TEP & $10 / 31 / 96$ & $7.43 E+04$ & 510 & 0 \\
\hline DOB 2 & Air/N2O & $11 / 15 / 96$ & $7.03 E+04$ & 45 & 30 \\
\hline DOB 2 & Air/CH4 & $11 / 27 / 96$ & $5.96 E+04$ & 105 & 45 \\
\hline DOB 3 & Baseline & $9 / 26 / 96$ & $5.29 E+05$ & 5700 & 1715 \\
\hline DOB 3 & Air & $10 / 9 / 96$ & $2.79 E+04$ & 1505 & 155 \\
\hline DOB 3 & Air/TEP & $10 / 31 / 96$ & $1.16 E+05$ & 670 & 50 \\
\hline DOB 3 & Air/N2O & $11 / 15 / 96$ & $1.25 E+05$ & 495 & 125 \\
\hline DOB 3 & Air/CH4 & $11 / 27 / 96$ & $6.54 E+04$ & 1120 & 920 \\
\hline DOB 4 & Baseline & $9 / 26 / 96$ & $1.22 E+04$ & 245 & 110 \\
\hline DOB 4 & Air & $10 / 9 / 96$ & $7.76 E+04$ & 255 & 45 \\
\hline DOB 4 & Air/TEP & $10 / 31 / 96$ & $1.27 E+04$ & 185 & 0 \\
\hline DOB 4 & Air/N2O & $11 / 15 / 96$ & $1.51 E+04$ & 35 & 0 \\
\hline DOB 4 & Air/CH4 & $11 / 27 / 96$ & $1.81 E+04$ & 65 & 10 \\
\hline DOB 5 & Baseline & $9 / 26 / 96$ & $9.64 E+04$ & 1450 & 1265 \\
\hline DOB 5 & Air & $10 / 9 / 96$ & $4.84 E+04$ & 2450 & 890 \\
\hline DOB 5 & Air/TEP & $10 / 31 / 96$ & $5.38 E+04$ & 2940 & 705 \\
\hline DOB 5 & Air/N2O & $11 / 15 / 96$ & $4.58 E+05$ & 2085 & 945 \\
\hline DOB 5 & Air/CH4 & $11 / 27 / 96$ & $1.57 E+05$ & 1555 & 590 \\
\hline DOB 11 & Baseline & $9 / 26 / 96$ & $4.69 E+05$ & 3225 & 730 \\
\hline DOB 11 & Air & $10 / 9 / 96$ & $3.11 E+05$ & 2300 & 340 \\
\hline DOB 11 & Air/TEP & $10 / 31 / 96$ & $2.96 E+05$ & 2905 & 10 \\
\hline DOB 11 & Air/N2O & $11 / 15 / 96$ & $3.98 E+05$ & 670 & 85 \\
\hline DOB 11 & Air/CH4 & $11 / 27 / 96$ & $7.54 E+05$ & 535 & 265 \\
\hline DOB 13 & Baseline & $9 / 26 / 96$ & $1.58 E+05$ & 2035 & 1800 \\
\hline DOB 13 & Air & $10 / 9 / 96$ & $1.84 E+04$ & 1415 & 355 \\
\hline DOB 13 & Air/TEP & $10 / 31 / 96$ & $1.26 E+05$ & 1130 & 0 \\
\hline DOB 13 & Air/N2O & $11 / 15 / 96$ & $4.79 E+04$ & 1730 & 1325 \\
\hline DOB 13 & Air/CH4 & $11 / 27 / 96$ & $1.82 E+05$ & 230 & 45 \\
\hline DOB 14 & Baseline & $9 / 26 / 96$ & $1.62 E+05$ & 6100 & 4850 \\
\hline DOB 14 & Air & $10 / 9 / 96$ & $2.00 E+05$ & 560 & 1345 \\
\hline DOB 14 & Air/TEP & $10 / 31 / 96$ & $5.60 E+04$ & 935 & 35 \\
\hline DOB 14 & Air/N2O & $11 / 15 / 96$ & $9.31 E+04$ & 565 & 320 \\
\hline DOB 14 & Air/CH4 & $11 / 27 / 96$ & $7.35 E+04$ & 920 & 950 \\
\hline
\end{tabular}

CONTROL SAMPLES

\begin{tabular}{|c|c|c|c|}
\multicolumn{1}{c}{ WELL } & DATE & MPN/DIESEL & MPN/no C \\
\hline DOB 5B & $11 / 15 / 96$ & 945 & 1335 \\
\hline DOB 11B & $11 / 27 / 96$ & 265 & 230 \\
\hline DOB 13B & $11 / 27 / 96$ & 45 & 125 \\
\hline DOB 14B & $11 / 27 / 96$ & 950 & 1545 \\
\hline
\end{tabular}




\section{Conclusions}

1. Oxygen, carbon dioxide, and methane levels in soil gas, as well as a decline in PCE levels, indicate substantial levels of baseline or natural microbial activity.

2. Groundwater monitoring also indicates that a significant amount of natural contaminant biodegradation occurred prior to air injection. This is evidenced by elevated chloride and sulfate levels (resulting from degradation of chlorinated compounds and petroleum hydrocarbons, respectively), low oxygen levels, and an observed decline in volatile organic content.

3. Effective aeration was consistently achieved only at the four corner piezometers. This impaired aerobic degradation of chlorinated VOC's in the center and allowed continued anaerobic degradation (which would eventually lead to the production of vinyl chloride), as shown by the presence of intermediates in the anaerobic degradative pathway.

4. Air injection accelerated the degradation of PCE in the soil of the basin. A mean PCE degradation rate of $1.7 \mathrm{ppb} /$ day was calculated for areas having low to medium PCE levels (the major portion of the site). TCE degradation was also stimulated in areas receiving adequate aeration.

5. Based on observed PCE degradation rates, minimum cleanup time is estimated at 124 days (approximately 4 months). This rate is dependent on the achievement of adequate air flow throughout the site.

6. Air injection had little or no effect on groundwater water quality parameters. This is attributed to the previous degradation of contaminants (carbon limitation), as shown by the absence of measurable VOC's .

7. Addition of TEP (triethylphosphate) resulted in a decline in oxygen levels in soil gas, and may have stimulated respiration rates and PCE degradation in portions of the site with the highest chlorinated solvent levels.

8. Aerated portions of the basin with lower initial contaminant levels showed indications of developing carbon limitation during the study. This was shown by a failure of TEP injection to stimulate respiration at these piezometers and a decline in respiration rates during subsequent injection campaigns. 
9. Results of in situ respirometry indicated mean oxygen consumption levels of $0.28 \% \mathrm{O}_{2} / \mathrm{h}$ after injection of air or air plus TEP. This results in estimated mean petroleum hydrocarbon degradation rates of about $4.2 \mathrm{mg} / \mathrm{kg}$ soil/day, a fairly high value for soils. By the end of the study, mean respiration rate was $0.12 \% \mathrm{O}_{2} / \mathrm{h}$, corresponding to 1.8 $\mathrm{mg} / \mathrm{kg}$ soil/day.

10. Surface emissions of VOC's were negligible, even during air injection. This indicates that VOC degradation resulted primarily from biological activity rather than air stripping.

11. The induction of aerobic conditions may have reduced the mobility of metal contaminants leaching from the DOSB.

\section{Recommendations}

1. Additional aeration of the site is recommended in order to allow continued contaminant degradation.

2. Air flow to the central areas of the site is extremely restricted. It is recommended that additional injection wells be installed in regions of inadequate air flow.

3. In view of evidence suggesting that phosphorus is limiting at times in portions of the site, continued use of TEP (as needed) is suggested.

4. If time is not a primary driver, and since groundwater contamination has already decreased to below detection limits, intrinsic bioremediation could be an appropriate strategy for this site.

5. Methane injection will be necessary if PAH's, TCE, and PCE persist in the soil after a reasonable period of bioventing.

6. Recommended air flow rate is approximately $100 \mathrm{scfm}$. This is estimated to allow an minimum average 15-foot radius of influence for each of the two horizontal wells (as the system is currently configured) and an minimum affected soil volume of $5.4 \times 10^{5} \mathrm{ft}^{3}$. 


\section{References}

Balkwill, D. L., 1989. Numbers, diversity, and morphological characteristics of aerobic, chemoheterotrophic bacteria in deep subsurface sediments from a site in South Carolina. Geomicrobiol. J. 7:33-52.

EPA (U.S. Environmental Protection Agency), 1995. Bioventing Principles and Practice, EPA/540/R-95/534a, Washington, DC.

Hazen, T.C. 1996. Sanitary Landfill in situ bioremediation optimization test final report. (DOE - NITS).Westinghouse Savannah River Company, Aiken, SC. WSRC-TR-96-0065.

Hazen, T. C., K.H. Lombard, B. B. Looney, M. V. Enzien, J. M. Dougherty, C. B. Fliermans, J. Wear, and C. A. Eddy-Dilek, 1994. Summary of in situ bioremediation demonstration (methane biostimulation) via horizontal wells at the Savannah River Site Integrated Demonstration Project. In: G. W. Gee and N. R. Wing (eds.), Proceedings of the 33d Hanford Symposium on Health and the Environment: In-Situ Remediation: Scientific Basis for Current and Future Technologies. Battelle Press, Columbus, Ohio.

WSRC (Westinghouse Savannah River Company), 1993. Preliminary Technology Report for the In Situ Bioremediation Demonstration (Methane Biostimulation) of the Savannah River Integrated Demonstration Project, DOE/OTD (U). Prepared for DOE, WSRC-TR93-670.

WSRC (Westinghouse Savannah River Company), 1994. Phase II RCRA Facility Investigation/Remedial Investigation Work Plan. Prepared for DOE, WSRC-RP- 941175, Rev. 0. October, 1994. 
D-Area Oil Seepage Basin

In Situ Bioremediation Optimization Test

Final Report
WSRC-MS-96-0797, Rev. 0

Jan. 24, 1997

Appendix 1. Soil Gas Observations

\begin{tabular}{|c|c|c|c|c|c|c|c|c|c|}
\hline Piezometer & Status & Campaign & Date & Time & $\% \mathrm{CH}_{4}$ & $\% \mathrm{CO}_{2}$ & $\% \mathrm{O}_{2}$ & $\begin{array}{c}\text { Pressure, } \\
\text { " } \mathrm{H} 2 \mathrm{O}\end{array}$ & $\mathrm{O} 2 / \mathrm{CO} 2$ \\
\hline 1 & OFF & Baseline & $7 / 8 / 96$ & - & 2.1 & 25.1 & 4 & - & 0.16 \\
\hline 1 & OFF & Baseline & $7 / 18 / 96$ & - & 3.1 & 32.1 & 0.1 & 0 & 0.00 \\
\hline 1 & OFF & Baseline & $7 / 23 / 96$ & - & 3.2 & 33.3 & 0.1 & 0 & 0.00 \\
\hline 1 & OFF & Baseline & $7 / 30 / 96$ & - & 3.3 & 33.7 & 0.1 & 0 & 0.00 \\
\hline 1 & OFF & Baseline & $8 / 6 / 96$ & - & 3.2 & 33.5 & 0.1 & 0 & 0.00 \\
\hline 1 & OFF & Baseline & $8 / 16 / 96$ & - & 3.8 & 30.5 & 0.7 & - & 0.02 \\
\hline 1 & OFF & Baseline & $8 / 21 / 96$ & - & 2.6 & 31.3 & 0 & 0 & 0.00 \\
\hline 1 & OFF & Baseline & $9 / 19 / 96$ & - & 0.8 & 22.8 & 3.8 & - & 0.17 \\
\hline 1 & OFF & Baseline & $9 / 21 / 96$ & - & 0.6 & 18.4 & 6.7 & 0 & 0.36 \\
\hline 1 & ON & Air & $10 / 6 / 96$ & 935 & 0 & 1.1 & 18.3 & 0.9 & 16.64 \\
\hline 1 & ON & Air & $10 / 8 / 96$ & 1148 & 0 & 1.1 & 18.3 & 1.6 & 16.64 \\
\hline 1 & ON & Air & $10 / 9 / 96$ & 1145 & 0 & 1.1 & 18.4 & 1.5 & 16.73 \\
\hline 1 & ON & Air & $10 / 10 / 96$ & 1237 & - & 0.6 & 18.7 & - & 31.17 \\
\hline 1 & ON & Air + TEP & $10 / 24 / 96$ & 938 & 0 & 1.3 & 18.7 & 0.9 & 14.38 \\
\hline 1 & ON & Air + TEP & $10 / 30 / 96$ & 944 & 0 & 1.3 & 18.6 & 0.8 & 14.31 \\
\hline 1 & ON & Air + TEP & $10 / 31 / 96$ & 1107 & 0 & 1 & 18.4 & - & 18.40 \\
\hline 1 & ON & Air + TEP & $10 / 31 / 96$ & 1330 & 0 & 1 & 18.2 & - & 18.20 \\
\hline 1 & ON & Air + N2O & $11 / 12 / 96$ & 927 & 0 & 1 & 19.5 & - & 19.50 \\
\hline 1 & ON & Air + N2O & $11 / 15 / 96$ & 1140 & 0 & 1 & 19 & - & 19.00 \\
\hline 1 & ON & $\mathrm{Air}+\mathrm{CH} 4$ & $11 / 24 / 96$ & 1155 & 0 & 1 & 19.2 & 0.7 & 19.20 \\
\hline 1 & ON & $\mathrm{Air}+\mathrm{CH}_{4}$ & $11 / 24 / 96$ & 1455 & 0 & 0.8 & 19.1 & - & 23.88 \\
\hline 1 & ON & $\mathrm{Air}+\mathrm{CH} 4$ & $11 / 27 / 96$ & 1217 & 0.8 & 0.9 & 18.6 & - & 20.67 \\
\hline 2 & OFF & Baseline & $7 / 8 / 96$ & - & 0 & 10.7 & 10.2 & - & 0.95 \\
\hline 2 & OFF & Baseline & $7 / 18 / 96$ & - & 0.3 & 22.3 & 0.4 & 0 & 0.02 \\
\hline 2 & OFF & Baseline & $7 / 23 / 96$ & - & 0 & 22.2 & 0.5 & 0.1 & 0.02 \\
\hline 2 & OFF & Baseline & $7 / 30 / 96$ & - & 5.3 & 4.1 & 0.7 & 0.2 & 0.17 \\
\hline 2 & OFF & Baseline & $8 / 6 / 96$ & - & 0.1 & 23 & 0.2 & 0 & 0.01 \\
\hline 2 & OFF & Baseline & $8 / 16 / 96$ & - & 9.5 & 12.6 & 0.6 & - & 0.05 \\
\hline 2 & OFF & Baseline & $8 / 21 / 96$ & - & 0 & 22 & 0 & 0 & 0.00 \\
\hline 2 & OFF & Baseline & $9 / 19 / 96$ & - & 0 & 12.4 & 7.1 & - & 0.57 \\
\hline 2 & OFF & Baseline & $9 / 21 / 96$ & - & 0 & 10.6 & 9.2 & 0 & 0.87 \\
\hline 2 & $\mathrm{ON}$ & Air & $10 / 6 / 96$ & 935 & 0 & 10.6 & 9.1 & 0 & 0.86 \\
\hline 2 & ON & Air & $10 / 8 / 96$ & 1148 & 0 & 9.6 & 10 & 0.1 & 1.04 \\
\hline 2 & ON & Air & $10 / 9 / 96$ & 1145 & 0 & 12.2 & 6.9 & 0 & 0.57 \\
\hline 2 & ON & Air & $10 / 10 / 96$ & 1237 & - & 11.2 & 6.6 & - & 0.59 \\
\hline 2 & ON & Air + TEP & $10 / 24 / 96$ & 923 & 0.1 & 17.4 & 0.7 & 0 & 0.04 \\
\hline 2 & ON & $\mathrm{Air}$ + TEP & $10 / 30 / 96$ & 1006 & 0 & 6.3 & 6.6 & 0 & 1.05 \\
\hline 2 & ON & Air + TEP & $10 / 31 / 96$ & 1052 & 0 & 15.9 & 1.5 & - & 0.09 \\
\hline 2 & ON & Air + TEP & $10 / 31 / 96$ & 1318 & 0 & 16.1 & 1.3 & - & 0.08 \\
\hline 2 & ON & $\mathrm{Air}+\mathrm{N} 2 \mathrm{O}$ & $11 / 12 / 96$ & 912 & 0 & 12.9 & 4.3 & - & 0.33 \\
\hline 2 & ON & Air + N2O & $11 / 15 / 96$ & 1132 & 0 & 12.4 & 4.6 & - & 0.37 \\
\hline 2 & ON & $\mathrm{Air}+\mathrm{CH}_{4}$ & $11 / 24 / 96$ & 1146 & 0 & 12.2 & 3.5 & 0 & 0.29 \\
\hline 2 & ON & $\mathrm{Air}+\mathrm{CH} 4$ & $11 / 24 / 96$ & 1445 & 0 & 12.2 & 3.8 & - & 0.31 \\
\hline 2 & ON & $\mathrm{Air}+\mathrm{CH}_{4}$ & $11 / 27 / 96$ & 1159 & 0 & 11.7 & 4.6 & - & 0.39 \\
\hline
\end{tabular}


D-Area Oil Seepage Basin

In Situ Bioremediation Optimization Test

Final Report
WSRC-MS-96-0797, Rev. 0

Jan. 24, 1997

Appendix 1 (cont'd)

\begin{tabular}{|c|c|c|c|c|c|c|c|c|c|}
\hline Piezometer & Status & Campaign & Date & Time & $\% \mathrm{CH}_{4}$ & $\% \mathrm{CO}_{2}$ & $\% \mathrm{O}_{2}$ & $\begin{array}{c}\text { Pressure, } \\
" \mathrm{H} 2 \mathrm{O}\end{array}$ & $\mathrm{O} 2 / \mathrm{CO}_{2}$ \\
\hline 3 & OFF & Baseline & $7 / 8 / 96$ & - & 0.2 & 14.5 & 7 & - & 0.48 \\
\hline 3 & OFF & Baseline & $7 / 18 / 96$ & - & 2.7 & 13.4 & 0 & 0 & 0.00 \\
\hline 3 & OFF & Baseline & $7 / 23 / 96$ & - & 0.4 & 24.1 & 0 & 0 & 0.00 \\
\hline 3 & OFF & Baseline & $7 / 30 / 96$ & - & 0.2 & 23.8 & 0 & 0.1 & 0.00 \\
\hline 3 & OFF & Baseline & $8 / 6 / 96$ & - & 0 & 23.3 & 0 & 0 & 0.00 \\
\hline 3 & OFF & Baseline & $8 / 16 / 96$ & - & 0.1 & 21.9 & 0 & - & 0.00 \\
\hline 3 & OFF & Baseline & $8 / 21 / 96$ & - & 0 & 22.4 & 0 & 0 & 0.00 \\
\hline 3 & OFF & Baseline & $9 / 19 / 96$ & - & 0 & 18 & 2.3 & - & 0.13 \\
\hline 3 & OFF & Baseline & $9 / 21 / 96$ & - & 0 & 14.6 & 5.5 & 0 & 0.38 \\
\hline 3 & ON & Air & $10 / 6 / 96$ & 935 & 0 & 1.8 & 17.7 & 0.5 & 9.83 \\
\hline 3 & ON & Air & $10 / 8 / 96$ & 1148 & - & 1 & 18.8 & 1 & 18.80 \\
\hline 3 & $\mathrm{ON}$ & Air & $10 / 9 / 96$ & 1145 & - & 1.1 & 18.7 & 0.9 & 17.00 \\
\hline 3 & ON & Air & $10 / 10 / 96$ & 1237 & 0 & 1.1 & 18.9 & - & 17.18 \\
\hline 3 & ON & Air + TEP & $10 / 24 / 96$ & 909 & 0 & 1.2 & 19.1 & 0.4 & 15.92 \\
\hline 3 & ON & Air + TEP & $10 / 30 / 96$ & 1022 & 0 & 1 & 19 & 0.4 & 19.00 \\
\hline 3 & ON & Air + TEP & $10 / 31 / 96$ & 1031 & 0 & 0.9 & 19.2 & - & 21.33 \\
\hline 3 & $O N$ & Air + TEP & $10 / 31 / 96$ & 1305 & 0 & 0.9 & 19.1 & - & 21.22 \\
\hline 3 & ON & Air + N2O & $11 / 12 / 96$ & 856 & 0 & 0.4 & 20.3 & - & 50.75 \\
\hline 3 & ON & $\mathrm{Air}+\mathrm{N} 2 \mathrm{O}$ & $11 / 15 / 96$ & 1117 & 0 & 0.5 & 19.7 & - & 39.40 \\
\hline 3 & ON & $\mathrm{Air}+\mathrm{CH} 4$ & $11 / 24 / 96$ & 1137 & 0 & 0.3 & 20.2 & 0.5 & 67.33 \\
\hline 3 & ON & $\mathrm{Air}+\mathrm{CH} 4$ & $11 / 24 / 96$ & 1436 & 0.1 & 0.3 & 20.1 & - & 67.00 \\
\hline 3 & ON & $\mathrm{Air}+\mathrm{CH} 4$ & $11 / 27 / 96$ & 1140 & 0.7 & 0.5 & 19.4 & - & 38.80 \\
\hline 4 & OFF & Baseline & $7 / 8 / 96$ & - & 0.5 & 17.2 & 6.6 & - & 0.38 \\
\hline 4 & OFF & Baseline & $7 / 18 / 96$ & - & 0.5 & 19.9 & 5 & 0 & 0.25 \\
\hline 4 & OFF & Baseline & $7 / 23 / 96$ & - & 0.5 & 21.9 & 4.4 & 0 & 0.20 \\
\hline 4 & OFF & Baseline & $7 / 30 / 96$ & - & 0.4 & 19.6 & 5.1 & 0 & 0.26 \\
\hline 4 & OFF & Baseline & $8 / 6 / 96$ & - & 0.3 & 19.7 & 5.3 & 0 & 0.27 \\
\hline 4 & OFF & Baseline & $8 / 16 / 96$ & - & 0.4 & 19.6 & 4.9 & - & 0.25 \\
\hline 4 & OFF & Baseline & $8 / 21 / 96$ & - & 0.1 & 20.9 & 4 & 0 & 0.19 \\
\hline 4 & OFF & Baseline & $9 / 19 / 96$ & - & 0 & 12.6 & 8.8 & - & 0.70 \\
\hline 4 & OFF & Baseline & $9 / 21 / 96$ & - & 0 & 9.2 & 11.6 & 0 & 1.26 \\
\hline 4 & ON & Air & $10 / 6 / 96$ & 935 & 0 & 6.1 & 10.6 & 0.4 & 1.74 \\
\hline 4 & ON & Air & $10 / 8 / 96$ & 1148 & 0 & 4.9 & 12.4 & 1 & 2.53 \\
\hline 4 & ON & Air & $10 / 9 / 96$ & 1145 & 0 & 4.5 & 12.7 & 1 & 2.82 \\
\hline 4 & ON & Air & $10 / 10 / 96$ & 1237 & - & 3.5 & 13.2 & - & 3.77 \\
\hline 4 & $\mathrm{ON}$ & Air + TEP & $10 / 24 / 96$ & 943 & 0 & 11.6 & 4.2 & 0.5 & 0.36 \\
\hline 4 & $\mathrm{ON}$ & Air + TEP & $10 / 30 / 96$ & 956 & 0 & 8.2 & 8.2 & 0.4 & 1.00 \\
\hline 4 & ON & Air + TEP & $10 / 31 / 96$ & 1110 & 0 & 9.4 & 6.2 & - & 0.66 \\
\hline 4 & ON & Air + TEP & $10 / 31 / 96$ & 1334 & 0 & 9.2 & 7 & - & 0.76 \\
\hline 4 & ON & Air + N2O & $11 / 12 / 96$ & 930 & 0 & 7.1 & 9.8 & - & 1.38 \\
\hline 4 & ON & Air + N2O & $11 / 15 / 96$ & 1155 & 0 & 6.9 & 10.5 & - & 1.52 \\
\hline 4 & ON & $\mathrm{Air}+\mathrm{CH}_{4}$ & $11 / 24 / 96$ & 1156 & 0 & 6.8 & 10.1 & 0.4 & 1.49 \\
\hline 4 & ON & $\mathrm{Air}+\mathrm{CH} 4$ & $11 / 24 / 96$ & 1457 & 0 & 6.9 & 10.4 & - & 1.51 \\
\hline 4 & ON & $\mathrm{Air}+\mathrm{CH} 4$ & $11 / 27 / 96$ & 1222 & 0 & 7 & 10.5 & - & 1.50 \\
\hline
\end{tabular}


D-Area Oil Seepage Basin

In Situ Bioremediation Optimization Test

Final Report
WSRC-MS-96-0797, Rev. 0

Jan. 24, 1997

Appendix 1 (cont'd)

\begin{tabular}{|c|c|c|c|c|c|c|c|c|c|}
\hline Piezomete & Status & Campaign & Date & Time & $\% \mathrm{CH}_{4}$ & $\% \mathrm{CO}_{2}$ & $\% \mathrm{O}_{2}$ & $\begin{array}{c}\text { Pressure, } \\
\text { "H2O }\end{array}$ & $\mathrm{O} 2 / \mathrm{CO} 2$ \\
\hline 5 & OFF & Baseline & $7 / 8 / 96$ & - & 0.3 & 10.6 & 10.5 & - & 0.99 \\
\hline 5 & OFF & Baseline & $7 / 18 / 96$ & - & 0.6 & 21.6 & 0.4 & 0 & 0.02 \\
\hline 5 & OFF & Baseline & $7 / 23 / 96$ & - & 6.4 & 11 & 0.5 & 0.2 & 0.05 \\
\hline 5 & OFF & Baseline & $8 / 1 / 96$ & - & 0.3 & 22.2 & 0.4 & 0 & 0.02 \\
\hline 5 & OFF & Baseline & $8 / 6 / 96$ & - & 0.4 & 21.9 & 0.3 & 0 & 0.01 \\
\hline 5 & OFF & Baseline & $8 / 16 / 96$ & - & 4.9 & 9.5 & 0.5 & - & 0.05 \\
\hline 5 & OFF & Baseline & $8 / 21 / 96$ & - & 0.1 & 20.9 & 0.4 & 0 & 0.02 \\
\hline 5 & OFF & Baseline & 9/19/96 & - & 0 & 12.7 & 6.6 & - & 0.52 \\
\hline 5 & OFF & Baseline & $9 / 21 / 96$ & - & 0 & 11 & 8.4 & 0 & 0.76 \\
\hline 5 & ON & Air & $10 / 6 / 96$ & 935 & 0 & 9.6 & 9.5 & 0 & 0.99 \\
\hline 5 & ON & Air & $10 / 8 / 96$ & 1148 & 0 & 9.7 & 9 & 0.1 & 0.93 \\
\hline 5 & ON & Air & $10 / 9 / 96$ & 1145 & 0 & 9.3 & 9.1 & 0 & 0.98 \\
\hline 5 & ON & Air & $10 / 10 / 96$ & 1237 & - & 10.6 & 4.2 & $=$ & 0.40 \\
\hline 5 & ON & Air + TEP & $10 / 24 / 96$ & 927 & 0 & 15.2 & 2.2 & 0 & 0.14 \\
\hline 5 & ON & Air + TEP & $10 / 30 / 96$ & 1010 & 0 & 9.7 & 3.7 & 0 & 0.38 \\
\hline 5 & ON & Air + TEP & $10 / 31 / 96$ & 1056 & 0 & 14.7 & 2.1 & - & 0.14 \\
\hline 5 & ON & Air + TEP & $10 / 31 / 96$ & 1321 & 0 & 14.2 & 2.5 & - & 0.18 \\
\hline 5 & ON & Air $+\mathrm{N} 2 \mathrm{O}$ & $11 / 12 / 96$ & 915 & 0 & 11.9 & 4.6 & - & 0.39 \\
\hline 5 & ON & $\mathrm{Air}+\mathrm{N} 2 \mathrm{O}$ & $11 / 15 / 96$ & 1136 & 0 & 12.1 & 4.7 & - & 0.39 \\
\hline 5 & ON & $\mathrm{Air}+\mathrm{CH}_{4}$ & $11 / 24 / 96$ & 1149 & 0 & 12.1 & 3.5 & 0 & 0.29 \\
\hline 5 & ON & $\mathrm{Air}+\mathrm{CH} 4$ & $11 / 24 / 96$ & 1448 & 0 & 12 & $\overline{4.1}$ & - & 0.34 \\
\hline 5 & ON & $\mathrm{Air}+\mathrm{CH} 4$ & $11 / 27 / 96$ & 1204 & 0 & 9.9 & 4.6 & - & 0.46 \\
\hline 6 & OFF & Baseline & $7 / 8 / 96$ & - & 0 & 13.5 & 8.3 & - & 0.61 \\
\hline 6 & OFF & Baseline & $7 / 18 / 96$ & - & 0.1 & 18.1 & 5.2 & 0.1 & 0.29 \\
\hline 6 & OFF & Baseline & $7 / 23 / 96$ & - & 0.2 & 18.8 & 5.2 & 0 & 0.28 \\
\hline 6 & OFF & Baseline & $7 / 30 / 96$ & - & 4 & 10.2 & 5.2 & 0 & 0.51 \\
\hline 6 & OFF & Baseline & $8 / 6 / 96$ & - & 0 & 18.3 & 5.2 & 0 & 0.28 \\
\hline 6 & OFF & Baseline & $8 / 16 / 96$ & - & 0 & 11.4 & 5.9 & - & 0.52 \\
\hline 6 & OFF & Baseline & $8 / 21 / 96$ & - & 0 & 17.2 & 5.6 & 0 & 0.33 \\
\hline 6 & OFF & Baseline & $9 / 19 / 96$ & - & 0 & 11 & 9.9 & - & 0.90 \\
\hline 6 & OFF & Baseline & $9 / 21 / 96$ & - & 0 & 10.8 & 10.1 & 0 & 0.94 \\
\hline 6 & ON & Air & $10 / 6 / 96$ & 935 & 0 & 9.9 & 6.5 & 0.4 & 0.66 \\
\hline 6 & $\mathrm{ON}$ & Air & $10 / 8 / 96$ & 1148 & - & 8.2 & 10.1 & 1 & 1.23 \\
\hline 6 & ON & Air & $10 / 9 / 96$ & 1145 & - & 4.8 & 13.2 & 0.9 & 2.75 \\
\hline 6 & ON & Air & $10 / 10 / 96$ & 1237 & 0 & 7.4 & 9.8 &.- & 1.32 \\
\hline 6 & ON & Air + TEP & $10 / 24 / 96$ & 913 & 0 & 6 & 11.8 & 0.3 & 1.97 \\
\hline 6 & ON & Air + TEP & $10 / 30 / 96$ & 1028 & 0 & 5.7 & 13.4 & 0.2 & 2.35 \\
\hline 6 & ON & Air + TEP & $10 / 31 / 96$ & 1037 & 0 & 4 & 14.5 & - & 3.63 \\
\hline 6 & ON & Air + TEP & $10 / 31 / 96$ & 1309 & 0 & 4.1 & 14.1 & - & 3.44 \\
\hline 6 & ON & $\mathrm{Air}+\mathrm{N} 2 \mathrm{O}$ & $11 / 12 / 96$ & 904 & 0 & 3.7 & 16 & - & 4.32 \\
\hline 6 & ON & $\mathrm{Air}+\mathrm{N} 2 \mathrm{O}$ & $11 / 15 / 96$ & 1122 & 0 & 3.5 & 16 & - & 4.57 \\
\hline 6 & ON & $\mathrm{Air}+\mathrm{CH} 4$ & $11 / 24 / 96$ & 1139 & 0.3 & 3.8 & 15.2 & 0.2 & 4.00 \\
\hline 6 & ON & $\mathrm{Air}+\mathrm{CH} 4$ & $11 / 24 / 96$ & 1438 & 0.1 & 3.6 & 15.5 & - & 4.31 \\
\hline 6 & ON & $\mathrm{Air}+\mathrm{CH} 4$ & $11 / 27 / 96$ & 1148 & 0 & 3.7 & 15.6 & - & 4.22 \\
\hline
\end{tabular}


D-Area Oil Seepage Basin

WSRC-MS-96-0797, Rev. 0

In Situ Bioremediation Optimization Test

Jan. 24, 1997

Final Report

Appendix 1 (cont'd)

\begin{tabular}{|c|c|c|c|c|c|c|c|c|c|}
\hline Piezometer & Status & Campaign & Date & Time & $\% \mathrm{CH}_{4}$ & $\% \mathrm{CO}_{2}$ & $\% \mathrm{O}_{2}$ & $\begin{array}{c}\text { Pressure, } \\
\text { " } 12 \mathrm{O}\end{array}$ & $\mathrm{O} 2 / \mathrm{CO} 2$ \\
\hline 7 & OFF & Baseline & $7 / 8 / 96$ & - & 0 & 14 & 5 & - & 0.36 \\
\hline 7 & OFF & Baseline & $7 / 18 / 96$ & - & 0 & 16.2 & 3.6 & 0 & 0.22 \\
\hline 7 & OFF & Baseline & $7 / 23 / 96$ & - & 0 & 15.8 & 4.8 & 0 & 0.30 \\
\hline 7 & OFF & Baseline & $7 / 30 / 96$ & - & 0 & 15.4 & 4.7 & 0 & 0.31 \\
\hline 7 & OFF & Baseline & $8 / 6 / 96$ & - & 0 & 15.1 & 5 & 0 & 0.33 \\
\hline 7 & OFF & Baseline & $8 / 16 / 96$ & - & 0 & 15.3 & 4.7 & - & 0.31 \\
\hline 7 & OFF & Baseline & $8 / 21 / 96$ & - & 0 & 15.8 & 4.2 & 0 & 0.27 \\
\hline 7 & OFF & Baseline & $9 / 19 / 96$ & - & 0 & 9.2 & 9.6 & - & 1.04 \\
\hline 7 & OFF & Baseline & $9 / 21 / 96$ & - & 0 & 10 & 8.8 & 0 & 0.88 \\
\hline 7 & ON & Air & $10 / 6 / 96$ & 935 & 0 & 1.1 & 19 & 0.2 & 17.27 \\
\hline 7 & ON & Air & $10 / 8 / 96$ & 1148 & 0 & 0.9 & 18.6 & 0.6 & 20.67 \\
\hline 7 & ON & Air & $10 / 9 / 96$ & 1145 & 0 & 1.1 & 18.5 & 0.5 & 16.82 \\
\hline 7 & ON & Air & $10 / 10 / 96$ & 1237 & - & 0.6 & 19 & - & 31.67 \\
\hline 7 & $\mathrm{ON}$ & Air + TEP & $10 / 24 / 96$ & 946 & 0 & 1.6 & 18.7 & 0.2 & 11.69 \\
\hline 7 & ON & Air + TEP & $10 / 30 / 96$ & 955 & 0 & 1.5 & 18.6 & 0.2 & 12.40 \\
\hline 7 & ON & Air + TEP & $10 / 31 / 96$ & 1115 & 0 & 1.1 & 18.7 & - & 17.00 \\
\hline 7 & ON & Air + TEP & $10 / 31 / 96$ & 1338 & 0 & 1.3 & 18.4 & - & 14.15 \\
\hline 7 & ON & Air + N2O & $11 / 12 / 96$ & 934 & 0 & 1.3 & 19.1 & - & 14.69 \\
\hline 7 & ON & $\mathrm{Air}+\mathrm{N} 2 \mathrm{O}$ & $11 / 15 / 96$ & 1200 & 0 & 1.2 & 19 & - & 15.83 \\
\hline 7 & ON & $\mathrm{Air}+\mathrm{CH} 4$ & $11 / 24 / 96$ & 1159 & 0 & 1.2 & 19.1 & 0.2 & 15.92 \\
\hline 7 & ON & $\mathrm{Air}+\mathrm{CH} 4$ & $11 / 24 / 96$ & 1149 & 0 & 0.9 & 19.1 & - & 21.22 \\
\hline 7 & ON & Air $+\mathrm{CH}_{4}$ & $11 / 27 / 96$ & 1225 & 0.5 & 1 & 18.8 & - & 18.80 \\
\hline 8 & OFF & Baseline & $7 / 8 / 96$ & - & 0 & 8.8 & 9.3 & - & 1.06 \\
\hline 8 & OFF & Baseline & $7 / 18 / 96$ & - & 0 & 16.9 & 0 & 0 & 0.00 \\
\hline 8 & OFF & Baseline & $7 / 23 / 96$ & - & 0 & 17.5 & 0 & 0 & 0.00 \\
\hline 8 & OFF & Baseline & $8 / 1 / 96$ & - & 0 & 18.3 & 0 & 0 & 0.00 \\
\hline 8 & OFF & Baseline & $8 / 6 / 96$ & - & 0 & 17.7 & 0 & 0 & 0.00 \\
\hline 8 & OFF & Baseline & $8 / 16 / 96$ & - & 11.2 & 10.6 & 0.1 & - & 0.01 \\
\hline 8 & OFF & Baseline & $8 / 21 / 96$ & - & 0 & 16.8 & 0.3 & 0 & 0.02 \\
\hline 8 & OFF & Baseline & $9 / 19 / 96$ & - & 0 & 11.8 & 5.7 & - & 0.48 \\
\hline 8 & OFF & Baseline & $9 / 21 / 96$ & - & 0 & 9 & 9.3 & 0 & 1.03 \\
\hline 8 & ON & Air & $10 / 6 / 96$ & 935 & 0 & 7.8 & 10.5 & 0 & 1.35 \\
\hline 8 & ON & Air & $10 / 8 / 96$ & 1148 & 0 & 6.9 & 11.8 & 0.2 & 1.71 \\
\hline 8 & ON & Air & $10 / 9 / 96$ & 1145 & 0 & 4.7 & 13.9 & 0.9 & 2.96 \\
\hline 8 & ON & Air & $10 / 10 / 96$ & 1237 & - & 4.9 & 11.3 & - & 2.31 \\
\hline 8 & ON & Air + TEP & $10 / 24 / 96$ & 930 & 0 & 13.6 & 0.8 & 0 & 0.06 \\
\hline 8 & ON & Air + TEP & $10 / 30 / 96$ & 1015 & 0 & 7.2 & 11.7 & 0 & 1.63 \\
\hline 8 & ON & Air + TEP & $10 / 31 / 96$ & 1100 & 0 & 12.3 & 2.7 & - & 0.22 \\
\hline 8 & $\mathrm{ON}$ & Air + TEP & $10 / 31 / 96$ & 1325 & 0 & 13.2 & 1.9 & - & 0.14 \\
\hline 8 & ON & Air + N2O & $11 / 12 / 96$ & 920 & 0 & 9.7 & 9.4 & - & 0.97 \\
\hline 8 & ON & $\mathrm{Air}+\mathrm{N} 2 \mathrm{O}$ & $11 / 15 / 96$ & 1143 & 0 & 7.3 & 11.1 & - & 1.52 \\
\hline 8 & ON & $\mathrm{Air}+\mathrm{CH} 4$ & $11 / 24 / 96$ & 1150 & 0 & 8.1 & 10.2 & 0 & 1.26 \\
\hline 8 & ON & Air $+\mathrm{CH} 4$ & $11 / 24 / 96$ & 1450 & 0 & 8.3 & 10.4 & - & 1.25 \\
\hline 8 & ON & $\mathrm{Air}+\mathrm{CH} 4$ & $11 / 27 / 96$ & 1213 & 0 & 6.6 & 11.7 & - & 1.77 \\
\hline
\end{tabular}


D-Area Oil Seepage Basin

In Situ Bioremediation Optimization Test

Final Report
WSRC-MS-96-0797, Rev. 0

Jan. 24, 1997

\section{Appendix 1 (cont'd)}

\begin{tabular}{|c|c|c|c|c|c|c|c|c|c|}
\hline Piezometer & Status & Campaign & Date & Time & $\% \mathrm{CH}_{4}$ & $\% \mathrm{CO}_{2}$ & $\% \mathrm{O}_{2}$ & $\begin{array}{c}\text { Pressure, } \\
\text { " } \mathrm{H} 2 \mathrm{O}\end{array}$ & $\mathrm{O} 2 / \mathrm{CO}_{2}$ \\
\hline 9 & OFF & Baseline & $7 / 8 / 96$ & - & 0 & 7.5 & 9.3 & - & 1.24 \\
\hline 9 & OFF & Baseline & $7 / 18 / 96$ & - & 0 & 14 & 1.3 & 0.2 & 0.09 \\
\hline 9 & OFF & Baseline & $7 / 23 / 96$ & - & 2.1 & 9.3 & 1.3 & 0 & 0.14 \\
\hline 9 & OFF & Baseline & $7 / 30 / 96$ & - & 13.8 & 6.7 & 1.3 & 0 & 0.19 \\
\hline 9 & OFF & Baseline & $8 / 6 / 96$ & - & 0 & 15.5 & 1 & 0 & 0.06 \\
\hline 9 & OFF & Baseline & $8 / 16 / 96$ & - & 1.8 & 9.6 & 1.5 & - & 0.16 \\
\hline 9 & OFF & Baseline & $8 / 21 / 96$ & - & 0 & 14.9 & 1.5 & 0 & 0.10 \\
\hline 9 & OFF & Baseline & $9 / 19 / 96$ & - & 0 & 11.1 & 6 & - & 0.54 \\
\hline 9 & OFF & Baseline & $9 / 21 / 96$ & - & 0 & 11.3. & 6 & 0 & 0.53 \\
\hline 9 & ON & Air & $10 / 6 / 96$ & 935 & 0 & 1 & 19.7 & 0.4 & 19.70 \\
\hline 9 & ON & Air & $10 / 8 / 96$ & 1148 & - & 0.4 & 19.7 & 1.1 & 49.25 \\
\hline 9 & ON & Air & $10 / 9 / 96$ & 1145 & - & 0.3 & 19.9 & 0.9 & 66.33 \\
\hline 9 & ON & Air & $10 / 10 / 96$ & 1237 & 0 & 0.5 & 19.7 & $=$ & 39.40 \\
\hline 9 & ON & Air + TEP & $10 / 24 / 96$ & 916 & 0 & 1 & 19.8 & 0.2 & 19.80 \\
\hline 9 & ON & Air + TEP & $10 / 30 / 96$ & 1031 & 0 & 1.5 & 19.2 & 0.2 & 12.80 \\
\hline 9 & ON & Air + TEP & $10 / 31 / 96$ & 1043 & 0 & 0.9 & 19.4 & - & 21.56 \\
\hline 9 & ON & Air + TEP & $10 / 31 / 96$ & 1313 & 0 & 0.9 & 19.3 & - & 21.44 \\
\hline 9 & ON & $\mathrm{Air}+\mathrm{N} 2 \mathrm{O}$ & $11 / 12 / 96$ & 908 & 0 & 0.5 & 20.5 & - & 41.00 \\
\hline 9 & $\mathrm{ON}$ & $\mathrm{Air}+\mathrm{N} 2 \mathrm{O}$ & $11 / 15 / 96$ & 1127 & 0 & 0.5 & 19.9 & - & 39.80 \\
\hline 9 & ON & $\mathrm{Air}+\mathrm{CH} 4$ & $11 / 24 / 96$ & 1142 & 0 & 0.4 & 20.3 & 0.4 & 50.75 \\
\hline 9 & ON & $\mathrm{Air}+\mathrm{CH} 4$ & $11 / 24 / 96$ & 1441 & 2.6 & 0.3 & 19.6 & - & 65.33 \\
\hline 9 & ON & $\mathrm{Air}+\mathrm{CH} 4$ & $11 / 27 / 96$ & 1154 & 2.5 & 0.5 & 19.1 & - & 38.20 \\
\hline
\end{tabular}


Appendix 2. Volatile organics in soil gas

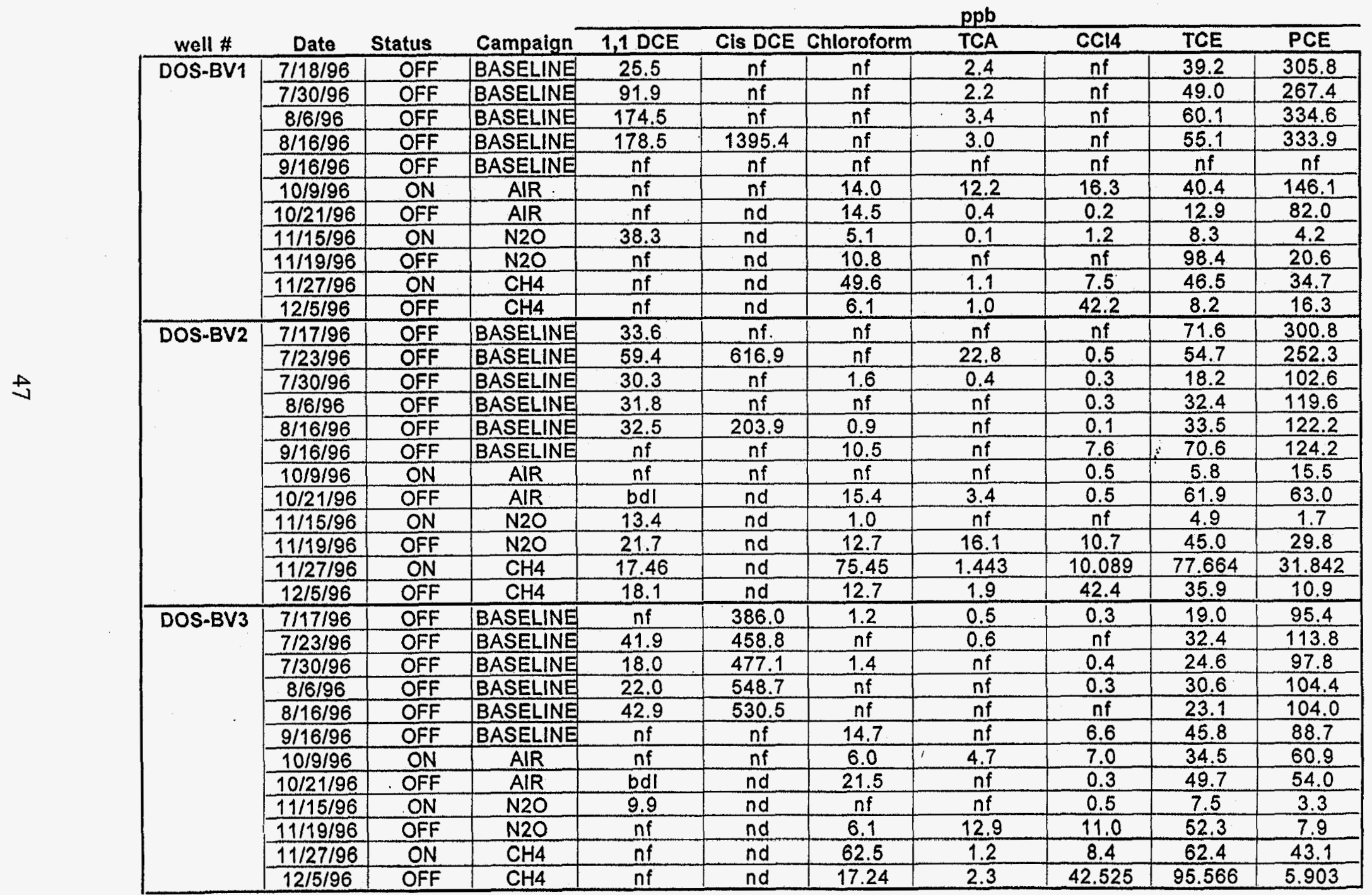


Appendix 2 (cont'd)

\begin{tabular}{|c|c|c|c|c|c|c|c|c|c|c|}
\hline \multirow[b]{2}{*}{ well \# } & \multirow[b]{2}{*}{ Date } & \multirow[b]{2}{*}{ Status } & \multirow[b]{2}{*}{ Campaign } & \multicolumn{7}{|c|}{$\mathrm{ppb}$} \\
\hline & & & & 1,1 DCE & Cis DCE & Chloroform & TCA & $\mathrm{CCl} 4$ & TCE & PCE \\
\hline \multirow[t]{12}{*}{ DOS-BV4 } & $7 / 17 / 96$ & OFF & BASELINE & 63.7 & 471.6 & \begin{tabular}{|c|}
$\mathrm{nf}$ \\
\end{tabular} & 0.6 & 0.2 & 69.2 & 346.5 \\
\hline & $7 / 23 / 96$ & OFF & BASELINE & $n f$ & $\mathrm{nf}$ & $n f$ & 2.6 & $n f$ & 11.6 & 90.1 \\
\hline & $7 / 30 / 96$ & OFF & BASELINE & 74.5 & 279.3 & $n f$ & $\mathrm{nf}$ & 0.3 & 65.8 & 296.4 \\
\hline & $8 / 6 / 96$ & OFF & BASELINE & 87.4 & 443.1 & $n f$ & $n f$ & 0.3 & 68.1 & 287.0 \\
\hline & $8 / 16 / 96$ & OFF & BASELINE & nf & 379.1 & $n f$ & $\mathrm{nf}$ & $n f$ & 63.9 & 308.7 \\
\hline & $9 / 16 / 96$ & OFF & BASELINE & nf & $\mathrm{nf}$ & 11.2 & $n f$ & 8.3 & 52.8 & 188.4 \\
\hline & $10 / 9 / 96$ & $\mathrm{ON}$ & AIR & $n f$ & $\mathrm{nf}$ & $n f$ & $n f$ & 0.6 & 12.6 & 16.0 \\
\hline & $10 / 21 / 96$ & OFF & AIR & bdl & nd & 10.1 & 3.7 & 0.2 & 53.2 & 213.0 \\
\hline & $11 / 15 / 96$ & ON & $\mathrm{N} 2 \mathrm{O}$ & 22.5 & nd & $\mathrm{nf}$ & $\mathrm{nf}$ & $\mathrm{nf}$ & 119.6 & 224.9 \\
\hline & $11 / 19 / 96$ & OFF & $\mathrm{N} 2 \mathrm{O}$ & 16.8 & nd & 9.2 & 0.6 & 1.9 & 99.0 & 229.2 \\
\hline & $11 / 27 / 96$ & $\mathrm{ON}$ & $\mathrm{CH} 4$ & 17.6 & nd & 68.2 & 1.2 & 8.4 & 131.5 & 148.4 \\
\hline & $12 / 5 / 96$ & OFF & $\mathrm{CH} 4$ & $\mathrm{nf}$ & nd & 12.7 & 1.4 & 42.4 & 64.7 & 191.9 \\
\hline \multirow[t]{12}{*}{ DOS-BV5 } & $7 / 17 / 96$ & OFF & BASELINE & 32.4 & $n f$ & $n f$ & $\mathrm{nf}$ & $n f$ & 21.0 & 205.4 \\
\hline & $7 / 23 / 96$ & OFF & BASELINE & 50.3 & 364.8 & $n f$ & 2.8 & 0.1 & 11.9 & 141.7 \\
\hline & $7 / 30 / 96$ & OFF & BASELINE & 22.6 & $\mathrm{nf}$ & 1.3 & 0.8 & 0.4 & 10.4 & 95.6 \\
\hline & $8 / 6 / 96$ & OFF & BASELINE & 48.1 & 400.5 & 0.6 & 0.4 & 0.2 & 13.8 & 133.9 \\
\hline & $8 / 16 / 96$ & OFF & BASELINE & 97.8 & 764.5 & 4.1 & 2.3 & 0.4 & 50.8 & 319.1 \\
\hline & $9 / 16 / 96$ & OFF & BASELINE & $\mathrm{nf}$ & $\mathrm{nf}$ & 15.5 & $n f$ & 9.8 & 36.3 & 92.4 \\
\hline & $10 / 9 / 96$ & ON & AIR & $\mathrm{nf}$ & $\mathrm{nf}$ & 5.0 & 2.4 & 4.4 & 29.5 & 46.5 \\
\hline & $10 / 21 / 96$ & OFF & AIR & bdl & nd & 12.1 & 0.5 & 0.2 & 18.1 & 42.0 \\
\hline & $11 / 15 / 96$ & ON & $\mathrm{N2O}$ & $n f$ & nd & $\mathrm{nf}$ & $\mathrm{nf}$ & $n f$ & 2.2 & 0.4 \\
\hline & $11 / 19 / 96$ & OFF & $\mathrm{N} 2 \mathrm{O}$ & 20.2 & nd & 11.2 & 1.5 & 5.8 & 26.7 & 17.6 \\
\hline & $11 / 27 / 96$ & $\mathrm{ON}$ & $\mathrm{CH} 4$ & 20.4 & nd & 83.6 & 1.5 & 10.1 & 70.0 & 37.6 \\
\hline & $12 / 5 / 96$ & OFF & $\mathrm{CH} 4$ & 23.0 & nd & 11.6 & 1.8 & 42.4 & 18.2 & 21.0 \\
\hline \multirow[t]{12}{*}{ DOS-BV6 } & $7 / 17 / 96$ & OFF & BASELINE & 24.8 & $n f$ & 2.2 & 0.6 & 0.3 & 6.8 & 146.3 \\
\hline & $7 / 23 / 96$ & OFF & BASELINE & 62.8 & $\mathrm{nf}$ & $n f$ & 0.5 & 0.1 & 8.7 & 171.9 \\
\hline & $7 / 30 / 96$ & OFF & BASELINE & 25.7 & $n f$ & 2.5 & $n f$ & 0.4 & 7.6 & 153.1 \\
\hline & $8 / 6 / 96$ & OFF & BASELINE & 37.0 & $n f$ & 1.6 & $n f$ & 0.3 & 8.9 & 162.6 \\
\hline & $8 / 16 / 96$ & OFF & BASELINE & $\mathrm{nf}$ & $n f$ & 1.7 & $n f$ & 0.2 & 9.2 & 177.6 \\
\hline & $9 / 16 / 96$ & OFF & BASELINE & $n f$ & $n f$ & 15.1 & $n f$ & 7.0 & 28.9 & 159.9 \\
\hline & $10 / 9 / 96$ & $\mathrm{ON}$ & AIR & $n f$ & $\mathrm{nf}$ & $n f$ & $n f$ & $n f$ & 2.0 & 16.2 \\
\hline & $10 / 21 / 96$ & OFF & AlR & nd & nd & 33.3 & $\mathrm{nf}$ & 0.4 & 20.7 & 101.0 \\
\hline & $11 / 15 / 96$ & $\mathrm{ON}$ & $\mathrm{N2O}$ & 483.4 & nd & $n f$ & $n f$ & $\mathrm{nf}$ & $n f$ & 4.4 \\
\hline & $11 / 19 / 96$ & OFF & $\mathrm{N} 2 \mathrm{O}$ & $\mathrm{nf}$ & nd & 14.7 & 0.8 & 4.0 & 25.3 & 72.1 \\
\hline & $11 / 27 / 96$ & $\mathrm{ON}$ & $\mathrm{CH} 4$ & $\mathrm{nf}$ & nd & 63.1 & 1.2 & 42.5 & 60.5 & 95.3 \\
\hline & $12 / 5 / 96$ & OFF & $\mathrm{CH} 4$ & 21.7 & nd & 70.8 & 10.1 & 44.5 & 43.1 & 25.5 \\
\hline
\end{tabular}




\section{Appendix 2 (cont'd)}

\begin{tabular}{|c|c|c|c|c|c|c|c|c|c|c|}
\hline \multirow{2}{*}{ well \# } & \multirow[b]{2}{*}{ Date } & \multirow[b]{2}{*}{ Status } & \multirow[b]{2}{*}{ Campaign } & \multicolumn{7}{|c|}{ ppb } \\
\hline & & & & 1,1 DCE & Cis DCE & Chloroform & TCA & $\mathrm{CCl} 4$ & TCE & PCE \\
\hline \multirow[t]{12}{*}{ DOS-BV7 } & $7 / 17 / 96$ & OFF & BASELINE & 213.4 & 1850.5 & 3.1 & 2.9 & 0.3 & 2516.6 & 1186.8 \\
\hline & $7 / 23 / 96$ & OFF & BASELINE & 221.5 & 1979.6 & 2.6 & 2.9 & 0.2 & 2531.0 & 1207.2 \\
\hline & $7 / 30 / 96$ & OFF & BASELINE & 204.7 & 2028.2 & 3.1 & 2.2 & 0.4 & 2185.9 & 1138.2 \\
\hline & $8 / 6 / 96$ & OFF & BASELINE & 199.6 & 2073.3 & 2.6 & 3.1 & $n f$ & 2300.4 & 1183.2 \\
\hline & $8 / 16 / 96$ & OFF & BASELINE & $\mathrm{nf}$ & 2551.5 & $n f$ & $\mathrm{nf}$ & 0.3 & 1226.2 & 1218.6 \\
\hline & $9 / 16 / 96$ & OFF & BASELINE & 328.0 & 2486.2 & 16.0 & $\mathrm{nf}$ & 7.4 & $n f$ & 1366.6 \\
\hline & $10 / 9 / 96$ & ON & AIR & $\mathrm{nf}$ & $n f$ & $\mathrm{nf}$ & $n f$ & $n f$ & 222.5 & 191.6 \\
\hline & $10 / 21 / 96$ & OFF & AIR & 18.3 & nd & 15.0 & 3.0 & 0.3 & 4607.9 & 2166.0 \\
\hline & $11 / 15 / 96$ & ON & $\mathrm{N} 2 \mathrm{O}$ & 75.6 & nd & 2.6 & $n f$ & 1.7 & 578.5 & 597.7 \\
\hline & $11 / 19 / 96$ & OFF & $\mathrm{N} 2 \mathrm{O}$ & 33.9 & nd & 15.9 & 0.7 & 3.2 & 1442.2 & 1820.0 \\
\hline & $11 / 27 / 96$ & $\mathrm{ON}$ & $\mathrm{CH} 4$ & 27.7 & nd & 110.8 & 2.9 & 10.7 & 507.3 & 382.1 \\
\hline & $12 / 5 / 96$ & OFF & $\mathrm{CH} 4$ & 41.872 & nd & 12.386 & 1.787 & 42.553 & 1114.705 & 1513.72 \\
\hline \multirow[t]{11}{*}{ DOS-BV 8} & $7 / 18 / 96$ & OFF & BASELINE & 42.3 & nf & $n f$ & $n f$ & $n f$ & 12.3 & 121.6 \\
\hline & $7 / 30 / 96$ & OFF & BASELINE & 55.5 & $n f$ & 1.6 & $\mathrm{nf}$ & 0.3 & 12.2 & 122.6 \\
\hline & $8 / 6 / 96$ & OFF & BASELINE & 27.7 & $n f$ & 1.8 & 0.3 & 0.2 & 11.1 & 122.8 \\
\hline & $8 / 16 / 96$ & OFF & BASELINE & $n f$ & $n f$ & 1.1 & $\mathrm{nf}$ & 0.1 & 9.8 & 142.3 \\
\hline & $9 / 16 / 96$ & OFF & BASELINE & $n f$ & $n f$ & 15.4 & $n f$ & 7.7 & 28.0 & 137.9 \\
\hline & $10 / 9 / 96$ & $\mathrm{ON}$ & AIR & $n f$ & nf & $\mathrm{nf}$ & $\mathrm{nf}$ & $n f$ & 3.9 & 14.9 \\
\hline & $10 / 21 / 96$ & OFF & AlR & $n f$ & nd & 18.6 & 0.3 & 0.2 & 19.9 & 83.0 \\
\hline & $11 / 15 / 96$ & ON & $\mathrm{N} 2 \mathrm{O}$ & 15.8 & nd & $\mathrm{nf}$ & $\mathrm{nf}$ & $n f$ & $\mathrm{nf}$ & 13.2 \\
\hline & $11 / 19 / 96$ & OFF & $\mathrm{N} 2 \mathrm{O}$ & $\mathrm{nf}$ & nd & 12.1 & 0.5 & 2.2 & 23.9 & 52.7 \\
\hline & $11 / 27 / 96$ & ON & $\mathrm{CH} 4$ & 22.5 & nd & 144.8 & 2.9 & 11.3 & 86.1 & 52.4 \\
\hline & $12 / 5 / 96$ & OFF & $\mathrm{CH} 4$ & $n f$ & nd & 9.3 & 1.1 & 42.3 & 16.0 & 26.8 \\
\hline \multirow[t]{11}{*}{ DOS-BV9 } & $7 / 18 / 96$ & OFF & BASELINE & 81.9 & $n f$ & 1.6 & 0.2 & 0.3 & 41.3 & 616.0 \\
\hline & $7 / 30 / 96$ & OFF & BASELINE & 79.0 & $n f$ & 2.7 & $\mathrm{nf}$ & 0.5 & 49.1 & 623.0 \\
\hline & $8 / 6 / 96$ & OFF & BASELINE & 62.9 & $n f$ & $\mathrm{nf}$ & $n f$ & 0.3 & 55.9 & 625.4 \\
\hline & $8 / 16 / 96$ & OFF & BASELINE & 58.2 & $n f$ & 1.4 & nf & 0.2 & 49.4 & 636.8 \\
\hline & $9 / 16 / 96$ & OFF & BASELINE & $\mathrm{nf}$ & nf & 16.7 & $n f$ & 8.2 & 68.5 & 544.6 \\
\hline & $10 / 9 / 96$ & $\mathrm{ON}$ & AIR & $\mathrm{nf}$ & $n f$ & $\mathrm{nf}$ & $n f$ & $n f$ & 3.4 & 13.1 \\
\hline & $10 / 21 / 96$ & OFF & AIR & $\mathrm{nf}$ & nd & 30.4 & 0.5 & 0.7 & 38.3 & 326.0 \\
\hline & $11 / 15 / 96$ & ON & $\mathrm{N} 2 \mathrm{O}$ & $n f$ & nd & 2.8 & $\mathrm{nf}$ & $n f$ & 3.9 & 3.7 \\
\hline & $11 / 19 / 96$ & OFF & $\mathrm{N} 2 \mathrm{O}$ & 31.7 & nd & 18.5 & 0.7 & 3.7 & 37.4 & 1.48 .6 \\
\hline & $11 / 27 / 96$ &.$O N$ & $\mathrm{CH} 4$ & 24.2 & nd & 69.9 & 1.2 & 9.7 & 66.5 & 66.6 \\
\hline & $12 / 5 / 96$ & OFF & $\mathrm{CH} 4$ & 26.6 & nd & 10.8 & 1.2 & 42.3 & 20.5 & 84.7 \\
\hline \multirow{2}{*}{$\begin{array}{l}1 \mathrm{HW} 390^{\circ} \\
2 \mathrm{HW} 390^{\circ}\end{array}$} & $9 / 15 / 96$ & OFF & & $n f$ & $n f$ & $n f$ & $\mathrm{nf}$ & $n f$ & $n f$ & $n f$ \\
\hline & $9 / 15 / 96$ & OFF & & $n f$ & $n f$ & $n f$ & $\mathrm{nf}$ & nf & 758.3 & 1208.7 \\
\hline
\end{tabular}

nd - not determined (calibration standard not available or not detectable) nf - peak not found in sample

bdl - peak found but below detection limits 


\section{Appendix 3. Soil surface emissions}

- 1302 Measurement Data 1732827/2803 - 1996-12-05 14:50 - Page 1 1302 Settings:

Compensate for Water Vap. Interference

Compensate for Cross Interference :

Sample Continuously

Sampling Interval

Pre-set Monitoring Period : NO

Measure

Gas A: PCE

$: \quad$ YES

Gas B: TCE

Gas C: Vinyl chloride

: YES

Gas D: $\mathrm{CO} 2$

$\begin{array}{ccc}: & \text { YES } \\ : & \text { YES } \\ : & \text { YES } \\ : & \text { YES }\end{array}$

Water Vapour

Sampling Tube Length

Air Pressure

$$
\text { : } \quad 2.0 \mathrm{ft}
$$

Normalization Temperature $\quad: \quad 20.0 \mathrm{C}$

General Information:

Start Time

: 1996-12-04 14:02

Stop Time : 1996-12-04 16:19

Results Not Averaged

Number of Event Marks

Number of Recorded Samples

$\begin{array}{ll}: & 0 \\ : \quad 28\end{array}$

\begin{tabular}{llcccc} 
& Alarm Limit & Max & Mean & Min & Std.Dev \\
\hline Gas A: & & $278 \mathrm{E}-03$ & $-250 \mathrm{E}-03$ & $-410 \mathrm{E}-03$ & $133 \mathrm{E}-03$ \\
Gas B: & $21.6 \mathrm{E}-03$ & $-110 \mathrm{E}-03$ & $-265 \mathrm{E}-03$ & $75.2 \mathrm{E}-03$ \\
Gas C: & $2.95 \mathrm{E}+00$ & $2.34 \mathrm{E}+00$ & $1.33 \mathrm{E}+00$ & $386 \mathrm{E}-03$ \\
Gas D: & - & $851 \mathrm{E}+00$ & $649 \mathrm{E}+00$ & $373 \mathrm{E}+00$ & $138 \mathrm{E}+00$ \\
Gas E: & $733 \mathrm{E}-03$ & $590 \mathrm{E}-03$ & $485 \mathrm{E}-03$ & $74.6 \mathrm{E}-03$ \\
Water: & $16.3 \mathrm{E}+00$ & $13.9 \mathrm{E}+00$ & $479 \mathrm{E}-03$ & $3.24 \mathrm{E}+00$
\end{tabular}


Appendix 3 (cont'd)

- 1302 Measurement Data ------ 1732827/2803 - 1996-12-05 14:50 - Page 2 -

Samples Measured From 1996-12-04 14:02

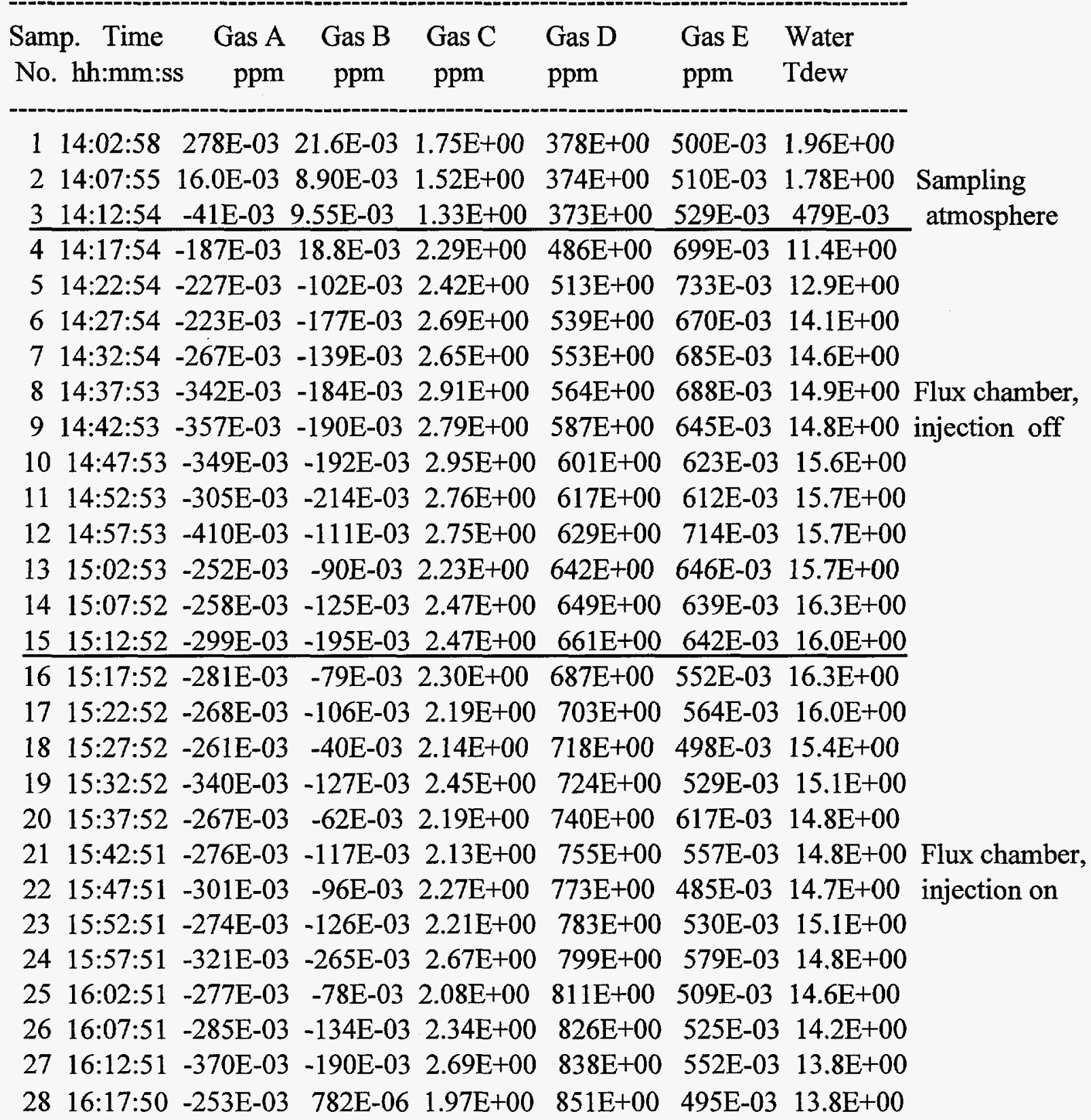

